Florida International University FIU Digital Commons

\title{
Contemporary Aspects of Dividends: Before and During the Financial Crisis
}

Gizelle Fernandez Perretti

Florida International University, gizelle.perretti@gmail.com

DOI: $10.25148 /$ etd.FI1 1080401

Follow this and additional works at: https://digitalcommons.fiu.edu/etd

\section{Recommended Citation}

Fernandez Perretti, Gizelle, "Contemporary Aspects of Dividends: Before and During the Financial Crisis" (2011). FIU Electronic Theses and Dissertations. 451.

https://digitalcommons.fiu.edu/etd/451 


\section{FLORIDA INTERNATIONAL UNIVERSITY \\ Miami, Florida}

CONTEMPORARY ASPECTS OF DIVIDENDS: BEFORE AND DURING THE

FINANCIAL CRISIS

A dissertation submitted in partial fulfillment of the

requirements for the degree of

DOCTOR OF PHILOSOPHY

in

BUSINESS ADMINISTRATION

By

Gizelle Fernandez Perretti 
To: Dean Joyce Elam

College of Business Administration

This dissertation, written by Gizelle Fernandez Perretti, and entitled Contemporary Aspects of Dividends: Before and During the Financial Crisis, having been approved in respect to style and intellectual content, is referred to you for judgment.

We have read this dissertation and recommend that it be approved.

Arun J. Prakash

Chun-Hao Chang

Gauri Ghai

Ali M. Parhizgari, Major Professor

Date of Defense: July 14, 2011

The dissertation of Gizelle Fernandez Perretti is approved.

Dean Joyce Elam

College of Business Administration

Dean Lakshmi N. Reddi

University Graduate School

Florida International University, 2011 
(C) Copyright 2011 by Gizelle Fernandez Perretti All rights reserved. 


\section{ACKNOWLEDGMENTS}

I wish to express by deepest thanks to my dissertation chair Dr. Ali M. Parhizgari. His support and guidance as I progressed with my dissertation was invaluable. Without his assistance, this work would not have been possible. I also wish to express my appreciation for my committee members, Dr. Arun Prakash, Dr. Chun-Hao Chang, and Dr. Gauri Ghai, for their help and guidance. I am also grateful to the faculty and staff of the Department of Finance and Real Estate for their support and encouragement throughout my Ph.D. studies.

I wish to express my deep appreciation for my family and friends for all their support, patience, and love. I wish to thank Joseph Perretti for his love, understanding, and support. I would also like to thank Bubba and Jesse for their undying playfulness and joy when I need it the most. I will forever be grateful to my parents, Jose and Marbella Fernandez: my mother, for always consoling me when things are difficult; and my father for being a great leader, for always encouraging me to go beyond my fears and doubts, and for accepting nothing less than my very best. 


\title{
ABSTRACT OF THE DISSERTATION \\ CONTEMPORARY ASPECTS OF DIVIDENDS: BEFORE AND DURING THE FINANCIAL CRISIS
}

by

\author{
Gizelle Fernandez Perretti
}

Florida International University, 2011

Miami, Florida

\section{Professor Ali M. Parhizgari, Major Professor}

The number of dividend paying firms has been on the decline since the popularity of stock repurchases in the 1980 s, and the recent financial crisis has brought about a wave of dividend reductions and omissions. This dissertation examined the U.S. firms and American Depository Receipts that are listed on the U.S. equity exchanges according to their dividend paying history in the previous twelve quarters. While accounting for the state of the economy, the firm's size, profitability, earned equity, and growth opportunities, it determines whether or not the firm will pay a dividend in the next quarter. It also examined the likelihood of a dividend change. Further, returns of firms were examined according to their dividend paying history and the state of the economy using the Fama-French three-factor model.

Using forward, backward, and step-wise selection logistic regressions, the results show that firms with a history of regular and uninterrupted dividend payments are likely to continue to pay dividends, while firms that do not have a history of regular dividend payments are not likely to begin to pay dividends or continue to do so. The results of a set of generalized polytomous logistic regressions imply that dividend paying firms are more 
likely to reduce dividend payments during economic expansions, as opposed to recessions. Also the analysis of returns using the Fama-French three factor model reveals that dividend paying firms are earning significant abnormal positive returns.

As a special case, a similar analysis of dividend payment and dividend change was applied to American Depository Receipts that trade on the NYSE, NASDAQ, and AMEX exchanges and are issued by the Bank of New York Mellon. Returns of American Depository Receipts were examined using the Fama-French two-factor model for international firms. The results of the generalized polytomous logistic regression analyses indicate that dividend paying status and economic conditions are also important for dividend level change of American Depository Receipts, and Fama-French two-factor regressions alone do not adequately explain returns for these securities. 


\section{TABLE OF CONTENTS}

CHAPTER $\quad$ PAGE

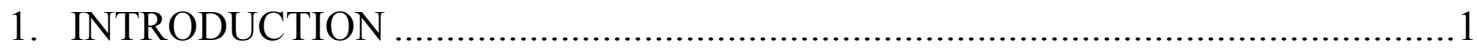

1.1. General Introduction to Dividends ..........................................................

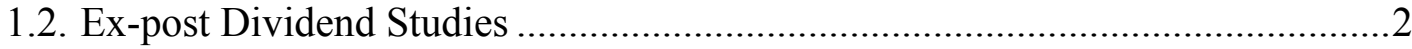

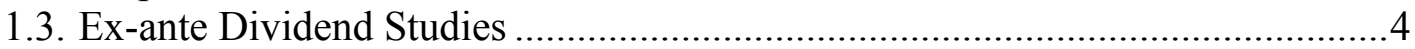

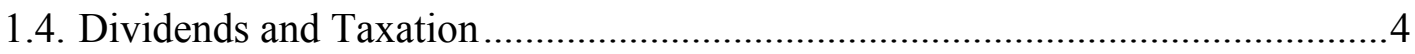

1.5. Dividends, Governance and Agency Theory ...................................................

1.6. Dividends and Retained Earnings: Growth and Financing New Projects or Extending Current Projects...........................................................................

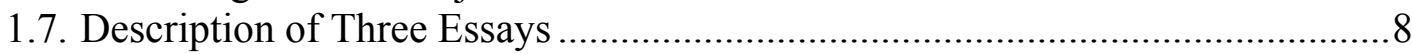

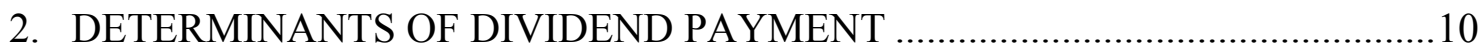

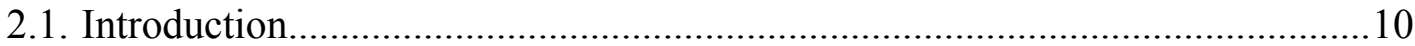

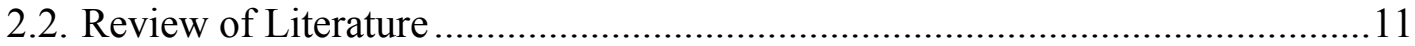

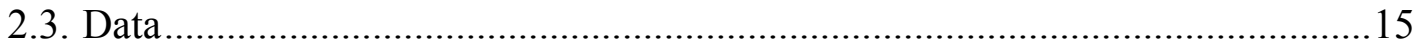

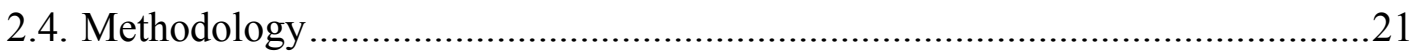

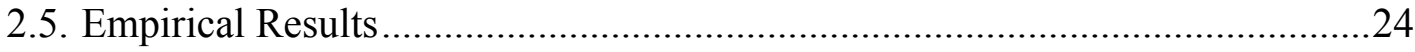

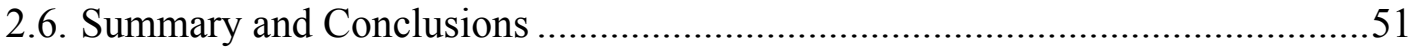

3. DETERMINANTS OF DIVIDEND INCREASES OR DECREASES

OF US STOCKS AND THE EFFECTS ON RETURNS …………......................53

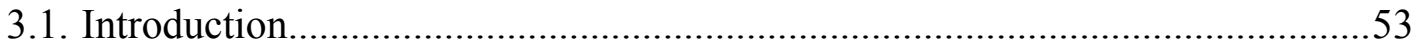

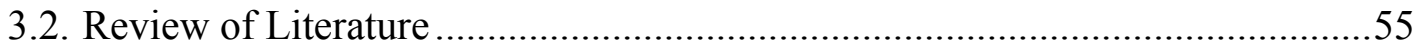

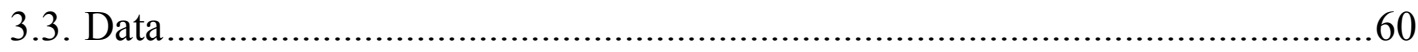

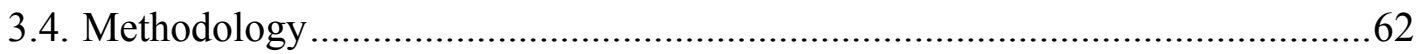

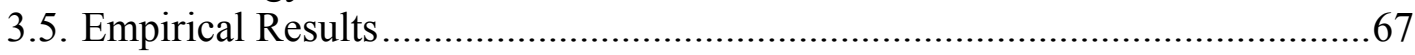

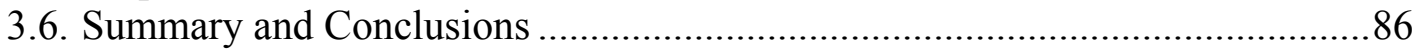

4. DETERMINANTS OF DIVIDEND INCREASES OR DECREASES

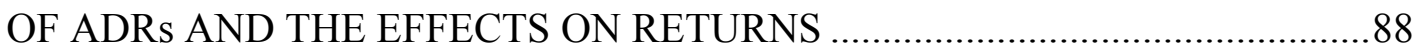

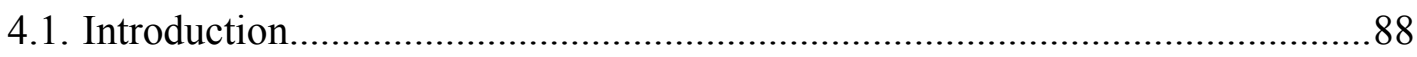

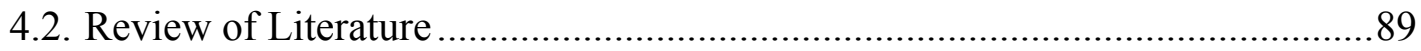

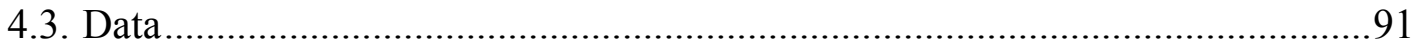

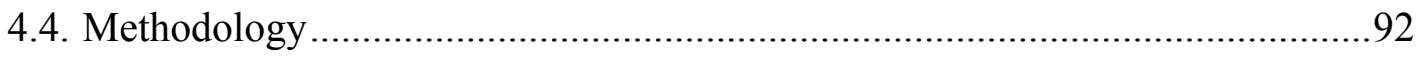

4.5. Empirical Results ........................................................................................97

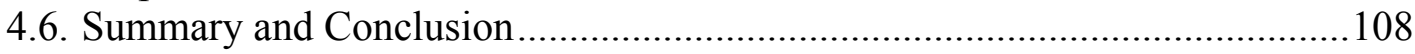

5. FINAL SUMMARY AND CONCLUSIONS ……….....................................110

5.1. Summary of Empirical Findings................................................................. 110

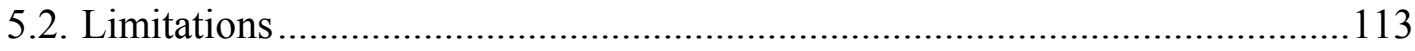

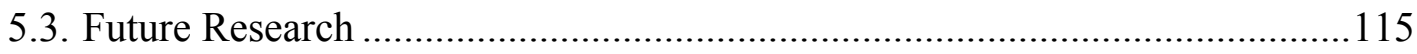

5.4. Concluding Remarks ...............................................................................115 


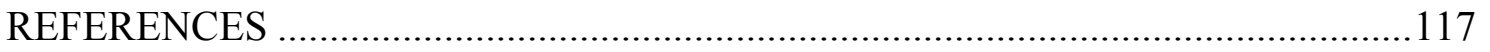

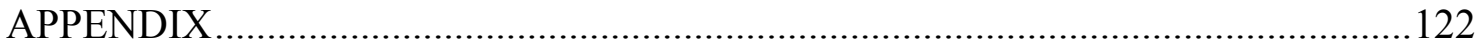

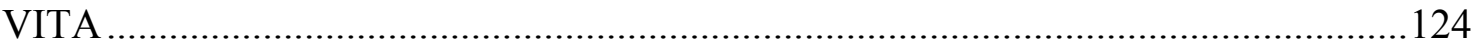




\section{LIST OF TABLES}

TABLE

PAGE

1. Descriptive Statistics for Non-Dividend Paying, Dividend Paying, and Switcher Firms, 1993Q1 - 2009Q2

2. Univariate Statistics According to Dividend Paying Status and Economic Cycle .....22

3. Number of Instances when Firms Paid or Did Not Pay a Dividend According to Dividend Paying Status and Economic Cycle

4. Forward Selection Procedure With Growth Opportunities 1 and Profitability 1 and NBER Market Measure.

5. Forward Selection Procedure With Growth Opportunities 1 and Profitability 1 and GDP Market Measure

6. Forward Selection Procedure With Growth Opportunities 1 and Profitability 1 and S\&P 500 Market Measure

7. Forward Selection Procedure With Growth Opportunities 2 and Profitability 2 and NBER Market Measure.

8. Forward Selection Procedure With Growth Opportunities 2 and Profitability 2 and GDP Market Measure

9. Forward Selection Procedure With Growth Opportunities 2 and Profitability 2 and S\&P 500 Market Measure.

10. Stepwise Selection Procedure With NBER Market Measure

11. Number of Dividend Changes (1993Q1 - 2009Q2)....

12. Number of Dividend Changes Over Time (1993Q1 - 2009Q2).....

13. Summary Statistics of Dividend Payment Level, Change, and Percentage Change ..69

14. Average Dividend Payment Level, Change, and Percentage Change 70

15. Summary Statistics of Dividend Determinants According to Dividend Paying Status.

16. Summary Statistics of Dividend Determinants According to Dividend Paying Status and Economic Cycle ..... 
17. Generalized Logarithmic Regression With Growth Opportunities 1 and Profitability 1 and NBER Market Measure

18. Summary Statistics: Excess Return, Market Value and Book-to-Market Ratio by Dividend-Paying Status (1993 - 2009)

19. Summary Statistics: Excess Return, Market Value and Book-to-Market Ratio by Dividend-Paying Status and Time (1993 - 2009)

20. Fama-French Three Factor Regressions by Dividend-Paying Status (1993-2009) ....82

21. Fama-French Three Factor Regressions by Dividend-Paying Status and Time (1993-2009).

22. Descriptive Statistics for Dividend Changes and Associated Returns. .85

23. Number of Dividend Changes, ADRs (1993Q1 - 2009Q2)....

24. Number of Dividend Changes Over Time, ADRs (1993Q1 - 2009Q2)....

25. Summary Statistics of Dividend Payment Level, Change, and Percentage Change, ADRs .96

26. Summary Statistics of Dividend Determinants According to Dividend Paying Status, ADRs

27. Summary Statistics of Dividend Determinants According to Dividend Paying Status and Economic Cycle, ADRs

28. Generalized Logarithmic Regressions with Growth Opportunities 1 and Profitability 1, ADRs

29. Fama-French Three Factor Regressions by Dividend-Paying Status, ADRs (1993-2009). 106

30. Fama-French Three Factor Regressions by Dividend-Paying Status and Dividend Change, ADRs (1993-2009)

31. Fama-French Three Factor Regressions by Dividend-Paying Status and Economic Cycle, ADRs (1993-2009) 108 


\section{CHAPTER 1: INTRODUCTION}

\subsection{General Introduction to Dividends}

Although previous studies have identified a decline in the number of firms that distribute dividends, many firms continue to pay them. From 1990 through 2009, 111 firms paid a regular, quarterly, cash dividend in every quarter. That is a relatively small number of firms, yet the consistency exemplifies that regular quarterly dividends are important to investors, despite the triviality assigned to dividends by previous literature. The large body of literature on dividends also attests to their importance.

In the past, dividend studies largely concentrated on the dividend-earnings relationship. For example, DeAngelo, DeAngelo, and Skinner (1992) examine the relation between earnings and dividends. Among other things, they highlight the great reduction in dividends followed by losses in earnings and earnings difficulties. Past earnings problems are also related to dividend omissions. Of the firms examined in DeAngelo, DeAngelo, and Skinner (1992), 15\% of negative earners omitted dividends.

After the 1990s, dividend related studies began to document declines in dividend paying firms. This trend was initially documented by Fama and French (2001). Skinner (2008) found that firms who only pay dividends (without making any repurchases) declined from $13 \%$ in 1980 to $7 \%$ in 2005 . A decline in earnings, as well as an increase in the volatility of earnings has also been documented (Skinner, 2008). DeAngelo, DeAngelo, and Stulz (2006) point out that only $11.8 \%$ of firms reported negative earnings in 1978, while 50.2\% of firms reported negative earnings in 2002. Despite the decline in the number of dividend paying firms, the amount paid in dividends has 
increased. Firms that do pay dividends have increased the dividend amount over time (DeAngelo, DeAngelo, and Skinner, 2004).

More recent studies have found that the dividend-earnings relationship has weakened. Rather than examine the direct relation between dividends and future earnings, DeAngelo, DeAngelo, and Stulz (2006) examine the relation between earned equity and dividends. They argue that this long term measure of profitability is better than a short term measure in determining the propensity to pay dividends. Using this measure, their results indicate that dividend payment is more likely following increases in earned equity.

Stock repurchases have become the new dividend. Rather than being committed to traditional cash dividends, firms repurchase shares as a way of distributing earnings. Although the relation between dividends and earnings has weakened, Skinner (2008) points out that a strong relationship between repurchases and earnings now exists. In effect, repurchases have replaced dividends.

\subsection{Ex-post Dividend Studies}

Most studies related to dividends are ex-post studies. Ex-post studies examine past data and discuss future implications. Examples of these studies include those mentioned in the above sub-section. For example DeAngelo, DeAngelo, and Skinner (1992) relate current losses to dividend reductions. DeAngelo, DeAngelo, and Stulz (2006) relate earned equity to the propensity to pay dividends. Skinner (2008) relates past earnings to current repurchases and regular dividends. None of these studies use dividends as a predictor for future variables. 
Many dividend paying studies focus on ex-dividend days. The ex-dividend day is the day which determines who receives the dividend. The individual who owns or purchases the share on the ex-dividend day will be the owner of record on the record date. This is the party who receives the dividend, even if the share is sold before the dividend payment day. Theory suggests that the price of the share will increase in an amount equal to the dividend in the days leading up to the ex-dividend day. After the exdividend day, the price of the share will decrease in an amount equal to the dividend. Studies on this topic attempt to measure whether dividends are in fact recaptured. What they find, for the most part, is that the change in the price of the stock is less than the amount of the dividend. Attempts to link the difference are common in dividend literature. Most studies link the difference to transaction costs, taxes, and other market frictions (Campbell and Beranek (1995), Boyd and Jagannathan (1994), and Elton, Gruber, and Blake (2005)). Ex-dividend day studies have even been extended to international firms. Gorman, Mahajan, and Weigand (2004) examine the ex-dividend behavior of American Depository Receipts.

Other dividend studies explore microstructure issues. For example, Graham, Koski, and Loewenstein (2006) study information flow and liquidity surrounding dividend announcements. They find that anticipated dividend announcements are followed by a short term increase in volume and liquidity. Adverse selection and price volatility are not affected by anticipated dividend announcements. This is consistent with previous microstructure models. However, anticipated announcements of important consequence do experience adverse information effects, with spreads remaining wide for a significant period of time. Although unanticipated dividend announcements do not 
exhibit adverse information effects and price volatility long after the announcement, they are associated with wide spreads, less depth, and increased volume. This implies that dividend changes may signal fundamental firm changes.

\subsection{Ex-ante Dividend Studies}

Ex-ante studies on the topic of dividends are rare. These studies relate dividends with variables in the future, unlike the ex-post studies mentioned above.

Miller and Modigliani have authored a few ex-ante dividend studies. Miller and Modigliani (1961) and Modigliani and Miller (1959) relate dividend payment to future earnings. They introduce the "information content of dividends" hypothesis and posit that firms with temporary earnings losses are less likely to reduce dividends, compared to firms with permanent earnings problems.

Another example of this type of study is Parhizgari's working paper "Dividends, taxes, and global financial meltdown.” This paper considers ex-ante effects by linking dividend payments and the effects of variables on payments with potential future variables, as opposed to past variables.

\subsection{Dividends and Taxation}

The controversy surrounding dual taxation of dividends has long been part of dividend literature. Income is taxed at the corporate level, and dividends to shareholders are paid from the firm's after-tax income. Income taxes are once again applied to the dividend cash flows as part of the shareholder's income. This is known as the dual taxation problem. Modigliani and Miller (1958 and 1963) address the dual taxation problem in terms of the optimal dividend payment policy and conclude that because dividends are taxed twice, financing with debt is optimal and firms should not distribute 
dividends. They concede, however, that firms should not attempt to finance the maximum amount possible with debt because at times the cost of capital is still less expensive when dual taxation is considered.

This issue is also examined by Black (1976). Given Miller and Modigliani's (1961) conclusions that dividend policy is irrelevant, he argues that because dividends are taxed twice, the optimal dividend policy is no dividend policy.

DeAngelo and DeAngelo (2006) point out that dividend policy matters whether or not market frictions, such as taxes, exist. The reason for this is one of the fundamental theories of finance: The value (or present value) of a firm depends on the value of its future cash flows. If firms were to do away with dividends, they would, in effect, be doing away with cash flows, and thereby, driving down the present value of the firm and stockholder wealth.

\subsection{Dividends, Governance, and Agency Theory}

Management determines the dividend payout policy of the firm. They elect the amount of the dividend as well as the timing of the distributions. It should also be noted that U.S. companies predominately have dispersed ownership. This means that management is a separate party from ownership. That being the case, dividend distribution policies are affected by governance and agency theory issues.

One of the main theories for explaining why firms pay dividends, despite their unfavorable tax treatment and reduction of retained earnings, is the clientele theory. This theory states that firms pay dividends in order to attract shareholders. They will only do so, when they feel dividends will increase shareholder wealth. 
Another popular and well-studied theory for explanation of dividend distributions is the signaling theory. This theory states that because managers are insiders, they are well aware of the firm's future cash flows and earnings. Outsiders, however, do not have this information available when valuing the firm. Therefore, managers disseminate information regarding the firm's future prospects through dividend distributions. Studies that examine this theory include Litner (1956), Asquith and Mullins (1983), and Fuller and Blau (2010). "The bird in hand" theory suggests that investors prefer dividends over capital gains. Once a dividend is in place, investors expect that dividend to continue into the future at regular intervals, whereas capital gains can be quite unpredictable.

The third theory that explains dividend distributions is the free cash flow hypothesis (Jensen, 1986). This theory compliments agency theory in the governance literature. It states that firms that distribute dividends do so because they have excessive stock piles of cash. Excess cash allows managers more discretion. Agency theory states that managers' interests tend to conflict with shareholder interests. Therefore, shareholders may not be comfortable with large amounts of free cash flow. That being the case, they demand free cash flow be distributed in terms of dividends.

La Porta, Lopez-de-Silanes, Shleifer, and Vishny (2000) extend the free cash flow hypothesis to firms in other countries. They find that when minority shareholders have strong legal protection, they pressure management to distribute dividends. In countries where rights of minority shareholders are not adequately protected, shareholders see dividend distributions as a substitute for legal protection. Hence, these shareholders prefer dividends over promising investment opportunities the firm may otherwise have. 
1.6. Dividends and Retained Earnings: Growth and Financing New Projects or Extending Current Projects

The Miller and Modigliani papers focus on the idea that investment policy and dividend policy go hand-in-hand. Any part of net income not paid out in dividends is available to firms for reinvestment. However, according to Miller and Modigliani, dividend policy is irrelevant because whether a firm distributes earnings or reinvests them in the firm, the value of the firm is not affected. Their framework is, of course, a frictionless market. The assumptions of Miller and Modigliani's irrelevant dividend policy do not hold in the real world. Firms have to contend with market imperfections and frictions, such as taxes, restrictions, and other costs.

The cost of issuing new stock and restrictions on debt covenants make internal financing appealing. That being the case, some companies would prefer to use retained earnings to finance all projects with a positive net present value. After all promising investment opportunities have been financed, any residual funds are used to pay dividends. This is known as a residual dividend policy.

The problem with a residual dividend policy is that once a firm has established a dividend, investors expect that dividend to continue into future periods, regardless of the earnings available after the firm's optimal capital budget has been met. Managers would have to be sure that residual funds will be relatively stable in the future before initiating a dividend. This applies to dividend increases as well.

As pointed out earlier, recent studies note the increase in earnings losses and the volatility of earnings across the cross-section of U.S. firms. According to Opler, Pinkowitz, Stulz, and Williamson (1999), this is "the main reason that firms experience 
large changes in excess cash." Rather than initiate dividends, firms with volatile earnings and high growth opportunities are more likely to hold large cash balances.

\subsection{Description of Three Essays}

In light of all the above dimensions of dividends, the scope of this dissertation is dividend payment history and economic conditions as determinants of dividend payment for U.S. firms. We also examine whether these two factors determine dividend level changes for U.S. firms and American Depository Receipts. Finally, returns according to dividend paying status are examined for both U.S. firms and ADRs.

The first essay is Chapter 2. It investigates the determinants of dividends and attempts to distinguish regular dividend paying firms from firms that do not pay cash dividends. We especially concentrate on the recent financial crisis to expose any changes in the factors that determine whether a firm pays dividends or not. We also contribute to the literature by investigating the possibility of the state of the economy as a factor in determining dividend payment.

The second essay is Chapter 3. This essay concentrates on the determinants for a change in dividend levels of US based stocks. Previous literature finds that managers rely on past dividend levels to determine dividend distributions, and they are reluctant to increase the dividend for the sake of being conservative. They will only change dividends if they feel current increases in earnings are permanent. They are also reluctant to decrease dividends, for fear of sending a distress signal to investors. Despite this, dividend levels do change, although rarely. Changes (decreases, in particular) were especially highlighted in the financial news after the summer of 2008. We also examine returns associated with announcements of dividend changes. 
The final essay is Chapter 4. It is similar to the second essay in that it also examines the determinants of dividend changes, as well as their effects on returns. However, this essay concentrates on American Depository Receipts. We expect the determinants of dividend changes to be different from those of US based firms, possibly including other factors. As far as we know, this is the first study to examine the determinants of dividend changes of ADRs and their effects on returns.

The fifth and final chapter provides a comprehensive summary and conclusion of the essays. Limitations and possible areas of future research in these topics are also highlighted. These are followed by concluding remarks.

It should be emphasized that each of these essays is self-contained and complete. Each essay has its individual introduction, review of literature, and conclusion. Although the pieces are related, in that they are centered on the topic of dividends, they are considerably different. As these are stand-alone pieces, the literature review in each essay is particular to the issue examined within that essay. Therefore, it is not necessary to provide a general literature review. To that extent, the next chapter moves directly to the first essay. 


\section{CHAPTER 2: DETERMINANTS OF DIVIDEND PAYMENT}

\subsection{Introduction}

The recent market downturn was followed by announcements of firms reducing or suspending dividends. Previous literature has attempted to identify factors that determine whether a firm pays dividends or not.

Recent studies find evidence of cash dividend payments disappearing (Fama and French, 2001; DeAngelo, DeAngelo, and Skinner, 2000). Reasons for the declining number of dividend paying firms include the higher volatility of earnings, increases in frequency and magnitude of losses, and an increase in new listings (Hayn, 1995; Fama and French, 2000).

Firms that still pay dividends tend to be large and profitable (Fama and French, 2001). DeAngelo, DeAngelo, and Stulz (2006) detect a positive relation between profitability and the propensity to pay dividends. Denis and Obosov (2008) also find a positive relation between the probability of paying dividends and profitability, as well as firm size.

Reasons for paying dividends are not unanimously agreed upon in the literature. Three theories as to why firms pay dividends exist: the catering theory, the lifecycle theory, and the signaling theory. Until recently, these theories were competing theories. Fuller and Blau (2010) are able to reconcile the lifecycle theory and the signaling theory. They conclude that profitable firms with excess cash tend to pay dividends, but firms that are healthy, yet intermediate performers pay even higher dividends in order to signal that they are healthy firms. 
The determinants of dividend payment identified by previous research as well as the results and conclusions in Fuller and Blau (2010) are of interest considering the recent developments in the economy. The NBER concluded that in December 2007, the United States entered a recession. In the months that followed, news reports announced various firm financial problems, dividend reductions, dividend suspensions, bank takeovers, and the downfall of many prominent firms. Have the determinants that Denis and Obosov (2008) identified changed? Did healthy firms attempt to signal by paying dividends even after the market downturn?

This study attempts to answer those questions by identifying dividend paying determinants before and during the market downturn. The remainder of this chapter is organized as follows: Section 2.2 reviews the previous literature associated with dividend distributions and determinants. Section 2.3 discusses the data available for our study. Section 2.4 discusses the methodology. Section 2.5 discusses the results, and Section 2.6 summarizes and concludes.

\subsection{Literature Review}

One of the fundamental valuation techniques taught in finance courses is Gordon's Dividend Growth Model. According to this model, we can determine the present value of common stock by discounting the future dividends of the firm in question. It would seem then, that firms would distribute dividends regularly, but as recent literature points out, regular dividend paying firms have substantially declined in numbers (Fama and French, 2001; DeAngelo, DeAngelo, and Skinner, 2000). Using data on publicly listed U.S. firms from the Compustat database for the period between 1980 and 2005, Skinner (2008) finds that only 345 firms paid regular dividends. The data 
shows that the number of firms that only pay dividends (make no repurchases) fell from $13 \%$ to $7 \%$ of firms (p 583).

The literature has attempted to link the probability of paying dividends to various firm specific factors. Some argue that a large share of minority shareholders increases the probability of dividend payments (La Porta, Lopez-de-Silanes, Shleifer, and Vishny, 2000). Others point to a positive relation between earnings and dividends (DeAngelo, DeAngelo, and Skinner, 1992). Firm size has also been found to be positively related to dividend payments (Fama and Fernch, 2001; DeAngelo, DeAngelo, and Stulz, 2006; Denis and Obosov 2008). In the Brav, Graham, Harvey, and Michaely (2005) survey, firm mangers admit that past dividend levels, not target dividend ratios, are used in determining the firm's dividend distribution policy. Firms that regularly pay dividends continue to do so because they have a long history of doing so, and therefore feel an obligation to regularly distribute dividends.

Theories that relate to the propensity to pay dividends include the catering or clientele theory, the cash flow or life cycle theory, and the signaling theory. Support and evidence against each theory exists in the literature.

The catering theory states that the demands of the shareholders influence the company's policies (Baker and Wurlger, 2004). It asserts that firms cater to their investors when determining dividend distribution policies. Support for this theory is evident in La Porta, Lopez-de-Silanes, Shleifer, and Vishny (2000). Li and Lee (2006) extend the study by Baker and Wurgler (2004) by providing some evidence (albeit weak) that managers' decisions regarding dividend increases and decreases are influenced by a dividend premium. They concede that the catering theory cannot fully explain dividend 
policies. The majority of the recent literature refutes the catering theory. For example, most studies note the decline in dividend paying firms, which is evidence that firms are not catering to a particular group of investors.

Skinner (2008) investigates the relationship between earnings and repurchases, and finds that while this relationship has strengthened over time, the relationship between earnings and cash dividends has weakened. He observes that firms that exclusively pay dividends are almost non-existent. Rather than pay regular dividends, many firms make repurchases, probably due to their flexibility. Most firms that still pay regular dividends also use repurchases.

The life cycle theory (sometimes referred to as the cash flow theory) states that mature firms are more likely to pay dividends, while younger firms are not. As firms become mature, they tend to become more profitable, yet they have less growth opportunities, which leaves them with large cash balances. If excess cash is not paid out as dividends, mangers are granted more discretion, which shareholders may not be comfortable with. Therefore, mature firms will distribute dividends to minimize excess cash. On the other hand, young firms tend to be less profitable and have more growth opportunities, so any cash they do have will be utilized for investment and growth.

Fama and French (2001) find evidence to support the life cycle theory. They observe that dividends tend to be paid by profitable firms with low growth rates, while less profitable firms with higher growth rates tend to retain earnings. DeAngelo, DeAngelo, and Stulz (2006) also support the life cycle hypothesis and refute the clientele and signaling theories. They measure profitability as the ratio of retained earnings to total equity and the ratio of retained earnings to total assets, arguing that these longer term 
measures of profitability are better determinants (than short term measures) of the propensity to pay dividends. Using logistic regressions, and controlling size, growth, dividend history, and other factors, they find strong evidence that RE/TE and RE/TA are indeed positively related with the probability of dividend payment.

Denis and Obosov (2008) identify determinants of dividends on an international level. They use data from Worldscope, and the available data limits their study to developed countries. Using a logistic model, they find that the propensity to pay dividends is positively related to size and profitability, but negatively related to growth opportunities. The results in Denis and Obosov (2008) also support the lifecycle or cash flow theory of dividend distributions.

The signaling theory states that firms that pay high dividends do so in order to signal to investors that the firm's future cash flows have increased (Healy and Palepu, 1988). A decrease in dividends should be interpreted as evidence that the firm's future cash flows have decreased (Miller and Rock, 1985). Managers have insider information regarding the firm's future prospects, and they use dividend announcements as a method of providing investors with that information. The non-monotonic relation between earnings and dividends observed in previous studies served as evidence against the signaling theory.

Recently, Fuller and Blau (2010) have been able to provide evidence that reconciles the cash flow and signaling theories. They are able to justify the nonmonotonic relationship between firm performance and dividend payment that previous papers have used to refute the signaling theory. They explain that good performers pay a dividend because they may have excess cash and not enough profitable investment 
opportunities. Poor performers pay small dividends, but intermediate performers show evidence of signaling. Intermediate performers that are actually healthy firms pay dividends higher than dividends of good performers in order to distinguish themselves from unhealthy intermediate performers.

\subsection{Data}

The data for this study is available from the CRSP and COMPUSTAT databases. From the CRSP database we are able to gather dividend record dates for firms trading on the NYSE, AMEX, and NASDAQ exchanges. Firms are identified as dividend payers, non-dividend payers, and "switcher" firms based on their dividend paying history in the previous twelve quarters. Firms identified as dividend payers have paid a regular, quarterly, cash dividend in all of the previous twelve quarters. We identify these distributions using the CRSP database code "1232." Firms that have not paid a single regular, quarterly, cash dividend in the previous twelve quarters are labeled as nondividend payers. Switcher firms are those that paid regular, quarterly, cash dividends within the previous twelve quarters, but did not distribute dividends in every quarter.

Most of our data for this study is available from the COMPUSTAT database. From this database, we gather data on fundamental, firm specific variables that may be used to explain a firm's dividend paying status. Data gathered from the COMPUSTAT database includes firm market value, operating income after depreciation, net income, book value of assets, retained earnings, and book value of equity.

The study period ranges from 1993 through 2009 (covering 19 years), but data is gathered from 1990 through 2009 in order to determine the dividend paying status of each firm as explained above. During our study period, the world markets experienced a 
boom and a small crash due to tech stocks in the early 2000s, as well as a severe recession (which began in December 2007, according to NBER) that may have affected dividend paying status. We attempt to find changes in dividend paying status associated with these events, by including a variable to control for the state of the economy. Such a variable can be proxied by various measures, such as the S\&P 500 Index, GDP, and NBER classifications of economic expansions and contractions.

In order to assess whether the market conditions influence dividend payment, we examine these three different indicators of market conditions.

The definition of a recession is two or more consecutive quarters of a decline in GDP. Data on GDP is available from the Bureau of Economic Analysis. This measure may not be satisfactory to some because it does not factor in other items such as unemployment and other market conditions.

The NBER uses a more broadly defined measure of recession. "The NBER does not define a recession in terms of two consecutive quarters of decline in real GDP. Rather, a recession is a significant decline in economic activity spread across the economy, lasting more than a few months, normally visible in real GDP, real income, employment, industrial production, and wholesale-retail sales" (US Business Cycles and Contractions, NBER). According to the NBER, economic contractions in the United States include the time period between March 2001 and November 2001, as well as the period between December 2007 and June 2009.

Finally we examine whether the return on the S\&P 500 Index affects the dividend payment policies of firms in the following quarter. 
Each dividend announcement is classified according to whether it occurred during an economic recession or expansion according to the NBER, as well as the dividend paying status of the particular firm.

Table 1 displays descriptive statistics for variables that previous literature associates with dividend payment. We also include the quarterly return on the S\&P 500 Index. Mean, Median, Minimum, and Maximum statistics are provided.

Total Assets, which we use as a measure of firm size, is considerably higher at $\$ 11,474$ million for firms that regularly pay dividends, as compared to "switcher" firms with average Total Assets of $\$ 5,654$ million and non-dividend paying firms with average Total Assets of $\$ 1,343$ million. We use Total Assets as our measure of size, rather than market capitalization, because market capitalization is equal to the price of the stock multiplied by the number of shares outstanding. We are attempting to single out the relation between economic conditions and the probability that a firm will pay a dividend. Using market capitalization may cause confounding results because it is influenced by price, which will be relatively high during market expansions and relatively low during recessions.

Our first measure of growth opportunity is measured as "the ratio of the market value of total capital (book value of total assets - book value of equity + market value of equity) to the book value of total assets $\left(\mathrm{V}_{\mathrm{t}} / \mathrm{A}_{\mathrm{t}}\right)$ " (Denis and Obosov, 2008, $\mathrm{p}$ 64). We will henceforth refer to this measure as "Growth Opportunities 1." This measure of growth opportunity implies that non-dividend payers, on average, have higher growth opportunities than both dividend payers and switchers. This supports the cash flow 


\section{Table 1}

\section{Descriptive Statistics for Non-Dividend Paying, Dividend Paying, and Switcher Firms, 1993Q1 - 2009Q2}

The S\&P 500 Qtr. Return is the Quarterly return on the S\&P 500 Index. The Total Assets are reported in millions of US dollars and are equal to the book value of total assets. Growth Opportunities 1 is calculated as the ratio of the market value of total capital to the book value of total assets ((book value of total assetsbook value of equity + market value of equity)/book value of total assets). Growth Opportunities 2 is calculated as the percent change in assets over the quarter. Earned Equity is calculated as ratio of retained earnings to the book value of equity. Profitability 1 is calculated as the ratio of earnings before interest to the book value of total assets. Profitability 2 is calculated as the ratio of after-tax earnings to the book value of equity. Firms are identified as non-dividend payers if they have not paid a regular cash dividend (distribution code "1232" in the CRSP database) within the last 12 quarters. Firms are identified as dividend payers if they paid a regular cash dividend in the previous 12 quarters. If a firm has paid dividends irregularly within the most recent 12 quarters, it is identified as a "Switcher" firm.

\begin{tabular}{|c|c|c|c|c|}
\hline \multirow[b]{2}{*}{ Variable } & Mean & Median & Minimum & Maximum \\
\hline & \multicolumn{4}{|c|}{ Nonpayer } \\
\hline S\&P 500 Qtr. Return & 0.02 & 0.02 & -0.23 & 0.21 \\
\hline Total Assets & $1,343.18$ & 84.47 & 0 & $2,363,878$ \\
\hline Growth Opportunities 1 & 2.70 & 0.98 & 0 & 12,900 \\
\hline Growth Opportunities 2 & $-20,346.42$ & -0.01 & $-872,408,000$ & 20.23 \\
\hline Earned Equity & -9.69 & -0.04 & $-193,778.43$ & 776.98 \\
\hline Profitability 1 & -0.05 & 0 & $-2,132$ & 486 \\
\hline \multirow[t]{2}{*}{ Profitability 2} & -0.28 & 0.01 & $-8,652.75$ & 2,202 \\
\hline & \multicolumn{4}{|c|}{ Payer } \\
\hline S\&P 500 Qtr. Return & 0.02 & 0.02 & -0.23 & 0.21 \\
\hline Total Assets & $11,474.34$ & $1,359.01$ & 0.01 & $2,358,266$ \\
\hline Growth Opportunities 1 & 0.97 & 0.56 & 0 & 454.87 \\
\hline Growth Opportunities 2 & -70.85 & 0 & $-2,366,619$ & 0.36 \\
\hline Earned Equity & 0.30 & 0.65 & $-5,459$ & $7,665.12$ \\
\hline Profitability 1 & 0.01 & 0.01 & -8.33 & 33.84 \\
\hline \multirow[t]{2}{*}{ Profitability 2} & 0.09 & 0.03 & $-1,531.50$ & $1,023.67$ \\
\hline & \multicolumn{4}{|c|}{ Switcher } \\
\hline S\&P 500 Qtr. Return & 0.02 & 0.02 & -0.23 & 0.21 \\
\hline Total Assets & $5,654.43$ & 658.58 & 0.02 & $1,888,599$ \\
\hline Growth Opportunities 1 & 0.84 & 0.44 & 0.00 & 323.50 \\
\hline Growth Opportunities 2 & -27.83 & 0 & $-1,009,032$ & 0.21 \\
\hline Earned Equity & -0.38 & 0.49 & $-12,331$ & 116.88 \\
\hline Profitability 1 & 0.01 & 0 & -8.44 & 10.05 \\
\hline Profitability 2 & 0.15 & 0.03 & -260.00 & 5,395 \\
\hline
\end{tabular}


hypothesis and suggests that mature firms pay dividends because reinvestment opportunities may not provide enough creation of wealth. Shareholders of these firms value distribution of earnings rather than reinvestment in mediocre activities. Nondividend payers, on the other hand, have reinvestment and growth opportunities that maximize shareholder wealth.

The second measure of growth opportunity is measured as the percentage change in assets over the quarter $\left(\mathrm{dA}_{t} / \mathrm{A}_{t}\right)$. We will henceforth refer to this measure of growth opportunities as "Growth Opportunities 2."

Earned Equity is measured as the ratio of retained earnings to book value of equity. In line with intuition, earned equity in the prior quarter tends to be higher for firms that have consistently distributed dividends over the previous twelve quarters. This supports the notion that firms with large cash reserves tend to be dividend payers. Nondividend payers have negative earned equity on average. This implies that on average their retained earnings are negative. Their equity may arise from raising capital through stock issues. This is common for young firms.

We also employ the two measures of profitability noted in Denis and Obosov (2008). The first measure of profitability is measured as the ratio of earnings before interest to the book value of total assets. We will refer to this measure of profitability as "Profitability 1." Profitability1 is higher for dividend payers and switchers, on average. Non-dividend payers have negative profitability, again indicating that average earnings are negative for non-dividend payers and implying that these firms may be young firms.

The second measure of profitability is measured as the ratio of after-tax earnings to the book value of equity. We will refer to this measure of profitability as "Profitability 
2." Switcher firms have the highest value for Profitability2, with dividend payers close behind. Non-dividend payers have negative profitability using this measure, which verifies the results using Profitability1. Switcher firms and dividend paying firms have very similar means and medians of profitability. Despite the similarity in means and medians, switcher firms have a much wider distribution in profitability regardless of the measure used. This wide distribution may explain why switcher firms are not regular dividend payers.

Table 2 introduces the importance of market conditions. It displays summary statistics for determinants of dividend payment according the firms' dividend paying status, as well as the economic cycle, as determined by the NBER. It is a well-accepted fact that financial markets tend to increase in value over the long run; so naturally, there are more observations during expansion periods, as opposed to recession periods.

Confirming intuition, the S\&P 500 has a negative average quarterly return for all types of firms during recession periods, but a positive average quarterly return for all types of firms during expansionary periods. Total assets are also higher, on average, for all firms during expansionary periods and lower during recession periods.

Growth opportunities seem to be higher for non-dividend payers and dividend payers during recessions, while lower for switchers in recessions. This may be due to the fact that some firms classified as switchers may be firms that discontinued dividend payments during the twelve quarter classification period. On average, Growth Opportunities 2 seems inappropriate as all means are negative and variability is extremely large. 
During expansionary periods, the average quarterly earned equity of the prior period for dividend payers is positive, but it highly negative for non-dividend payers, and slightly negative for switchers. Prior to periods labeled as recessionary, average quarterly earned equity is positive and higher for dividend payers, positive for switchers, but negative for non-dividend payers.

On average, Profitability is highest for firms classified as dividend payers, and is slightly higher in recession periods. On the other hand, average Profitability is lowest, and negative, for firms classified as non-dividend payers, and is slightly more negative in recession periods. Average profitability is slightly lower, but still remains positive for switcher firms.

Profitability 2 has similar implications as the first profitability measure in regards to dividend payers and non-dividend payers. Implications for switcher firms differ slightly. Switcher firms have slightly higher average profitability during recessions, when using the second profitability measure.

\subsection{Methodology}

The logistic model is a nonparametric procedure, so it is not restricted to many of the assumptions of parametric procedures. The data does not have to be "normally distributed, linearly related or of equal variance within each group" (Sheskin, 2007). The logistic regression assumes that observations in an analysis are independent of one another. Logistic regressions also require a large sample, according to Wright (1995), because small samples can lead to inaccurate coefficients that have high standard errors.

The logistic model is also appropriate here because a binary logistic model can be 
Table 2

\section{Univariate Statistics According to Dividend Paying Status and Economic Cycle}

The S\&P 500 Qtr. Return is the Quarterly return on the S\&P 500 Index. The Total Assets are reported in millions of US dollars and are equal to the book value of total assets. Growth Opportunities 1 is calculated as the ratio of the market value of total capital to the book value of total assets ((book value of total assets-book value of equity + market value of equity)/book value of total assets). Growth Opportunities 2 is calculated as the percent change in assets over the quarter. Earned Equity is calculated as ratio of retained earnings to the book value of equity. Profitability 1 is calculated as the ratio of earnings before interest to the book value of total assets. Profitability 2 is calculated as the ratio of after-tax earnings to the book value of equity. Firms are identified as non-dividend payers if they have not paid a regular cash dividend (distribution code "1232" in the CRSP database) within the last 12 quarters. Firms are identified as dividend payers if they paid a regular cash dividend in the previous 12 quarters. If a firm has paid dividends irregularly within the most recent 12 quarters, it is identified as a "Switcher" firm. A quarter is labeled as expansion or recession if it is classified as such by the National Bureau of Economic Research. According to the NBER recessions occurred between March 2001 and November 2001 and between December 2007 and June 2009.

\begin{tabular}{|c|c|c|c|c|c|c|c|c|}
\hline \multirow[b]{3}{*}{ Variable } & \multicolumn{4}{|c|}{ Expansion } & \multicolumn{4}{|c|}{ Recession } \\
\hline & \multicolumn{4}{|c|}{ Nonpayer } & \multicolumn{4}{|c|}{ Nonpayer } \\
\hline & Mean & Median & Minimum & Maximum & Mean & Median & Minimum & Maximum \\
\hline S\&P 500 Qtr. Return & 0.031 & 0.029 & -0.176 & 0.209 & -0.068 & -0.099 & -0.226 & 0.152 \\
\hline Total Assets & 1,288 & 80 & 0 & $2,363,878$ & 1,728 & 127 & 0 & $1,097,188$ \\
\hline Growth Opportunities 1 & 2.65 & 1.00 & 0.00 & $12,900.00$ & 3.00 & 0.84 & 0.00 & $9,467.15$ \\
\hline Growth Opportunities 2 & $-21,196.1$ & -0.006 & $-8.72 \mathrm{E}+08$ & 20.226 & $-14,446.4$ & -0.003 & $-252,708,531$ & 4.579 \\
\hline Earned Equity & -9.298 & -0.028 & $-92,317$ & 776.982 & -12.365 & -0.109 & $-193,778.426$ & 99.821 \\
\hline Profitability 1 & -0.049 & 0.003 & -2132 & 486 & -0.055 & 0.000 & -99.429 & 13 \\
\hline \multirow[t]{2}{*}{ Profitability 2} & -0.285 & 0.010 & $-8,652.750$ & 2202 & -0.207 & 0.002 & -540 & $1,499.741$ \\
\hline & \multicolumn{4}{|c|}{ Payer } & \multicolumn{4}{|c|}{ Payer } \\
\hline S\&P 500 Qtr. Return & 0.036 & 0.031 & -0.176 & 0.209 & -0.067 & -0.089 & -0.226 & 0.152 \\
\hline Total Assets & 10,483 & 1,279 & 0 & $2,254,394$ & 17,436 & 2,017 & 1 & $2,358,266$ \\
\hline Growth Opportunities 1 & 0.96 & 0.57 & 0.00 & 454.87 & 1.05 & 0.48 & 0.00 & 367.24 \\
\hline Growth Opportunities 2 & -82.217 & 0.000 & $-2,366,619$ & 0.359 & -2.501 & 0.000 & $-3,453.633$ & 0.033 \\
\hline Earned Equity & 0.116 & 0.645 & $-5,459$ & $1,518.667$ & 1.417 & 0.649 & -63.622 & $7,665.115$ \\
\hline Profitability 1 & 0.013 & 0.008 & -8.326 & 33.842 & 0.015 & 0.005 & -1.054 & 12.488 \\
\hline Profitability 2 & 0.094 & 0.031 & $-1,531.500$ & 1023.667 & 0.084 & 0.025 & -388.731 & 279.160 \\
\hline
\end{tabular}


Table 2 (continued)

Univariate Statistics According to Dividend Paying Status and Economic Cycle

\begin{tabular}{|c|c|c|c|c|c|c|c|c|}
\hline \multirow[b]{3}{*}{ Variable } & \multicolumn{4}{|c|}{ Expansion } & \multicolumn{4}{|c|}{ Recession } \\
\hline & \multicolumn{4}{|c|}{ Switcher } & \multicolumn{4}{|c|}{ Switcher } \\
\hline & Mean & Median & Minimum & Maximum & Mean & Median & Minimum & Maximum \\
\hline S\&P 500 Qtr. Return & 0.034 & 0.025 & -0.137 & 0.209 & -0.066 & -0.099 & -0.226 & 0.152 \\
\hline Total Assets & 5,388 & 621 & 0 & $1,888,599$ & 7,467 & 949 & 1 & 953,427 \\
\hline Growth Opportunities 1 & 0.85 & 0.45 & 0.00 & 323.50 & 0.73 & 0.37 & 0.00 & 49.76 \\
\hline Growth Opportunities 2 & -31.785 & 0.000 & $-1,009,032$ & 0.209 & -0.910 & 0.000 & $-1,942.323$ & 0.140 \\
\hline Profitability 1 & 0.009 & 0.005 & -8.443 & 10.048 & 0.006 & 0.003 & -1.046 & 1.131 \\
\hline Profitability 2 & 0.032 & 0.027 & -260 & 254.3862 & 0.930 & 0.022 & -19.767 & 5,395 \\
\hline
\end{tabular}


employed so that the dependent variable is comprised of two categories. It allows for computation of a probability that will always fall between 0 and 1 .

\subsection{Empirical Results}

The purpose of this essay is to determine the probability that a firm will or will not make a dividend payment. We expect that factors noted as significant in other related studies, such as the firms profitability, earnings, and size, will be significant in determining whether a firm will pay dividends or not.

Previous research, surveys in particular, point out that managers are reluctant to change dividend payment policies. These surveys note a general feeling of obligation to continue dividend payments for firms that have historically paid dividends. As such, we believe a firm's recent dividend paying history largely determines whether a firm will or will not pay a dividend in the coming quarter.

The recent recession and financial troubles of firms worldwide also highlights another factor that may be important in determining the probability that a firm will announce a dividend payment or not: market conditions.

As noted above, dividend paying history and market conditions have never before been studied as possible determinants for cash distribution policies.

Because the focus of this essay is on the likelihood of a specific outcome, a dividend distribution, or lack thereof, we find it appropriate to employ a binary logistic regression. In particular, we model the probability that a firm will not pay a dividend. If a firm does not pay a dividend, the dependent variable will be equal to 1 . If a firm pays a dividend, the dependent variable will be equal to 0 .

The null hypothesis and alternative hypothesis are stated below: 
H0: Dividend non-payment cannot be predicted by firm profitability, earnings, size, dividend payment history, or market conditions.

HA: Dividend non-payment can be predicted by firm profitability, earnings, size, and dividend payment history, as well as market conditions.

Table 3 tabulates the number for cases where a firm did or did not pay a dividend according to the firms' dividend paying status and the economic climate during the dividend announcement. This table highlights the importance of dividend paying history in determining whether a firm will or will not pay a dividend. Financial markets tend to expand over the long run, so naturally there are more quarters labeled as expansionary by the NBER. According to the NBER, between 1993 and 2009, recessions occurred from March 2001 through November 2001 and December 2007 through June 2009. Therefore, our sample has ten quarters labeled as recession quarters. During recessions, most nondividend paying firms continue to not pay dividends. In only $0.4 \%$ of cases between 1993 and 2009, did non-dividend paying firms begin to pay dividends. In the other extreme, dividend payers continued to pay dividends through recessions in $96.88 \%$ of instances, with dividends being omitted or suspended only $3.12 \%$ of the time. Switchers distributed dividends in $74.31 \%$ of cases, but did not distribute dividends $25.69 \%$ of the time.

In expansionary periods, non-dividend paying firms are a little more likely ( $1.53 \%$ of cases) to initiate dividend payments. For the most part, however, they continue as non-dividend payers. A high number of dividend payers continue to pay dividends ( $96.37 \%$ of cases), but in $3.63 \%$ instances, a dividend payer omitted or suspended dividend payments. Switchers see the most difference between expansions and recessions. This may be because their earnings and profitability have higher volatility as 
Table 3

Number of Instances when Firms Paid or Did Not Pay a Dividend According to Dividend Paying Status and Economic Cycle

Firms are identified as non-dividend payers if they have not paid a regular cash dividend (distribution code "1232" in the CRSP database) within the last 12 quarters. Firms are identified as dividend payers if they paid a regular cash dividend in the previous 12 quarters. If a firm has paid dividends irregularly within the most recent 12 quarters, it is identified as a "Switcher" firm. Once classified by its previous 12 quarters, it is determined if a firm paid a dividend or not in the next quarter. If the firm paid a dividend in the next quarter, that instance is counted in the "Paid" column, whereas if a firm did not pay a dividend in the next quarter, that instance is counted in the "Did not Pay" column. A quarter is labeled as expansion or recession if it is classified as such by the National Bureau of Economic Research. According to the NBER recessions occurred between March 2001 and November 2001 and between December 2007 and June 2009.

\begin{tabular}{|c|c|c|c|c|c|c|c|c|c|c|c|c|}
\hline \multirow[b]{3}{*}{ Nonpayer } & \multicolumn{6}{|c|}{ Recession } & \multicolumn{6}{|c|}{ Expansion } \\
\hline & \multicolumn{2}{|c|}{ Paid } & \multicolumn{2}{|c|}{ Did not Pay } & \multicolumn{2}{|c|}{ Total } & \multicolumn{2}{|c|}{ Paid } & \multicolumn{2}{|c|}{ Did Not Pay } & \multicolumn{2}{|c|}{ Total } \\
\hline & 154 & $0.40 \%$ & 38,475 & $99.60 \%$ & 38,629 & $100 \%$ & 4,103 & $1.53 \%$ & 264,065 & $98.47 \%$ & 268,168 & $100 \%$ \\
\hline Payer & 10,099 & $96.88 \%$ & 325 & $3.12 \%$ & 10,424 & $100 \%$ & 60,410 & $96.37 \%$ & 2,275 & $3.63 \%$ & 62,685 & $100 \%$ \\
\hline Switcher & 5,121 & $74.31 \%$ & 1,770 & $25.69 \%$ & 6,891 & $100 \%$ & 37,073 & $79.12 \%$ & 9,785 & $20.88 \%$ & 46,858 & $100 \%$ \\
\hline
\end{tabular}


seen in Tables 1 and 2 . In expansionary periods, switcher firms paid dividends $79.12 \%$ of the time, while skipping dividends in $20.88 \%$ of cases.

In order to determine whether the factors such as earnings, profitability, growth opportunities, dividend paying history, and market conditions can predict dividend nonpayment in a particular quarter, we use forward selection. Forward selection allows for variables to be added to the model one by one to determine if the factor is significant and contributes to the model. This is useful as we have two measures of profitability and growth opportunity, and three different measures of economic conditions.

The first model we test is

$$
\begin{aligned}
\operatorname{Pr}\left(\text { Payment }_{t}\right)= & \alpha+\beta_{1} \text { Nonpayer }+\beta_{2} \text { Payer }+\beta_{3} \text { Expansion }+\beta_{4} \text { Nonpayer } * \\
& \text { Expansion }_{t-1}+\beta_{5} \text { Payer } * \text { Expansion }_{t-1}+\beta_{6} \text { Total Asset }_{t-1}+ \\
& \beta_{7}{\text { GrowthOpportunity } 1_{t-1}+\beta_{8} \text { Profitability }_{t-1}}_{t}
\end{aligned}
$$

The Status effect is represented by the two binary variables: Nonpayer and Payer. The binary variable "Nonpayer" is equal to 1 if the firm has not paid a regular cash dividend (distribution code " 1232 " in the CRSP database) within the previous 12 quarters, and it is equal to 0 otherwise. The binary variable "Payer" is equal to 1 if the firm has paid a regular cash dividend (distribution code "1232" in the CRSP database) in all of the previous 12 quarters, and it is equal to 0 otherwise. We measure the effect of the market according to the expansions and contractions defined by the NBER. The Economic Cycle effect is introduced as a binary variable called Expansion that is equal to 1 if the market is in an expansionary quarter and 0 when the market is in a contraction or recession period. Total Assets is the book value of total assets in the prior quarter. Growth Opportunities 1 is calculated as the ratio of the market value of total capital to the 
book value of total assets ((book value of total assets-book value of equity + market value of equity)/book value of total assets) in the prior quarter. Profitability 1 is calculated as the ratio of earnings before interest to the book value of total assets in the prior quarter.

Each variable is added to the model one by one. Panels 1 through 4 of Table 4 display the results of the forward selection process. According to Panel 1, remarkable improvements are made in the prediction of non-payment by including the variables in Equation 1. The Likelihood Ratio, the Schwarz Criterion, and the Akaike Information Criterion improve from 489,666; 486,669; and 486,679, respectively, when only the intercept is included to 116,$893 ; 116,911$; and 116,911 , respectively, when the variables in equation 1 are included.

Panel 2 displays a type 3 analysis of effects based on the Wald test. All of the variables in equation 1 are statistically significant at the $5 \%$ level, indicating that these factors affect dividend non-payment in the coming quarter. In fact, all effects, except Growth Opportunity, are significant at the $0.01 \%$ level. Another interesting result, is the statistical significance of the Status*EconomicCycle interaction effect. This indicates evidence that economic cycles affect dividend paying, non-dividend paying, and switcher firms differently.

Panel 3 displays the parameter estimates for Equation 1. The ExpEst column contains the exponentiated parameter estimates, which represent the odds ratios for the variables. If the figure in Estimate column is positive, the odds ratio indicates "the amount of increase in the Log odds for a one-unit increase in the predictor variable" (Sheskin, 2007, p 1596). If the Estimate is negative, then the odds ratio is the amount of 
Table 4

\section{Forward Selection Procedure With Growth Opportunities 1 and Profitability 1 and NBER Market Measure}

The probability modeled is that Payment $=$ 'No'. There were 309,742 instances between the first quarter of 1993 and the second quarter of 2010 in which firms did not pay a dividend. There were 111,420 instances between the first quarter of 1993 and the second quarter of 2010 in which firms paid a dividend. Using a binary logit model and Fisher's scoring optimizing technique, variables are selected using forward selection process. The Status effect is represented by the two binary variables: Nonpayer and Payer. The binary variable "Nonpayer" is equal to 1 if the firm has not paid a regular cash dividend (distribution code " 1232 " in the CRSP database) within the previous 12 quarters, and it is equal to 0 otherwise. The binary variable "Payer" is equal to 1 if the firm has paid a regular cash dividend (distribution code "1232" in the CRSP database) in all of the previous 12 quarters, and it is equal to 0 otherwise. We measure the effect of the market according to the expansion and contractions defined by the NBER. The Economic Cycle effect is introduced as a binary variable called Expansion that is equal to 1 if the market is in an expansionary quarter and 0 when the market is in a contraction or recession period. Total Assets is the book value of total assets in the prior quarter. Growth Opportunities 1 is calculated as the ratio of the market value of total capital to the book value of total assets ((book value of total assets-book value of equity + market value of equity)/book value of total assets) in the prior quarter. Profitability 1 is calculated as the ratio of earnings before interest to the book value of total assets in the prior quarter.

\begin{tabular}{cccc}
\hline \multicolumn{5}{c}{ Panel 1: Fit Statistics } \\
\hline Step & -2 Log L & AIC & SC \\
\hline 0 & $486,666.46$ & 486,668 & 486,679 \\
1 & $117,619.38$ & $117,625.38$ & $117,658.23$ \\
2 & $117,373.39$ & $117,381.39$ & $117,425.20$ \\
3 & $117,088.93$ & $117,100.93$ & $117,166.64$ \\
4 & $117,047.78$ & $117,061.78$ & $117,138.44$ \\
5 & $116,934.43$ & $116,950.43$ & $117,038.03$ \\
6 & $116,893.22$ & $116,911.22$ & $117,009.77$ \\
\hline \multicolumn{5}{c}{ Panel 2:Type 3 Analysis of Effects with Effect Coding } \\
\hline \multicolumn{5}{c}{} \\
\hline \multicolumn{5}{c}{ Effect } & DF & Wald ChiSq & Prob \\
\hline Status & 2 & 24462.5396 & $<.0001$ \\
Economic Cycle & 1 & 213.8736 & $<.0001$ \\
Status*Economic Cycle & 2 & 215.2143 & $<.0001$ \\
Total Assets & 1 & 36.7924 & $<.0001$ \\
Growth Opportunities 1 & 1 & 126.6917 & $<.0001$ \\
Profitability 1 & 1 & 116.8697 & $<.0001$ \\
\hline
\end{tabular}


Table 4 (continued)

Forward Selection Procedure With Growth Opportunities 1 and Profitability 1 and NBER Market Measure

\begin{tabular}{|c|c|c|c|c|c|c|c|c|}
\hline \multicolumn{9}{|c|}{ Panel 3: Type 3 Parameter Estimates with Effect Coding } \\
\hline Variable & ClassVal0 & ClassVal1 & DF & Estimate & StdErr & Wald ChiSq & $\begin{array}{c}\text { Prob } \\
\text { ChiSq }\end{array}$ & ExpEst \\
\hline Intercept & & & 1 & $0.0795^{* * *}$ & 0.0188 & 17.88 & $<.0001$ & 1.083 \\
\hline Status & Nonpayer & & 1 & $4.7417^{* * *}$ & 0.0309 & $23,577.36$ & $<.0001$ & 114.626 \\
\hline Status & Payer & & 1 & $-3.4546^{* * *}$ & 0.0255 & $18,328.36$ & $<.0001$ & 0.032 \\
\hline Economic Cycle & Expansion & & 1 & $-0.268^{* * *}$ & 0.0183 & 213.87 & $<.0001$ & 0.765 \\
\hline Status*Economic Cycle & Nonpayer & Expansion & 1 & $-0.4401^{* * *}$ & 0.0308 & 203.79 & $<.0001$ & 0.644 \\
\hline Status*Economic Cycle & Payer & Expansion & 1 & $0.3313^{* * *}$ & 0.0255 & 168.80 & $<.0001$ & 1.393 \\
\hline Total Assets & & & 1 & $-1.46 \mathrm{E}-06^{* * *}$ & $2.42 \mathrm{E}-07$ & 36.79 & $<.0001$ & 1 \\
\hline Growth Opportunities 1 & & & 1 & $0.039^{* * *}$ & 0.00347 & 126.69 & $<.0001$ & 1.04 \\
\hline Profitability 1 & & & 1 & $-0.0894^{* * *}$ & 0.00827 & 116.87 & $<.0001$ & 0.914 \\
\hline
\end{tabular}

\begin{tabular}{lrrr}
\hline \multicolumn{4}{c}{ Panel 4: Type 3 Odds Ratio Estimates } \\
\hline \multicolumn{1}{c}{ Effect } & OddsRatioEst & LowerCL & UpperCL \\
\hline Total Assets & 1 & 1 & 1 \\
Growth Opportunities 1 & 1.04 & 1.033 & 1.047 \\
Profitability1 & 0.914 & 0.9 & 0.929 \\
\hline
\end{tabular}


decrease in the Log odds attributable to a one-unit increase in the predictor variable. The odds ratios are also displayed in Panel 4 for non-categorical variables.

These results indicate that a firm classified as a non-payer, based on its lack of dividend distributions over the previous twelve quarters, is $114.63 \%$ more likely to not pay a dividend in the coming quarter during a recession. On the other hand, if the market is in an expansionary period, a non-dividend paying firm is $0.64 \%$ less likely to continue its non-dividend paying course. A dividend paying firm is $0.032 \%$ less likely to not pay a dividend over a switcher firm during a recession. This is relatively intuitive, since previous literature has noted managers' reluctance to change distribution policies, and discontinuation of dividend payments during a recession can be extremely damaging to a firm.

Seemingly counterintuitive, a dividend paying firm is $1.393 \%$ more likely to omit a dividend payment during an expansion, as opposed to a recession. This may be explainable if we take previous literature into account. If managers forecast that earnings cannot keep up with cash distributions, they may use an economic expansionary period (when bad news may be less damaging) to announce dividend suspensions. This new and counterintuitive finding has not previously been noted in other studies

During an expansion, a switcher firm is $0.765 \%$ less likely to omit a dividend. This is also intuitive. It is likely that many of these switcher firms began paying dividends in the recent past, or have a pattern of sporadic dividend payments. Table 1 also noted greater variability in profitability for switcher firms. Therefore, they are more likely to pay dividends, and less likely to omit or discontinue dividends, during an economic expansion. 
If a firm experiences a one unit increase in total assets, it is $1 \%$ less likely to not pay a dividend compared to a firm whose asset size did not change. Profitability also shows similar evidence. A one unit increase in profitability implies that a firm is $0.014 \%$ less likely to not pay a dividend. These results support previous literature, where large size and profitability have been linked with dividend payment. On the other hand, a one unit increase in growth opportunities increases the likelihood that a firm will not pay a dividend in the coming quarter by $1.04 \%$. This is also intuitive and supports previous literature. Firms with more growth opportunities are more likely to retain earnings for reinvestment, rather than distribute them in the form of dividends.

The second model we test is

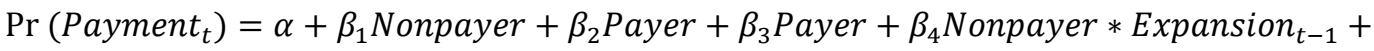

$$
\begin{aligned}
& \beta_{5} \text { Payer }_{* \text { Expansion }_{t-1}}+\beta_{6} \text { Total Assets }_{t-1}+ \\
& \beta_{7} \text { GrowthOpportunity } 1_{t-1}+\beta_{8} \text { Profitability } 1_{t-1}
\end{aligned}
$$

The Status effect is represented by the two binary variables: Nonpayer and Payer. The binary variable "Nonpayer" is equal to 1 if the firm has not paid a regular cash dividend (distribution code "1232" in the CRSP database) within the previous 12 quarters, and it is equal to 0 otherwise. The binary variable "Payer" is equal to 1 if the firm has paid a regular cash dividend (distribution code "1232" in the CRSP database) in all of the previous 12 quarters, and it is equal to 0 otherwise. We measure the effect of the market according to the standard definition of a recession. The Economic Cycle effect is introduced as a binary variable called Expansion that is equal to 1 if GDP has not declined for two or more consecutive quarters, and 0 otherwise. Total Assets is the book value of total assets in the prior quarter. Growth Opportunities 1 is calculated as the ratio 
of the market value of total capital to the book value of total assets ((book value of total assets-book value of equity + market value of equity)/book value of total assets) in the prior quarter. Profitability 1 is calculated as the ratio of earnings before interest to the book value of total assets in the prior quarter.

Each variable is added to the model one by one. Panels 1 through 5 of Table 5 display the results of the forward selection process. The Likelihood Ratio, the Schwarz Criterion, and the Akaike Information Criterion improve from 486,667; 486,668; and 486,679 , respectively, when only the intercept is included to 117,$580 ; 117,588$; and 117,632 , respectively, once the forward selection process is complete.

Panel 2 displays Type 3 analysis of effects based on the Wald test. Of the five variables in Model 2, only dividend paying Status and Size, proxied by Total Assets, significantly contribute to a firm's lack of payment in the coming quarter. In this model, dividend paying history is an important determinant of dividend payment, but the state of the economy is not. This may be due to the fact that this model defines an economic recession as two or more consecutive declines in Gross Domestic Product (GDP). This definition does not include other pertinent information such as unemployment or consumer confidence, which also contribute to overall market conditions.

Panel 4 displays odds ratios for the statistically significant variables in Model 2. According to this model, a non-dividend payer is $265 \%$ more likely to omit a dividend than a switcher firm. A dividend payer is $0.136 \%$ less likely, than a switcher firm, to omit a dividend. As in Model 1, a one unit increase in Total Assets is associated with a 1\% decrease in the likelihood that the firm will not pay a dividend in the coming quarter. 


\section{Table 5}

\section{Forward Selection Procedure With Growth Opportunities 1 and Profitability 1 and GDP Market Measure}

The probability modeled is that Payment $=$ 'No'. There were 309,742 instances between the first quarter of 1993 and the second quarter of 2010 in which firms did not pay a dividend. There were 111,420 instances between the first quarter of 1993 and the second quarter of 2010 in which firms paid a dividend. Using a binary logit model and Fisher's scoring optimizing technique, variables are selected using forward selection process. The Status effect is represented by the two binary variables: Nonpayer and Payer. The binary variable "Nonpayer" is equal to 1 if the firm has not paid a regular cash dividend (distribution code "1232" in the CRSP database) within the previous 12 quarters, and it is equal to 0 otherwise. The binary variable "Payer" is equal to 1 if the firm has paid a regular cash dividend (distribution code " 1232 " in the CRSP database) in all of the previous 12 quarters, and it is equal to 0 otherwise. We measure the effect of the market according to the standard definition of a recession. The Economic Cycle effect is introduced as a binary variable called Expansion that is equal to 1 if GDP declines for two or more consecutive quarters and 0 otherwise. Total Assets is the book value of total assets in the prior quarter. Growth Opportunities 1 is calculated as the ratio of the market value of total capital to the book value of total assets ((book value of total assets-book value of equity + market value of equity)/book value of total assets) in the prior quarter. Profitability 1 is calculated as the ratio of earnings before interest to the book value of total assets in the prior quarter.

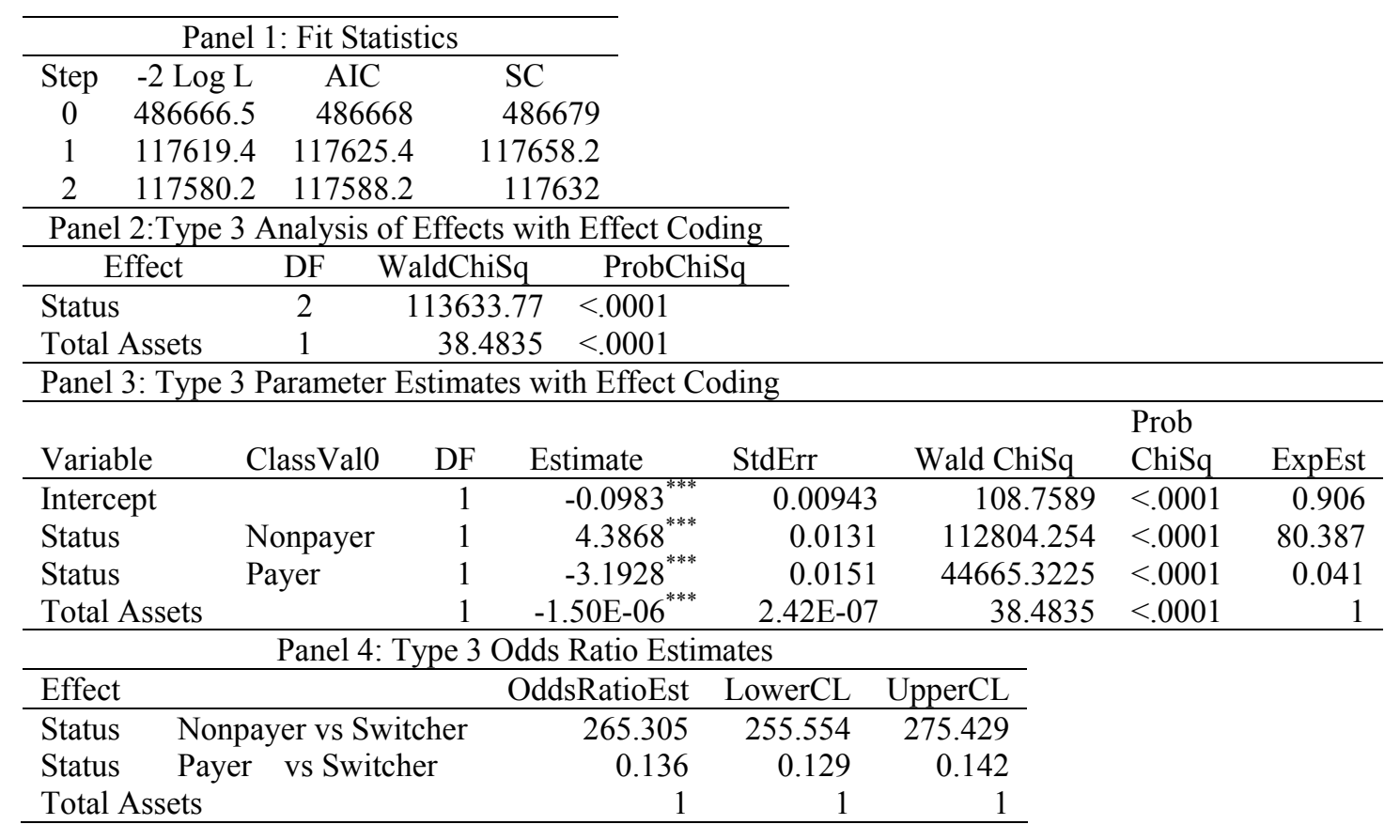


Table 6

\section{Forward Selection Procedure With Growth Opportunities 1 and Profitability 1 and S\&P 500 Market Measure}

The probability modeled is that Payment $=$ 'No'. There were 309,742 instances between the first quarter of 1993 and the second quarter of 2010 in which firms did not pay a dividend. There were 111,420 instances between the first quarter of 1993 and the second quarter of 2010 in which firms paid a dividend. Using a binary logit model and Fisher's scoring optimizing technique, variables are selected using forward selection process. The Status effect is represented by the two binary variables: Nonpayer and Payer. The binary variable "Nonpayer" is equal to 1 if the firm has not paid a regular cash dividend (distribution code " 1232 " in the CRSP database) within the previous 12 quarters, and it is equal to 0 otherwise. The binary variable "Payer" is equal to 1 if the firm has paid a regular cash dividend (distribution code "1232" in the CRSP database) in all of the previous 12 quarters, and it is equal to 0 otherwise. We measure economic conditions as the return on the S\&P 500 from the previous quarter. Total Assets is the book value of total assets in the prior quarter. Growth Opportunities 1 is calculated as the ratio of the market value of total capital to the book value of total assets ((book value of total assets-book value of equity + market value of equity)/book value of total assets) in the prior quarter. Profitability 1 is calculated as the ratio of earnings before interest to the book value of total assets in the prior quarter.

\begin{tabular}{|c|c|c|c|c|c|c|c|c|}
\hline \multicolumn{4}{|c|}{ Panel 1: Fit Statistics } & & & & & \\
\hline Step & $-2 \log \mathrm{L}$ & $\mathrm{AIC}$ & $\mathrm{SC}$ & & & & & \\
\hline 0 & 486666.5 & 486668 & 486679 & & & & & \\
\hline 1 & 117619.4 & 117625.4 & 117658.2 & & & & & \\
\hline 2 & 117489.4 & 117497.4 & 117541.2 & & & & & \\
\hline 3 & 117452.1 & 117462.1 & 117516.9 & & & & & \\
\hline \multicolumn{9}{|c|}{ Panel 2:Type 3 Analysis of Effects with Effect Coding } \\
\hline & Effect & DF & Wald ChiSq & \multicolumn{2}{|c|}{ Prob ChiSq } & & & \\
\hline Status & & 11 & $113,232.64$ & \multicolumn{2}{|c|}{$<.0001$} & & & \\
\hline S\&P 5 & 0 Qtr. Return & 1 & 127.89 & \multicolumn{2}{|c|}{$<.0001$} & & & \\
\hline \multicolumn{2}{|c|}{ Total Assets } & 1 & 36.59 & \multicolumn{2}{|c|}{$<.0001$} & & & \\
\hline \multicolumn{9}{|c|}{ Panel 3: Type 3 Parameter Estimates with Effect Coding } \\
\hline & Variable & ClassVal0 & DF & Estimate & StdErr & Wald ChiSq & Prob ChiSq & ExpEst \\
\hline \multicolumn{2}{|c|}{ Intercept } & & 1 & $-0.1222^{* * *}$ & 0.00967 & 159.51 & $<.0001$ & 0.885 \\
\hline \multicolumn{2}{|c|}{ Status } & Nonpayer & 1 & $4.3935^{* * *}$ & 0.0131 & $112,427.48$ & $<.0001$ & 80.921 \\
\hline \multicolumn{2}{|l|}{ Status } & Payer & 1 & $-3.1967^{* * * *}$ & 0.0151 & $44,687.38$ & $<.0001$ & 0.041 \\
\hline \multicolumn{3}{|c|}{ S\&P 500 Qtr. Return } & 1 & $1.1364^{* * *}$ & 0.1005 & 127.89 & $<.0001$ & 3.116 \\
\hline \multicolumn{3}{|c|}{ Total Assets } & 1 & $-1.46 \mathrm{E}-06^{* * *}$ & $2.41 \mathrm{E}-07$ & 36.59 & $<.0001$ & 1 \\
\hline
\end{tabular}


Table 6 (continued)

Forward Selection Procedure With Growth Opportunities 1 and Profitability 1 and S\&P 500 Market Measure

\begin{tabular}{|c|c|c|c|c|}
\hline \multicolumn{5}{|c|}{ Panel 4: Type 3 Odds Ratio Estimates } \\
\hline & Effect & OddsRatioEst & LowerCL & UpperCL \\
\hline Status & Nonpayer vs Switcher & 267.79 & 257.917 & 278.04 \\
\hline Status & Payer vs Switcher & 0.135 & 0.129 & 0.142 \\
\hline \multicolumn{2}{|c|}{ S\&P 500 Qtr. Return } & 3.116 & 2.559 & 3.794 \\
\hline \multicolumn{2}{|c|}{ Total Assets } & 1 & 1 & 1 \\
\hline
\end{tabular}


The third model we test is

$$
\begin{aligned}
& \operatorname{Pr}\left(\text { Payment }_{t}\right)=\alpha+\beta_{1} \text { Nonpayer }+\beta_{2} \text { Payer }+\beta_{3} \text { S\&P500Ret }+\beta_{4} \text { Total Assets }_{t-1}+ \\
& \beta_{5} \text { GrowthOpportunity } 1_{t-1}+\beta_{6} \text { Profitability } 1_{t-1}
\end{aligned}
$$

The Status effect is represented by the two binary variables: Nonpayer and Payer. The binary variable "Nonpayer" is equal to 1 if the firm has not paid a regular cash dividend (distribution code "1232" in the CRSP database) within the previous 12 quarters, and it is equal to 0 otherwise. The binary variable "Payer" is equal to 1 if the firm has paid a regular cash dividend (distribution code "1232" in the CRSP database) in all of the previous 12 quarters, and it is equal to 0 otherwise. We measure economic conditions using the return on the S\&P 500 from the previous quarter. Total Assets is the book value of total assets in the prior quarter. Growth Opportunities 1 is calculated as the ratio of the market value of total capital to the book value of total assets ((book value of total assets-book value of equity + market value of equity)/book value of total assets) in the prior quarter. Profitability 1 is calculated as the ratio of earnings before interest to the book value of total assets in the prior quarter.

Each variable is added to the model one by one. Panels 1 through 4 of Table 6 display the results of the forward selection process. Of the five variables in Model 3, only three of them are determined to be significant using the forward selection process: Status, S\&P 500 Return in the previous quarter and Total Assets. Although this model excludes factors such Profitability and Growth Opportunities, it does imply that the dividend paying history of a firm as well as its size and opportunities for growth are likely to determine whether or not the firm will make a dividend payment in the following quarter. Panel 3 indicates that these factors are statistically significant at the $0.01 \%$ level. 
The fourth model we test is

$$
\begin{aligned}
& \operatorname{Pr}\left(\text { Payment }_{t}\right)=\alpha+\beta_{1} \text { Nonpayer }+\beta_{2} \text { Payer }+\beta_{3} \text { Expansion }+\beta_{4} \text { Nonpayer } * \\
& \text { Expansion }_{t-1}+\beta_{5} \text { Payer } * \text { Expansion }_{t-1}+\beta_{6} \text { Total Asset }_{t-1}+ \\
& \beta_{7} \text { GrowthOpportunity } 2_{t-1}+\beta_{8} \text { Profitability } 2_{t-1}
\end{aligned}
$$

The Status effect is represented by the two binary variables: Nonpayer and Payer. The binary variable "Nonpayer" is equal to 1 if the firm has not paid a regular cash dividend (distribution code "1232" in the CRSP database) within the previous 12 quarters, and it is equal to 0 otherwise. The binary variable "Payer" is equal to 1 if the firm has paid a regular cash dividend (distribution code "1232" in the CRSP database) in all of the previous 12 quarters, and it is equal to 0 otherwise. We measure the effect of the market according to the expansion and contractions defined by the NBER. The Economic Cycle effect is introduced as a binary variable called Expansion that is equal to 1 if the market is in an expansionary quarter and 0 when the market is in a contraction or recession period. The Total Assets are reported in millions of US dollars and are equal to the book value of total assets. Growth Opportunities 2 is calculated as the percent change in assets over the quarter. Earned Equity is calculated as ratio of retained earnings to the book value of equity. Profitability 2 is calculated as the ratio of after-tax earnings to the book value of equity.

Each variable is added to the model one by one. Panels 1 through 5 of Table 7 display the results of the forward selection process. In this model, four of the five variables are selected as significant in the forward selection process. Panel 2 displays the Type 3 analysis of effects based on the Wald test. Status, Economic Cycle, the interaction term Status*Economic Cycle, and Total Assets in the previous period are determined to 
Table 7

Forward Selection Procedure With Growth Opportunities 2 and Profitability 2 and NBER Market Measure

The probability modeled is that Payment $=$ 'No'. There were 309,742 instances between the first quarter of 1993 and the second quarter of 2010 in which firms did not pay a dividend. There were 111,420 instances between the first quarter of 1993 and the second quarter of 2010 in which firms paid a dividend. Using a binary logit model and Fisher's scoring optimizing technique, variables are selected using forward selection process. The Status effect is represented by the two binary variables: Nonpayer and Payer. The binary variable "Nonpayer" is equal to 1 if the firm has not paid a regular cash dividend (distribution code " 1232 " in the CRSP database) within the previous 12 quarters, and it is equal to 0 otherwise. The binary variable "Payer" is equal to 1 if the firm has paid a regular cash dividend (distribution code "1232" in the CRSP database) in all of the previous 12 quarters, and it is equal to 0 otherwise. We measure the effect of the market according to the expansion and contractions defined by the NBER. The Economic Cycle effect is introduced as a binary variable called Expansion that is equal to 1 if the market is in an expansionary quarter and 0 when the market is in a contraction or recession period. The Total Assets are reported in millions of US dollars and are equal to the book value of total assets. Growth Opportunities 2 is calculated as the percent change in assets over the quarter. Earned Equity is calculated as ratio of retained earnings to the book value of equity. Profitability 2 is calculated as the ratio of after-tax earnings to the book value of equity.

\begin{tabular}{|c|c|c|c|c|}
\hline \multicolumn{4}{|c|}{ Panel 1: Fit Statistics } & \\
\hline Step & $-2 \log L$ & AIC & $\mathrm{SC}$ & \\
\hline 0 & 486575.77 & 486578 & 486589 & \\
\hline 1 & 117599.86 & 117605.86 & 117638.71 & \\
\hline 2 & 117354.46 & 117362.46 & 117406.26 & \\
\hline 3 & 117070.09 & 117082.09 & 117147.79 & \\
\hline 4 & 117028.98 & 117042.98 & 117119.64 & \\
\hline \multicolumn{5}{|c|}{ Panel 2:Type 3 Analysis of Effects with Effect Coding } \\
\hline Effect & & DF & Wald ChiSq & Prob ChiSq \\
\hline Status & & 2 & 24735.246 & $<.0001$ \\
\hline Econo & Cycle & 1 & 209.4451 & $<.0001$ \\
\hline Status & onomic Cycle & 2 & 214.1404 & $<.0001$ \\
\hline Total & ets & 1 & 40.6038 & $<.0001$ \\
\hline
\end{tabular}


Table 7 (continued)

Forward Selection Procedure With Growth Opportunities 2 and Profitability 2 and NBER Market Measure

\begin{tabular}{|c|c|c|c|c|c|c|c|c|}
\hline \multicolumn{9}{|c|}{ Panel 3: Type 3 Parameter Estimates with Effect Coding } \\
\hline Variable & ClassVal0 & ClassVal1 & $\mathrm{DF}$ & Estimate & StdErr & WaldChiSq & ProbChiSq & ExpEst \\
\hline Intercept & & & 1 & $0.125^{* * *}$ & 0.0184 & 46.2754 & $<.0001$ & 1.133 \\
\hline Status & Nonpayer & & 1 & $4.7663^{* * *}$ & 0.0308 & 23888.46 & $<.0001$ & 117.481 \\
\hline Status & Payer & & 1 & $-3.4633^{* * *}$ & 0.0255 & 18432.852 & $<.0001$ & 0.031 \\
\hline Economic Cycle & Expansion & & 1 & $-0.2652^{* * *}$ & 0.0183 & 209.4451 & $<.0001$ & 0.767 \\
\hline Status*Economic Cycle & Nonpayer & Expansion & 1 & $-0.439^{* * *}$ & 0.0308 & 202.7307 & $<.0001$ & 0.645 \\
\hline Status*Economic Cycle & Payer & Expansion & 1 & $0.3305^{* * *}$ & 0.0255 & 168.0346 & $<.0001$ & 1.392 \\
\hline Total Assets & & & 1 & $-1.54 \mathrm{E}-06^{* * *}$ & $2.42 \mathrm{E}-07$ & 40.6038 & $<.0001$ & 1 \\
\hline
\end{tabular}

Panel 4: Type 3 Odds Ratio Estimates

\begin{tabular}{|c|c|c|c|c|}
\hline Effect & OddsRatioEst & & LowerCL & UpperCL \\
\hline Total Assets & & 1 & 1 & 1 \\
\hline
\end{tabular}


be significant (at the $0.01 \%$ level) in determining whether a firm will or will not make a cash dividend distribution.

Panel 3 of Table 7 displays the Type 3 parameter estimates as well as the odds ratios. According to the sign of the estimates and odds ratios, a non-dividend paying firm is $117.48 \%$ more likely to not pay a dividend than a switcher firm. On the other hand, a dividend paying firm is $0.031 \%$ less likely to omit a dividend. If the economy is in an expansionary period, switcher firms are $0.767 \%$ less likely to omit a dividend in the coming period. The results imply that a non-dividend paying firm is $0.645 \%$ less likely to omit a dividend in an expansionary period. This is not really so counterintuitive. It makes sense that firms that were previously non-dividend payer will initiate dividend payments when economic conditions are optimal and prospects look promising.

Similar to findings in Table 4, dividend payers are $1.392 \%$ more likely to omit or discontinue cash dividends during an economic expansion. Reasons for this somewhat surprising outcome may relate to the damaging impacts of dividend omission during an economic recession. It may be that firms that can no longer sustain regular cash distributions choose to make this evident during more favorable economic times so as not to severely damage the firm.

As in the other models, a one unit increase in Total Assets is $1 \%$ less likely to be related to a lack of dividend payment in the next period.

The fifth model we test is

$$
\begin{aligned}
\operatorname{Pr}\left(\text { Payment }_{t}\right)= & \alpha+\beta_{1} \text { Nonpayer }+\beta_{2} \text { Payer }+\beta_{3} \text { Payer }+\beta_{4}{\text { Nonpayer } * \text { Expansion }_{t-1}+}+ \\
& \beta_{5} \text { Payer } * \text { Expansion } \text { Ex-1 }_{t-1}+\beta_{6} \text { Total Assets }_{t-1}+ \\
& \beta_{7} \text { GrowthOpportunity } 2_{t-1}+\beta_{8} \text { Profitability }_{t-1}
\end{aligned}
$$


The Status effect is represented by the two binary variables: Nonpayer and Payer. The binary variable "Nonpayer" is equal to 1 if the firm has not paid a regular cash dividend (distribution code "1232" in the CRSP database) within the previous 12 quarters, and it is equal to 0 otherwise. The binary variable "Payer" is equal to 1 if the firm has paid a regular cash dividend (distribution code "1232" in the CRSP database) in all of the previous 12 quarters, and it is equal to 0 otherwise. We measure the effect of the market according to the standard definition of a recession. The Economic Cycle effect is introduced as a binary variable called Expansion that is equal to 1 if GDP does not decline for two or more consecutive quarters and 0 otherwise. The Total Assets are reported in millions of US dollars and are equal to the book value of total assets. Growth Opportunities 2 is calculated as the percent change in assets over the quarter. Earned Equity is calculated as ratio of retained earnings to the book value of equity. Profitability 2 is calculated as the ratio of after-tax earnings to the book value of equity.

Each variable is added to the model one by one. Panels 1 through 5 of Table 8 display the results of the forward selection process. As in Model 2, the market conditions proxied by two consecutive quarters of GDP decline are not significant determinants as to whether a cash dividend payment will be made or not. The only statistically significant variables found in the forward selection process are Status and Total Assets. Panel 2 displays the Type 3 analysis of effects based on Wald tests, which indicate that Status and Total Assets are statistically significant at the $0.01 \%$ level.

Panel 3 displays the parameter estimates along with the odds ratios for each variable. According to the signs of the parameter estimates and the odds ratios, a nondividend paying firm is $265.33 \%$ times more likely than a switcher to omit a dividend 
Table 8

\section{Forward Selection Procedure With Growth Opportunities 2 and Profitability 2 and GDP Market Measure}

The probability modeled is that Payment $=$ 'No'. There were 309,742 instances between the first quarter of 1993 and the second quarter of 2010 in which firms did not pay a dividend. There were 111,420 instances between the first quarter of 1993 and the second quarter of 2010 in which firms paid a dividend. Using a binary logit model and Fisher's scoring optimizing technique, variables are selected using forward selection process. The Status effect is represented by the two binary variables: Nonpayer and Payer. The binary variable "Nonpayer" is equal to 1 if the firm has not paid a regular cash dividend (distribution code "1232" in the CRSP database) within the previous 12 quarters, and it is equal to 0 otherwise. The binary variable "Payer" is equal to 1 if the firm has paid a regular cash dividend (distribution code "1232" in the CRSP database) in all of the previous 12 quarters, and it is equal to 0 otherwise. We measure the effect of the market according to the standard definition of a recession. The Economic Cycle effect is introduced as a binary variable called Expansion that is equal to 1 if GDP declines for two or more consecutive quarters and 0 otherwise. The Total Assets are reported in millions of US dollars and are equal to the book value of total assets. Growth Opportunities 2 is calculated as the percent change in assets over the quarter. Earned Equity is calculated as ratio of retained earnings to the book value of equity. Profitability 2 is calculated as the ratio of after-tax earnings to the book value of equity.

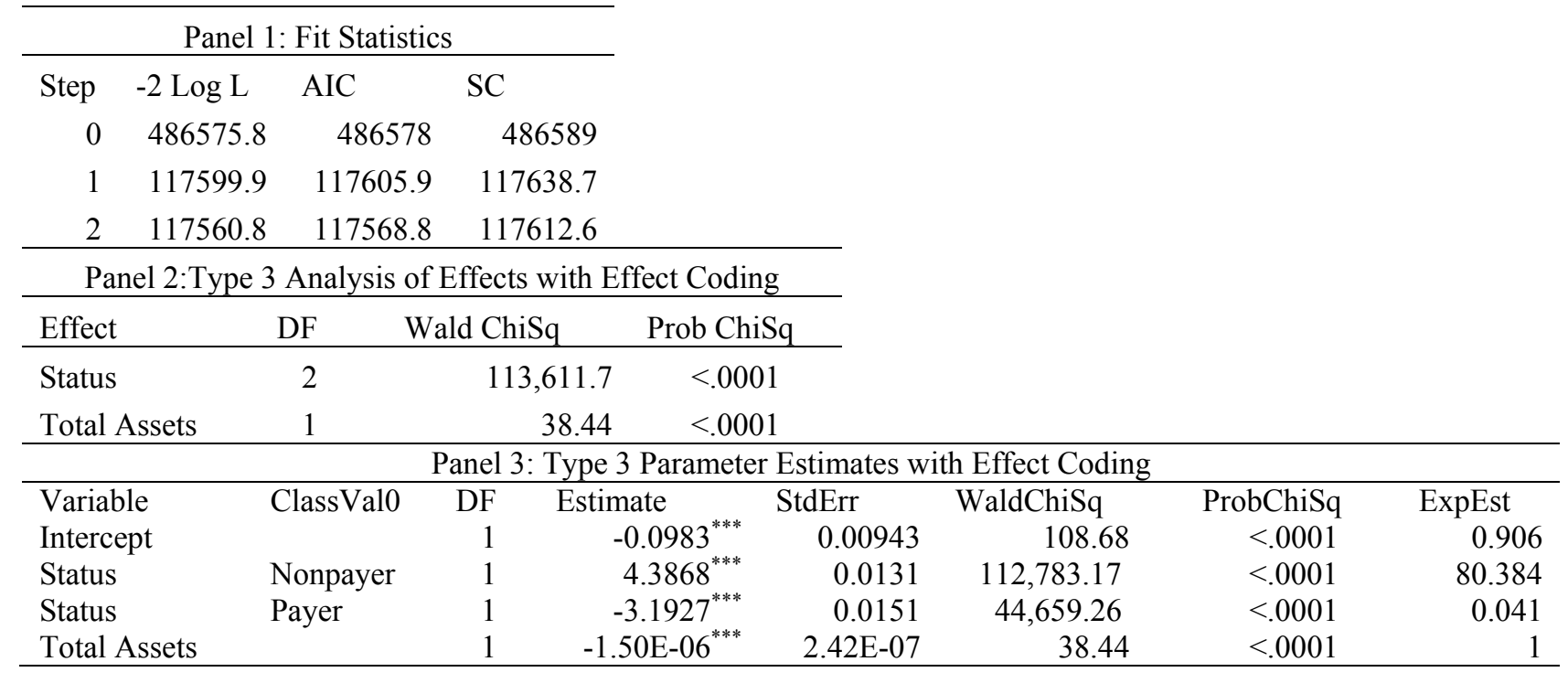


Table 8 (continued)

Forward Selection Procedure With Growth Opportunities 2 and Profitability 2 and GDP Market Measure

\begin{tabular}{|c|c|c|c|c|c|}
\hline \multicolumn{6}{|c|}{ Panel 4: Type 3 Odds Ratio Estimates } \\
\hline Effect & & & OddsRatioEst & LowerCL & UpperCL \\
\hline Status & Nont & yer vs Switcher & 265.329 & 255.575 & 275.454 \\
\hline Status & Paye & vs Switcher & 0.136 & 0.13 & 0.142 \\
\hline \multicolumn{3}{|c|}{ Total Assets } & 1 & 1 & 1 \\
\hline
\end{tabular}


Table 9

Forward Selection Procedure With Growth Opportunities 2 and Profitability 2 and S\&P 500 Market Measure

The probability modeled is that Payment $=$ 'No'. There were 309,742 instances between the first quarter of 1993 and the second quarter of 2010 in which firms did not pay a dividend. There were 111,420 instances between the first quarter of 1993 and the second quarter of 2010 in which firms paid a dividend. Using a binary logit model and Fisher's scoring optimizing technique, variables are selected using forward selection process. The Status effect is represented by the two binary variables: Nonpayer and Payer. The binary variable "Nonpayer" is equal to 1 if the firm has not paid a regular cash dividend (distribution code " 1232 " in the CRSP database) within the previous 12 quarters, and it is equal to 0 otherwise. The binary variable "Payer" is equal to 1 if the firm has paid a regular cash dividend (distribution code "1232" in the CRSP database) in all of the previous 12 quarters, and it is equal to 0 otherwise. We measure the effect of the market according to the return on the S\&P 500 from the previous quarter. The Total Assets are reported in millions of US dollars and are equal to the book value of total assets. Growth Opportunities 2 is calculated as the percent change in assets over the quarter. Earned Equity is calculated as ratio of retained earnings to the book value of equity. Profitability 2 is calculated as the ratio of after-tax earnings to the book value of equity.

\begin{tabular}{|c|c|c|c|c|c|c|c|c|c|}
\hline \multicolumn{6}{|c|}{ Panel 1: Fit Statistics } & & & & \\
\hline Step & $-2 \log \mathrm{L}$ & \multicolumn{3}{|c|}{ AIC } & $\mathrm{SC}$ & & & & \\
\hline 0 & $486,575.77$ & \multicolumn{3}{|c|}{$486,578.00$} & $486,589.00$ & & & & \\
\hline 1 & $117,599.86$ & \multicolumn{3}{|c|}{$117,605.86$} & $117,638.71$ & & & & \\
\hline 2 & $117,469.48$ & \multicolumn{3}{|c|}{$117,477.48$} & $117,521.28$ & & & & \\
\hline 3 & $117,432.22$ & \multicolumn{3}{|c|}{$117,442.22$} & $117,496.97$ & & & & \\
\hline \multicolumn{10}{|c|}{ Panel 2:Type 3 Analysis of Effects with Effect Coding } \\
\hline Effect & & DF & \multicolumn{2}{|c|}{ WaldChiSq } & ProbChiSq & & & & \\
\hline \multirow{2}{*}{\multicolumn{2}{|c|}{$\begin{array}{l}\text { Status } \\
\text { S\&P } 500 \text { Otr. Return }\end{array}$}} & 2 & \multicolumn{2}{|c|}{$113,209.18$} & $<.0001$ & & & & \\
\hline & & 1 & \multicolumn{2}{|r|}{128.29} & $<.0001$ & & & & \\
\hline \multicolumn{2}{|c|}{ Total Assets } & 1 & & 36.54 & $<.0001$ & & & & \\
\hline \multicolumn{10}{|c|}{ Panel 3: Type 3 Parameter Estimates with Effect Coding } \\
\hline \multicolumn{2}{|c|}{ Variable } & Cla & sVal0 & $\mathrm{DF}$ & Estimate & StdErr & WaldChiSq & ProbChiSq & ExpEst \\
\hline \multicolumn{2}{|c|}{ Intercept } & & & 1 & $-0.1222^{* * *}$ & 0.00967 & 159.53 & $<.0001$ & 0.885 \\
\hline \multicolumn{2}{|l|}{ Status } & No & payer & 1 & $4.3935^{* * * *}$ & 0.0131 & $112,405.06$ & $<.0001$ & 80.921 \\
\hline \multicolumn{2}{|l|}{ Status } & Pay & & 1 & $-3.1966^{* * *}$ & 0.0151 & $44,681.42$ & $<.0001$ & 0.041 \\
\hline \multicolumn{2}{|c|}{ S\&P 500 Qtr. Return } & & & 1 & $1.1383^{* * *}$ & 0.1005 & 128.29 & $<.0001$ & 3.121 \\
\hline \multicolumn{2}{|c|}{ Total Assets } & & & 1 & $-1.46 \mathrm{E}-06^{* * *}$ & $2.41 \mathrm{E}-07$ & 36.54 & $<.0001$ & 1 \\
\hline
\end{tabular}


Table 9 (continued)

Forward Selection Procedure With Growth Opportunities 2 and Profitability 2 and S\&P 500 Market Measure

\begin{tabular}{|c|c|c|c|c|}
\hline \multicolumn{5}{|c|}{ Panel 4: Type 3 Odds Ratio Estimates } \\
\hline Effect & & OddsRatioEst & LowerCL & UpperCL \\
\hline Status & Nonpayer vs Switcher & 267.822 & 257.947 & 278.074 \\
\hline Status & Payer vs Switcher & 0.135 & 0.129 & 0.142 \\
\hline \multicolumn{2}{|c|}{ S\&P 500 Qtr. Return } & 3.121 & 2.563 & 3.801 \\
\hline \multicolumn{2}{|c|}{ Total Assets } & 1 & 1 & 1 \\
\hline
\end{tabular}


in the coming quarter. A dividend payer, on the other hand, is $0.136 \%$ less likely than a switcher to omit a dividend in the coming quarter. Again, a one unit increase in total assets implies a $1 \%$ decrease in the likelihood that a firm will not pay a dividend. However, just as the previous models have shown, dividend payers are more likely to omit dividends during economic expansions, while nonpayers and switchers are less likely to omit during expansions.

The sixth model we test is

$$
\begin{aligned}
\operatorname{Pr}\left(\text { Payment }_{t}\right)= & \alpha+\beta_{1} \text { Nonpayer }+\beta_{2} \text { Payer }+\beta_{3} \text { S\&P500Ret }+\beta_{4} \text { Nonpayer } * \\
& \text { S\&P500Ret } t_{t-1}+\beta_{5} \text { Payer } * S \& P 500 \text { Ret }_{t-1}+\beta_{6} \text { Total Asset }_{t-1}+ \\
& \beta_{7} \text { GrowthOpportunity }_{t-1}+\beta_{8} \text { Profitability }_{t-1}
\end{aligned}
$$

The Status effect is represented by the two binary variables: Nonpayer and Payer. The binary variable "Nonpayer" is equal to 1 if the firm has not paid a regular cash dividend (distribution code "1232" in the CRSP database) within the previous 12 quarters, and it is equal to 0 otherwise. The binary variable "Payer" is equal to 1 if the firm has paid a regular cash dividend (distribution code "1232" in the CRSP database) in all of the previous 12 quarters, and it is equal to 0 otherwise. We measure the effect of the market according to the return on the S\&P 500 from the previous quarter. The Total Assets are reported in millions of US dollars and are equal to the book value of total assets. Growth Opportunities 2 is calculated as the percent change in assets over the quarter. Earned Equity is calculated as ratio of retained earnings to the book value of equity. Profitability 2 is calculated as the ratio of after-tax earnings to the book value of equity. 
Each variable is added to the model one by one. Panels 1 through 5 of Table 9 display the results of the forward selection process. Of the five variables in Model 6, only three of them are determined to be significant using forward selection: Status, S\&P 500 Return in the previous quarter, and Total Assets. Although this model excludes factors such Profitability and Growth Opportunities, it does imply that the dividend paying history of a firm as well as its size and opportunities for growth are likely to determine whether or not the firm will make a dividend payment in the following quarter. Panel 2 indicates that these factors are statistically significant at the $0.01 \%$ level.

Panel 3 displays the parameter estimates for Model 6, and Panel 4 displays the odds ratios. According to the estimates and the odds ratios, a non-dividend payer is $267.82 \%$ more likely than a switcher firm to omit a cash dividend in the next quarter. Conversely, a dividend payer is $0.135 \%$ less likely than a switcher firm to omit or suspend dividends in the next quarter.

A one unit increase in the S\&P 500 index return is associated with a $3.121 \%$ increase in the likelihood that a firm will not pay a dividend. This is a bit surprising as we would expect that good economic conditions would foster the likelihood of dividend payments. It may be that the S\&P500 quarterly return is not a complete measure of market conditions. Another explanation relates to findings in Tables 4 and 7. It may be that firms that cannot maintain regular dividend payment choose to omit or suspend them during good economic conditions, so as to mitigate the negative effects surrounding a dividend omission or suspension.

We also employ step wise selection to determine which variables serve as the best predictor variables. Table 10 displays the results of the stepwise analysis. According to 


\section{Table 10}

\section{Stepwise Selection Procedure With NBER Market Measure}

The probability modeled is that Payment $=$ 'No'. There were 309,742 instances between the first quarter of 1993 and the second quarter of 2010 in which firms did not pay a dividend. There were 111,420 instances between the first quarter of 1993 and the second quarter of 2010 in which firms paid a dividend. Using a binary logit model and Fisher's scoring optimizing technique, variables are selected using stepwise selection process. The Status effect is represented by the two binary variables: Nonpayer and Payer. The binary variable "Nonpayer" is equal to 1 if the firm has not paid a regular cash dividend (distribution code " 1232 " in the CRSP database) within the previous 12 quarters, and it is equal to 0 otherwise. The binary variable "Payer" is equal to 1 if the firm has paid a regular cash dividend (distribution code "1232" in the CRSP database) in all of the previous 12 quarters, and it is equal to 0 otherwise. We measure the effect of the market according to the expansion and contractions defined by the NBER. The Economic Cycle effect is introduced as a binary variable called Expansion that is equal to 1 if the market is in an expansionary quarter and 0 when the market is in a contraction or recession period. The Total Assets are reported in millions of US dollars and are equal to the book value of total assets. Growth Opportunities 1 is calculated as the ratio of the market value of total capital to the book value of total assets ((book value of total assets-book value of equity + market value of equity)/book value of total assets). Growth Opportunities 2 is calculated as the percent change in assets over the quarter. Earned Equity is calculated as ratio of retained earnings to the book value of equity. Profitability 1 is calculated as the ratio of earnings before interest to the book value of total assets. Profitability 2 is calculated as the ratio of after-tax earnings to the book value of equity.

\begin{tabular}{crrr}
\hline \multicolumn{4}{c}{ Panel 1: Fit Statistics } \\
\hline Step & \multicolumn{1}{c}{$-2 \log$ L } & \multicolumn{1}{c}{ AIC } & \multicolumn{1}{c}{ SC } \\
\hline 0 & 486,576 & 486,578 & 486,589 \\
1 & $117,599.86$ & $117,605.86$ & $117,638.71$ \\
2 & $117,354.46$ & $117,362.46$ & $117,406.26$ \\
3 & $117,070.09$ & $117,082.09$ & $117,147.79$ \\
4 & $117,028.98$ & $117,042.98$ & $117,119.64$ \\
5 & $116,915.77$ & $116,931.77$ & $117,019.37$ \\
6 & $116,874.57$ & $116,892.57$ & $116,991.13$ \\
7 & $116,668.04$ & $116,688.04$ & $116,797.54$ \\
8 & $116,874.57$ & $116,892.57$ & $116,991.13$ \\
\hline
\end{tabular}


Table 10 (continued)

Stepwise Selection Procedure With NBER Market Measure

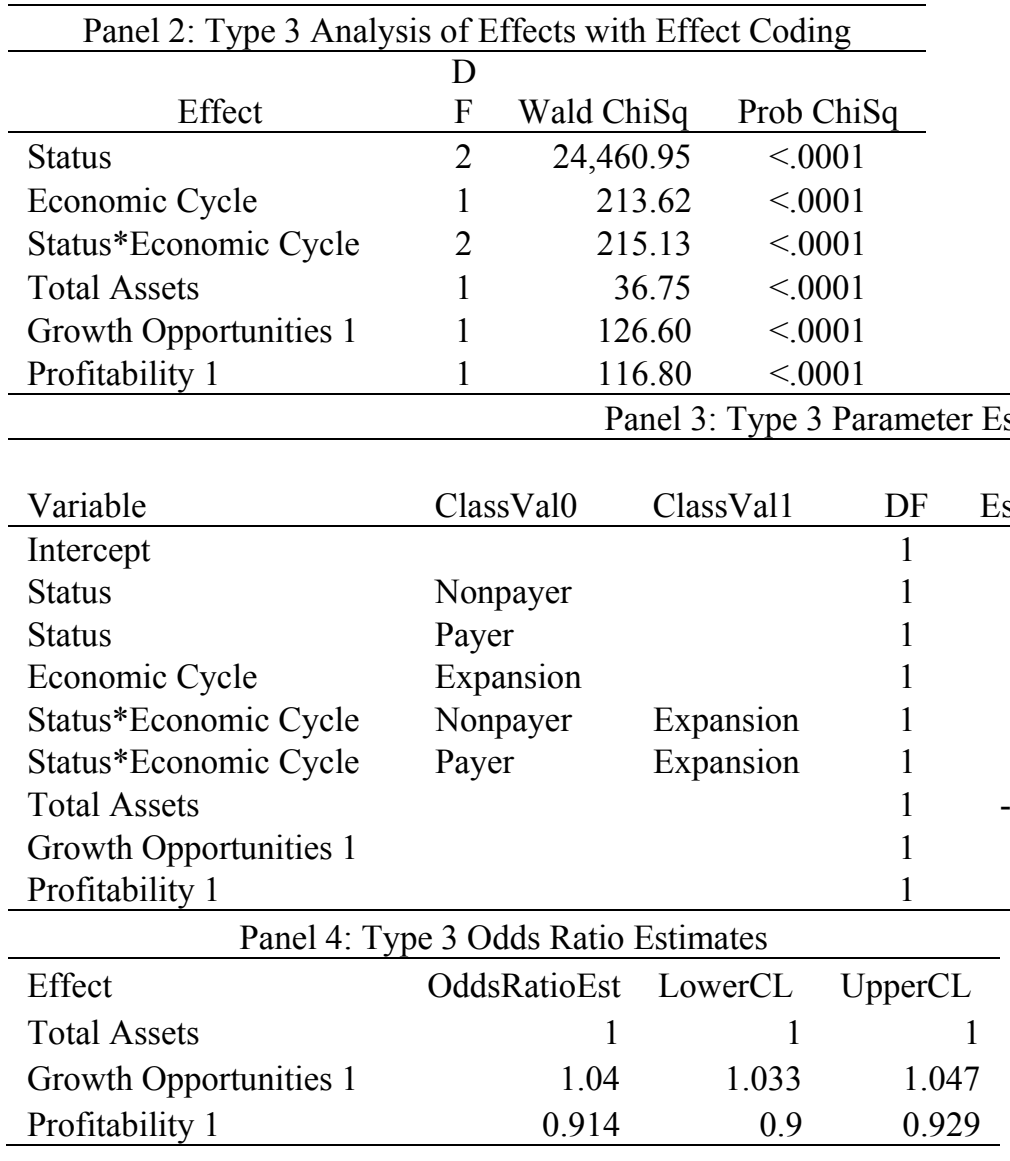


Panel 2, the variables that serve as the best predictors are dividend paying status, economic cycle, the interaction term between Status and Economic Cycle, Total Assets, Growth Opportunities 1, and Profitability 1. Parameter estimates and odds ratios are shown in Panels 3 and 4. Non-dividend payers are 114\% more likely than switchers to not pay a dividend in the next quarter, while regular dividend payers are $0.03 \%$ less likely to pay a dividend than switcher firms. During an economic expansion, firms are $0.765 \%$ less likely to omit or suspend dividend payments than they are in a recession. During an expansion, non-dividend paying firms are $0.644 \%$ less likely, than a switcher, to not pay a dividend. Corroborating preliminary findings in Table 3, dividend payers are $1.393 \%$ more likely than switcher firms to discontinue or omit dividends during an expansion. As in the previous models, a one unit increase in Total Assets is associated with a 1\% decrease in the likelihood that a firm will not pay a dividend. A one unit increase in Growth Opportunities 1 increases the likelihood that a firm will not pay a dividend. On the other hand, a one unit increase in profitability decreases the likelihood that a firm will not pay a dividend by $0.914 \%$.

\subsection{Summary and Conclusions}

Previous studies that concern dividend payments relate dividend payments to earnings, size, and growth opportunities. More recent literature finds that the relation between dividends and earnings is deteriorating. Managers have admitted their reluctance to deviate from their dividend paying history. Those firms that pay dividends continue to do so because these firms have historically paid dividends regularly and managers feel obligated to continue those cash distributions. Repurchases have become the new way to distribute earnings. 
This begs the question as to whether a firm's dividend paying history can be used to determine the likelihood of future dividend payments.

The recent financial crisis brought on announcements of dividend reductions and suspensions, so we also investigate the possibility that the state of the economy affects a firm's likelihood of distributing dividends.

This study has found that firms perceived as dividend payers are likely to continue to pay dividends, while firms that do not have a history of paying cash dividends are not likely to begin dividend payments. In times of expansion, switcher firms are more likely to pay dividends than when a recession is occurring. Non-dividend payers are more likely to initiate dividends in an expansion than in a recession. Surprisingly, all models found that dividend payers are more likely to omit a dividend during an expansionary period. Although this seems surprising at first glance, managers are reluctant to change dividend policy, and pay dividends out of a feeling of obligation. If firms are not able to sustain dividend payments in the long run, it seems a better strategy for the manager to announce dividend omissions or suspensions during relatively healthy economic circumstances. This new and counterintuitive finding has not been documented in previous literature and is an important contribution of this dissertation. 


\section{CHAPTER 3: DETERMINANTS OF DIVIDEND INCREASES OR DECREASES OF U.S. STOCKS AND THE EFFECTS ON RETURNS}

\subsection{Introduction}

Examination of typical dividend paying firm will reveal that dividends are paid quarterly and the amount of cash dividend per share does not fluctuate, in fact it usually remains at the same level for very long periods of time. In most cases, a dividend paying firm has a very long history of paying dividends. Brav, Graham, Harvey, and Michaely (2005) find that most regular, dividend-paying firms continue to pay dividends because they feel obligated to do so due to their long history of paying dividends. In fact, they no longer adhere to target dividend payout ratios, instead they rely on past dividend levels when determining the firm's distribution policy.

Many studies have found a decreasing number of dividend paying firms (Skinner (2008); DeAngelo, DeAngelo, and Skinner (2004); Fama and French (2001)). Instead of cash dividends, more and more firms are using stock repurchases.

However, if regular-dividend paying firms are relying on past dividend levels in determining the firm's distribution policy, then a change in the dividend level of these firms should imply important information about the firm itself. This is especially true when investors are uncertain about future market conditions. The recent market downturn also increased uncertainty, implying that any dividend changes indicate fundamental changes of important consequences for the firm's future.

During the recent financial crisis, in addition to the free fall in stock prices, the financial news was filled with reports of decreasing dividends. In some cases, companies even suspended dividends. Prior literature has established that dividends convey 
information about future firm prospects (see, for instance, Lee (1996)). Thus, there seemed to be more bad news for stock prices in the downturn spirals.

The grim dividend news may have been pushing stock prices down further. Lee (1995) found that stock prices respond strongly to temporary shocks to dividends. Investors cannot distinguish the temporary shock components from the permanent ones, so they tend to consider temporary components as permanent components, creating a strong reaction to temporary dividend shocks.

Previous literature has also pointed to fundamental changes in firms. The number of firms paying dividends has declined dramatically since the 1970s (DeAngelo, DeAngelo, \& Skinner, 2000; DeAngelo, DeAngelo, \& Skinner, 2004; Hayn, 1995; Graham, Koski, \& Loewenstein, 2006). Instead, firms that are distributing earnings are using stock repurchases that became popular in the 1980s (Skinner, 2008). The current financial crisis is sure to bring about further changes in the fundamentals, which should be reflected in the dividend distributions, but the relatively small number of regular dividend payers makes Litner's (1956) findings more important. He notes that managers are reluctant to change regular cash dividends because a dividend decrease in the future will have negative effects for the firm. Therefore, any change in the firm's dividend level is of great consequence, and should reveal significant information.

More recently, Fuller and Blau (2010) find evidence of signaling in dividend paying firms. They find the firms perceived as high quality firms due to their previous earnings pay dividends to eliminate the free cash flow problem, while firms that are perceived as low quality because of low earning in previous periods pay small dividends. However, firms that are perceived as intermediate quality firms, pay higher dividends 
than firms perceived as high quality firms. The evidence suggests that healthy firms with intermediate earnings are attempting to distinguish themselves from poor quality firms.

In this chapter, we will divide firms into dividend paying, non-dividend paying, and switchers. We will investigate the relation between dividends and stock prices in each group and among the groups. The questions that will be answered in this study are as follows: What is the reaction of firms around the world to the current crisis? Have firms become fundamentally different as a result of the crisis? Are firms reducing their dividends because of current losses and persistent earnings problems? If so, are dividend reductions decreasing their stock prices? Have the investors been giving preference to holding dividend paying stocks in anticipation that during the downturn such stocks may hold up better in terms of their prices?

The remainder of this chapter is organized as follows: Section 3.2 provides a brief review of literature. Section 3.3 contains a brief description of the data. Section 3.4 presents the methodology. Section 3.5 discusses the results. The last section summarizes the findings and concludes.

\subsection{Review of Literature}

Lee (1996) decomposes dividends into temporary and permanent components and finds that dividends are only affected by the permanent component of earnings. He asserts that changes in dividends anticipate changes in permanent earnings, so dividends convey information about future firm prospects. In addition, investors react strongly to temporary dividend shocks because they cannot distinguish between temporary and permanent components. This position is supported by previous literature, which finds that persistent earnings problems cause reductions in dividends. DeAngelo, DeAngelo, and 
Skinner (1992) found that 50.9\% of NYSE firms with reported losses during 1980-1985 reduced dividends.

The composition of dividends themselves is also changing. Skinner (2008) points out the substitution effect between dividends and repurchases that began emerging in the 1980s for the U.S. firms. Using Lintner model regressions, Skinner (2008) finds the relation between repurchases and earnings becomes stronger over time, while the relation between dividends and earnings weakens over time.

DeAngelo, DeAngelo, and Skinner (2004) find that although aggregate dividends distributed by firms are increasing, the number of firms that are paying out dividends is actually decreasing. This implies that dividends are concentrated to a few firms. They find that about half of dividends reported in Compustat for the year 2000 were paid out by top 25 earning firms. In their earlier paper (2000), they show that special dividends have been disappearing since the 1960s. DeAngelo, DeAngelo, and Stulz (2006), Fama and French (2001), and Skinner (2008) also observe similar declines in dividend paying firms. Related to this position, Hayn (1995) finds that the earnings of firms have changed in recent times. The frequency and magnitude of losses has increased so that earnings are more volatile. Firms are fundamentally different, and a difference in fundamentals manifests itself as a difference in firm distributions.

Graham, Koski, and Loewenstein (2006) examine liquidity, volume, price volatility, adverse selection, and price impact for very anticipated, anticipated, and unanticipated events, particularly dividend announcements. They look at two samples of firms: Firms that announce they will begin paying dividends, and firms that regularly (predictably) make quarterly dividend announcements. Examining the period between 
1990 and 1998 and using CRSP data, LexisNexis announcements, Dow Jones News Retrieval, and the Wall Street Journal Index, they find that for very predictable events, liquidity and volume increase before the event, and liquidity returns to normal levels after the event. After the event, they do not find evidence of asymmetric information. For anticipated events, there is some evidence that the spread remains wider after the announcement, which implies asymmetric information. For unanticipated events, the evidence of asymmetric information prior to the event is more evident. The data shows a decline in adverse information and price volatility after the event. The spread widens, depth shrinks, and volume is high, implying that information is being priced and portfolios are being rebalanced. Contrary to previous literature, they do not find information asymmetry effects in stocks predominantly held by institutional investors.

Graham, Koski, and Loewenstein (2006) point out that the increased activity after a dividend initiation announcement implies that the firm is fundamentally different. This may be what leads to the increase in trading, which reflects portfolio rebalancing and possibly purchases by institutional investors. A reverse process may be observed in the market downturn spiral in the Fall of 2008, which was a surprise to most. Many firms were fundamentally changed by the financial crisis. Many firms announced dividend suspensions or decreases. By extension, the surprise declining dividend announcements may be followed by large institutional investor sell- offs.

Graham, Koski, and Loewenstein (2006) also find that high content information, even if the event was anticipated, leads to high volume and spreads and a decrease in liquidity after the event occurs. Although the market downturn was a surprise, there was a lot of information revealed regarding firms and the market. Volatility was, and still is, at 
historically high levels, volume and spreads are high, and liquidity is low. At this time, announcements that dividends are being suspended or decreased are very high content information, and signal that the firm is fundamentally different.

Few studies have examined dividend changes and their effects on returns. Li and Lie (2006) expand the catering theory hypothesis of Baker and Wurgler (2004) to explain changes in dividends. They find that managers are influenced by investor demands for dividends. When the dividend premium is high, dividend initiations increase, while a low dividend premium is associated with dividend omissions. They do find some evidence that dividend increases are related to high dividend premiums, while dividend decreases are related to low dividend premiums, but the evidence is statistically weak. Another problem with the study is that the measure of dividend premium (measured as the log difference between the value weighted market to book value on dividend paying firms and non-dividend paying firms) is measured at the beginning of the year, while dividends are paid quarterly. The study does cover a large time span $(1963-2000)$ and includes controls for firm specific factors such as dividend yield, size, and various fundamental ratios, but it does not control for structural breaks, nor does it take into account the state of the economy. The literature has shown fundamental changes in firms, as well as in their dividend policies and returns, during the 1960s and the 1980s, and the state of the economy has fluctuated dramatically during the sample period. These factors may be important determinants of dividend policy changes, and may explain the irregular dividend increase pattern observed in Li and Lie (2006) after the 1980s.

Benartzi, Michaely, and Thaler (1997) find evidence against the signaling theory using dividend changes. They find instead that dividend changes simply signal 
information about what has happened, namely increases in permanent earnings. What is surprising is that they observe negative future earnings in firms that have increased dividends. The positive relation between dividend changes and future earnings is insignificant despite a large number of control variables. Other studies also fail to find a relation between dividend changes and future earnings (Watts, 1973; Gonedes, 1978, Penman, 1983, and others).

Grullon, Michaely, and Swaminathan (2002) use return on assets as a measure of profitability to examine firm characteristics related to dividend changes. Their results also strongly conflict with the signaling theory, but support the life cycle hypothesis. Like Benartzi, Michaely, and Thaler (1997) and others, they fail to find a relation between dividend changes and future earnings. In fact, they find that dividend increasing (decreasing) firms exhibit higher (lower) profitability prior to the dividend increase (decrease), but profitability declines (recovers) in the years following the announcement. This study is the first we know of to relate the dividend increase (decrease) to the firm's decrease (increase) in cost of capital. They use the Fama and French three-factor model to characterize dividend increasing firms from decreasing firms before and after dividend changes. Their study period is also quite long, and structural breaks or market cycles are not controlled for. Although they attempt to control for profitability, given the recent study by Fuller and Blau (2010), it would seem that a more appropriate control for profitability would involve creating groups of high profit, intermediate profit, and low profit firms.

The findings against the signaling theory in Benartzi, Michaely, and Thaler (1997) and Grullon, Michaely, and Swaminathan (2002) seem very strong, but they may 
be related to the fact that in measuring profitability, they adjusted for drift, but did not address measurement error associated with their adjustment for drift on profitability, nor did they address the omitted correlated variables that should control for expected changes in future earnings (Nissim and Ziv, 2001). Contrary to their findings, Brickley (1983), Aharony and Dotan (1994), Nissim and Ziv (2001), as well as others find that dividend changes are related to future earnings. They find that increases in earnings continue in to the following year.

Koch and Sun (2004) also examine dividend changes, but relate them to earnings. Their results imply that reactions to dividend changes may be delayed reactions to recent earnings announcements. They find that dividends convey information to investors. They relate information regarding the persistence of past earnings. If management expects earnings increases to continue, an increase in dividends may signal this information to the market, and investors will revise their expectations creating positive abnormal returns. On the other hand, if dividend changes contradict previous earnings, the market will experience a reversal. These findings are of interest because most recent dividend literature discounts the relation between earnings and dividends. It seems that although the relation between earnings and repurchases has become stronger (Skinner, 2008), repurchases may convey short-term information about the firm, while cash dividend changes convey fundamental changes in the firm itself.

\subsection{Data}

The data for this study comes from the Center for Research in Security Prices (CRSP) and Compustat database. Quarterly returns data for all securities in the CRSP database are gathered for the 1990-2009 calendar years. In order to classify firms as 
dividend payers, non-dividend payers, or "switchers," data is gathered on annual dividends for the period 1990 - 2009 from CRSP.

As in Chapter 1, firms are identified as dividend payers, non-dividend payers, and "switcher" firms based on their dividend paying history in the previous twelve quarters. Firms identified as dividend payers have paid a regular, quarterly, cash dividend in all of the previous twelve quarters. We identify these distributions using the CRSP database code "1232." Firms that have not paid a single regular, quarterly, cash dividend in the previous twelve quarters are labeled as non-dividend payers. Switcher firms are those that paid regular, quarterly, cash dividends within the previous twelve quarters, but did not distribute dividends in every quarter.

Data on firm fundamentals and information from financial statements are obtained from the Compustat database. This data is used to sort returns into portfolios and develop the quarterly factors SMB and HML from the Fama and French three-factor model, as described in the methodology section.

In order to determine whether dividends mattered during the 2008 market downturn, we have to examine whether the three types of firms (dividend paying, nondividend paying, and switchers) are different based on their returns. This has important implications for investors. In particular, we would like to investigate which one of the three groups of firm stocks may hold up better in terms of their prices during a downturn spiral. In order to proxy the state of the economy we use NBER classifications of recessions and expansions. 


\subsection{Methodology}

One of the main contributions of this study is to determine if the state of the economy matters in determining dividend distribution changes. Such investigation has been rare since downturn spirals have been historically few in the US financial markets.

Table 11 shows how rare dividend changes are. Of the 117,722 dividends paid throughout our sample period, only 4,757 of them were lower than the previous dividend. During this same time period, there were 19,917 instances were dividend levels were increased, but in almost $80 \%$ of cases, dividend levels did not change from the previous quarter. There were a number of firms that were classified as nonpayers, but began paying dividends. They are included in this table as "nonpayers." It is notable that these nonpayer firms that initiated dividends have a higher likelihood of decreasing dividends, while switcher firms have a higher likelihood of increasing dividends.

Table 12 shows how dividend levels have changes over the course of our study period. Not much can be said of the number of decreases or increases of non-dividend payers during economic recessions, as there were very few in each quarter. On the other hand, dividend payers saw a decline in dividend level decreases and increases during the recession of 2001. This is consistent with the idea that managers are reluctant to change

Table 11

Number of Dividend Changes (1993Q1 - 2009Q2)

Firms are identified as non-dividend payers if they have not paid a regular cash dividend (distribution code "1232" in the CRSP database) within the last 12 quarters. Firms are identified as dividend payers if they paid a regular cash dividend in the previous 12 quarters. If a firm has paid dividends irregularly within the most recent 12 quarters, it is identified as a "Switcher" firm.

\begin{tabular}{ccccccc}
\hline Status & Decrease & \multicolumn{3}{c}{ Increase } & \multicolumn{3}{c}{ No Change } \\
\hline Nonpayer & 210 & $6.56 \%$ & 556 & $17.36 \%$ & 2,437 & $76.08 \%$ \\
Payer & 2,754 & $3.88 \%$ & 11,322 & $15.93 \%$ & 56,982 & $80.19 \%$ \\
Switcher & 1,793 & $4.13 \%$ & 8,039 & $18.50 \%$ & 33,629 & $77.38 \%$ \\
\hline
\end{tabular}


dividend payment policies. However, the recession in late 2007 paints a different picture. Dividend decreases increase dramatically as the recession gets deeper. The number of decreases almost doubles between the fall and winter of 2008. Dividend increases also show signs of a recession. They experience a serious drop off as the recession deepens. The pattern for switcher firms is similar to that of regular dividend paying firms.

We employ a logistic regression analysis in order to identify the determinants of dividend changes. We model the probability that the dividend will increase, decrease, or not change. The factors recognized by previous literature include earnings, profitability, and size. We include these in our model. We also include a binary variable to control for economic conditions, as well as the firms' dividend paying status.

Previous literature on dividend paying firm characteristics has established that dividend paying firms tend to be of large size. Market value and book equity are also found to be related to the propensity to pay dividends. That being the case, we felt it appropriate to use the Fama-French three-factor model in examining excess returns across dividend paying groups. We also use the Fama-French three-factor model in examining excess returns before and during the downturn to see if changes have occurred in the relations between excess return and the market, size, and book-to-market factors:

$$
r_{i}=a_{i}+b_{i}\left(R_{m}-R_{f}\right)+s_{i} S M B+h_{i} H M L+e_{i}
$$

Where $r_{i}$ is the return on portfolio $i, R_{f}$ is the T-bill rate, and $R_{m}$ is the market return proxied by the return on the CRSP value-weighted index. Six size-BM portfolios are formed in June of each year to create the SMB and HML factors. The SMB factor is calculated as the difference between the average return on the three small size portfolios and the three big size portfolios. The HML factor is calculated as the difference between 
Table 12

\section{Number of Dividend Changes Over Time (1993Q1 - 2009Q2)}

Firms are identified as non-dividend payers if they have not paid a regular cash dividend (distribution code "1232" in the CRSP database) within the last 12 quarters. Firms are identified as dividend payers if they paid a regular cash dividend in the previous 12 quarters. If a firm has paid dividends irregularly within the most recent 12 quarters, it is identified as a "Switcher" firm.

\begin{tabular}{|c|c|c|c|c|c|c|c|}
\hline \multicolumn{8}{|c|}{ Panel 1: Dividend Changes for Non-Dividend Payers } \\
\hline $\begin{array}{l}\text { Year \& } \\
\text { Quarter }\end{array}$ & Decrease & Increase & \begin{tabular}{|l|} 
No \\
Change
\end{tabular} & $\begin{array}{l}\text { Year \& } \\
\text { Quarter }\end{array}$ & Decrease & Increase & $\begin{array}{l}\text { No } \\
\text { Change }\end{array}$ \\
\hline 1993Q1 & 1 & 4 & 15 & 2001Q2 & 1 & 3 & 5 \\
\hline 1993Q2 & & 3 & 15 & 2001Q3 & 1 & 1 & 7 \\
\hline 1993Q3 & & & & 2001Q4 & 29 & 85 & 529 \\
\hline 1993Q4 & 6 & 6 & 6 & 2002Q1 & & 3 & 7 \\
\hline 1994Q1 & 2 & 10 & 22 & 2002Q2 & & & 5 \\
\hline 1994Q2 & 5 & 5 & 36 & 2002Q3 & 30 & 135 & 726 \\
\hline 1994Q3 & 32 & 120 & 580 & 2002Q4 & 1 & & 10 \\
\hline 1994Q4 & 2 & 4 & 21 & 2003Q1 & 2 & 5 & 6 \\
\hline 1995Q1 & 8 & 2 & 18 & 2003Q2 & 2 & 2 & 7 \\
\hline 1995Q2 & 3 & 7 & 18 & 2003Q3 & 5 & 8 & 13 \\
\hline 1995Q3 & 4 & 1 & 6 & 2003Q4 & 1 & 3 & 24 \\
\hline 1995Q4 & 5 & 5 & 13 & 2004Q1 & 1 & 5 & 17 \\
\hline 1996Q1 & 6 & 8 & 5 & 2004Q2 & 5 & 5 & 14 \\
\hline 1996Q2 & 2 & 7 & 15 & 2004Q3 & 1 & 3 & 11 \\
\hline 1996Q3 & 1 & & 13 & 2004Q4 & 1 & 6 & 12 \\
\hline 1996Q4 & 4 & 3 & 11 & 2005Q1 & 2 & 10 & 14 \\
\hline 1997Q1 & 4 & 1 & 7 & $2005 \mathrm{Q} 2$ & 3 & 10 & 24 \\
\hline 1997Q2 & 2 & 2 & 13 & 2005Q3 & 2 & 2 & 7 \\
\hline 1997Q3 & 2 & 3 & 5 & 2005Q4 & 1 & 8 & 5 \\
\hline 1997Q4 & 1 & 4 & 10 & 2006Q1 & & 4 & 10 \\
\hline 1998Q1 & 2 & 6 & 5 & 2006Q2 & & 3 & 11 \\
\hline 1998Q2 & 4 & 2 & 11 & 2006Q3 & 2 & 2 & 7 \\
\hline 1998Q3 & 1 & 2 & 6 & 2006Q4 & & 3 & 3 \\
\hline 1998Q4 & 1 & 2 & 12 & 2007Q1 & 2 & 5 & 2 \\
\hline 1999Q1 & & 1 & 10 & 2007Q2 & 1 & 2 & 12 \\
\hline 1999Q2 & 1 & 3 & 16 & $2007 \mathrm{Q} 3$ & 3 & 2 & 7 \\
\hline 1999Q3 & 1 & 1 & 7 & 2007Q4 & 4 & 4 & 8 \\
\hline 1999Q4 & & 4 & 4 & 2008Q1 & 3 & 6 & 7 \\
\hline 2000Q1 & 1 & 3 & 2 & 2008Q2 & 1 & 1 & 6 \\
\hline 2000Q2 & 1 & 1 & 1 & 2008Q3 & & 3 & 3 \\
\hline 2000Q3 & & 2 & 3 & 2008Q4 & 1 & 1 & \\
\hline 2000Q4 & 1 & 1 & 1 & 2009Q1 & 1 & & 3 \\
\hline 2001Q1 & & & 2 & 2009Q2 & 2 & & 1 \\
\hline
\end{tabular}


Table 12 (continued)

\begin{tabular}{|c|c|c|c|c|c|c|c|}
\hline \multicolumn{8}{|c|}{ Panel 2: Dividend Changes for Dividend Payers } \\
\hline $\begin{array}{l}\text { Year \& } \\
\text { Quarter }\end{array}$ & Decrease & Increase & $\begin{array}{l}\text { No } \\
\text { Change }\end{array}$ & \begin{tabular}{|l|} 
Year \& \\
Quarter
\end{tabular} & Decrease & Increase & $\begin{array}{l}\text { No } \\
\text { Change }\end{array}$ \\
\hline 1993Q1 & 35 & 143 & 596 & 2001Q2 & 10 & 49 & 484 \\
\hline 1993Q2 & 45 & 156 & 941 & 2001Q3 & 13 & 55 & 513 \\
\hline 1993Q3 & 47 & 140 & 899 & 2001Q4 & & & \\
\hline 1993Q4 & 63 & 201 & 1000 & 2002Q1 & 24 & 122 & 513 \\
\hline 1994Q1 & 61 & 225 & 988 & 2002Q2 & 22 & 81 & 579 \\
\hline 1994Q2 & 46 & 180 & 1059 & \begin{tabular}{|l|} 
2002Q3 \\
\end{tabular} & 22 & 74 & 576 \\
\hline 1994Q3 & 31 & 178 & 1048 & \begin{tabular}{|l|}
$2002 Q 4$ \\
\end{tabular} & 16 & 115 & 570 \\
\hline 1994Q4 & 33 & 209 & 1016 & 2003Q1 & 12 & 162 & 554 \\
\hline 1995Q1 & 34 & 250 & 1030 & 2003Q2 & 22 & 99 & 681 \\
\hline 1995Q2 & 42 & 213 & 1119 & 2003Q3 & 18 & 150 & 633 \\
\hline 1995Q3 & 33 & 179 & 1157 & 2003Q4 & 30 & 171 & 755 \\
\hline 1995Q4 & 52 & 222 & 1065 & 2004Q1 & 41 & 228 & 746 \\
\hline 1996Q1 & 55 & 256 & 1061 & 2004Q2 & 43 & 170 & 933 \\
\hline 1996Q2 & 57 & 220 & 1140 & 2004Q3 & 35 & 193 & 994 \\
\hline 1996Q3 & 49 & 174 & 1184 & 2004Q4 & 38 & 217 & 984 \\
\hline 1996Q4 & 36 & 255 & 1106 & \begin{tabular}{|l|} 
2005Q1 \\
\end{tabular} & 38 & 299 & 939 \\
\hline 1997Q1 & 51 & 297 & 1080 & 2005Q2 & 56 & 205 & 981 \\
\hline 1997Q2 & 74 & 188 & 1144 & 2005Q3 & 35 & 179 & 1018 \\
\hline 1997Q3 & 73 & 196 & 1072 & 2005Q4 & 28 & 231 & 958 \\
\hline 1997Q4 & 84 & 213 & 924 & 2006Q1 & 25 & 311 & 908 \\
\hline 1998Q1 & 62 & 198 & 767 & 2006Q2 & 45 & 236 & 999 \\
\hline 1998Q2 & 72 & 107 & 662 & \begin{tabular}{|l|} 
2006Q3 \\
\end{tabular} & 50 & 188 & 1018 \\
\hline 1998Q3 & 56 & 112 & 676 & 2006Q4 & 23 & 239 & 1029 \\
\hline 1998Q4 & 30 & 108 & 595 & 2007Q1 & 28 & 315 & 941 \\
\hline 1999Q1 & 23 & 150 & 564 & 2007Q2 & 29 & 230 & 1055 \\
\hline 1999Q2 & 25 & 95 & 590 & 2007Q3 & 21 & 200 & 1051 \\
\hline 1999Q3 & 33 & 93 & 568 & 2007Q4 & 26 & 221 & 1037 \\
\hline 1999Q4 & 17 & 85 & 536 & 2008Q1 & 45 & 269 & 962 \\
\hline 2000Q1 & 11 & 126 & 491 & 2008Q2 & 50 & 194 & 1084 \\
\hline 2000Q2 & 16 & 72 & 502 & \begin{tabular}{|l|} 
2008Q3 \\
\end{tabular} & 55 & 160 & 1050 \\
\hline 2000Q3 & 7 & 48 & 443 & 2008Q4 & 91 & 130 & 998 \\
\hline 2000Q4 & 13 & 55 & 359 & 2009Q1 & 156 & 116 & 903 \\
\hline 2001Q1 & 13 & 86 & 397 & 2009Q2 & 135 & 87 & 935 \\
\hline
\end{tabular}


Table 12 (continued)

\begin{tabular}{|c|c|c|c|c|c|c|c|}
\hline \multicolumn{8}{|c|}{ Panel 3: Dividend Changes for Switchers } \\
\hline $\begin{array}{l}\text { Year \& } \\
\text { Quarter }\end{array}$ & Decrease & Increase & $\begin{array}{l}\text { No } \\
\text { Change }\end{array}$ & $\begin{array}{l}\text { Year \& } \\
\text { Quarter }\end{array}$ & Decrease & Increase & $\begin{array}{l}\text { No } \\
\text { Change }\end{array}$ \\
\hline 1993Q1 & 44 & 99 & 533 & 2001Q2 & 40 & 185 & 827 \\
\hline 1993Q2 & 23 & 42 & 346 & 2001Q3 & 33 & 122 & 843 \\
\hline 1993Q3 & 23 & 59 & 409 & 2001Q4 & 37 & 147 & 752 \\
\hline 1993Q4 & 27 & 106 & 434 & 2002Q1 & 31 & 180 & 705 \\
\hline 1994Q1 & 27 & 142 & 399 & 2002Q2 & 40 & 140 & 751 \\
\hline 1994Q2 & & 107 & 541 & 2002Q3 & & & \\
\hline 1994Q3 & 20 & & & 2002Q4 & 24 & 155 & 682 \\
\hline 1994Q4 & 27 & 141 & 523 & 2003Q1 & 30 & 175 & 632 \\
\hline 1995Q1 & 33 & 177 & 530 & 2003Q2 & 17 & 148 & 627 \\
\hline 1995Q2 & 24 & 107 & 577 & 2003Q3 & 28 & 156 & 598 \\
\hline 1995Q3 & 19 & 138 & 555 & 2003Q4 & 30 & 120 & 505 \\
\hline 1995Q4 & 21 & 131 & 548 & 2004Q1 & 22 & 135 & 454 \\
\hline 1996Q1 & 18 & 162 & 433 & \begin{tabular}{|l|} 
2004Q2 \\
\end{tabular} & 15 & 93 & 425 \\
\hline 1996Q2 & 30 & 111 & 504 & 2004Q3 & 13 & 103 & 340 \\
\hline 1996Q3 & 26 & 101 & 508 & 2004Q4 & 15 & 86 & 314 \\
\hline 1996Q4 & 17 & 129 & 498 & \begin{tabular}{|l|} 
2005Q1 \\
\end{tabular} & 16 & 136 & 321 \\
\hline 1997Q1 & 18 & 131 & 433 & 2005Q2 & 19 & 102 & 360 \\
\hline 1997Q2 & 29 & 82 & 447 & 2005Q3 & 22 & 104 & 395 \\
\hline 1997Q3 & 16 & 93 & 450 & 2005Q4 & 23 & 109 & 409 \\
\hline 1997Q4 & 48 & 83 & 370 & 2006Q1 & 15 & 135 & 366 \\
\hline 1998Q1 & 49 & 143 & 399 & 2006Q2 & 20 & 105 & 392 \\
\hline 1998Q2 & 84 & 139 & 542 & 2006Q3 & 17 & 81 & 406 \\
\hline 1998Q3 & 73 & 143 & 741 & 2006Q4 & 10 & 111 & 366 \\
\hline 1998Q4 & 51 & 223 & 810 & 2007Q1 & 15 & 127 & 285 \\
\hline 1999Q1 & 41 & 208 & 823 & 2007Q2 & 14 & 101 & 310 \\
\hline 1999Q2 & 45 & 173 & 885 & \begin{tabular}{|l|}
$2007 Q 3$ \\
\end{tabular} & 6 & 86 & 343 \\
\hline 1999Q3 & 24 & 116 & 908 & 2007Q4 & 13 & 89 & 324 \\
\hline 1999Q4 & 20 & 171 & 764 & 2008Q1 & 7 & 92 & 285 \\
\hline 2000Q1 & 32 & 226 & 778 & 2008Q2 & 19 & 79 & 265 \\
\hline 2000Q2 & 41 & 162 & 882 & 2008Q3 & 19 & 69 & 277 \\
\hline 2000Q3 & 22 & 128 & 852 & 2008Q4 & 30 & 48 & 237 \\
\hline 2000Q4 & 46 & 202 & 797 & 2009Q1 & 39 & 34 & 204 \\
\hline 2001Q1 & 37 & 208 & 758 & 2009Q2 & 27 & 25 & 223 \\
\hline
\end{tabular}


the average returns on the two high book-to-market portfolios and the two low book-tomarket portfolios. These factors are available on Kenneth French's website in monthly, weekly, and daily frequencies. However, we construct the factors on a quarterly basis to examine quarterly returns.

Finally, we examine the daily returns and excess returns surrounding dividend declarations to detect the effect of dividend changes on returns. Examining quarterly returns is informative, but examining returns surrounding the day of announcement will help us isolate the effect on returns from the dividend change. In order to do this, we calculate the cumulative stock return during days $-1,0$, and +1 , where day 0 is the dividend declaration date. We also calculate the return in excess of the risk free rate, and compare across the types of firms and economic cycles.

\subsection{Empirical Results}

To reiterate our purpose briefly, we are identifying determinants of dividend level changes, and then comparing the returns on dividend paying, non-dividend paying, and switcher firms during the market downturn, which took a major dive in the late summer of 2008, and became very volatile in the months that followed.

Table 13 displays summary statistics on dividend levels, dividend changes, and dividend percent changes for non-dividend payers, regular dividend payers, and switcher firms. Dividend payers tend to payout higher dividends, while non-dividend payers that recently began paying dividends tend to have the highest level of dividend changes, as well as percentage changes.

Table 14 displays the average dividend levels, level changes, and percentage changes throughout our study period. It does not show evidence of major average 
dividend changes or percentage changes during the recession of 2001. On the other hand, the recent recession is marked by average decreases in dividend levels and negative percentage changes, on average, no matter the dividend paying status of the firm. It is also evident that non-dividend paying firms, that recently began paying dividends, seem to experience the most volatility in their dividend payment levels during recessionary periods.

Table 15 provides summary statistics for various determinants of dividend payment identified by previous literature. Summary statistics are divided according to dividend paying status and based on whether the firm increased, decreased, or did not change the dividend payment. On average, dividend payers have higher total assets, market value, profitability, and earned equity. Dividend payers that decrease dividends have lower market value, but their growth opportunities tend to be much higher. In fact, firms that decrease dividend payments have higher growth opportunities regardless of their dividend paying status.

Table 16 also presents summary statistics of various dividend determinants, but they are sorted according to the economic conditions present when the dividend announcement took place. It is notable, that dividend paying firms have the highest total assets and market value, and firms that decrease dividends during a recession have, by far, the highest total assets. On the other hand, the firms that increase dividends during a recession have the highest average market value, even higher than the average market value during an expansion. This implies that increasing dividends during a recession is accepted as a positive signal by the market. 
Table 13

\section{Summary Statistics of Dividend Payment Level, Change, and Percentage Change}

Firms are identified as non-dividend payers if they have not paid a regular cash dividend (distribution code "1232" in the CRSP database) within the last 12 quarters. Firms are identified as dividend payers if they paid a regular cash dividend in the previous 12 quarters. If a firm has paid dividends irregularly within the most recent 12 quarters, it is identified as a "Switcher" firm.

\begin{tabular}{lccrr}
\hline \multicolumn{5}{c}{ Panel 1: Dividend Payment } \\
\hline Status & Mean & Median & Minimum & Maximum \\
\hline Nonpayer & 0.15 & 0.10 & 0.000 & 2.00 \\
Dividend Payer & 0.21 & 0.16 & 0.003 & 5.98 \\
Switcher & 0.17 & 0.11 & 0.002 & 4.45 \\
\hline \multicolumn{5}{c}{} \\
\hline \multicolumn{5}{c}{ Panel 2: Dividend Change } \\
\hline Status & Mean & Median & Minimum & Maximum \\
\hline Nonpayer & 0.003 & 0 & -1.00 & 1.60 \\
Dividend Payer & 0.000 & 0 & -5.30 & 5.30 \\
Switcher & 0.001 & 0 & -2.73 & 5.30 \\
\hline \multicolumn{5}{c}{} \\
\hline Status & Panel 3: Dividend Percent Change & \\
\hline Nonpayer & Mean & Median & Minimum & Maximum \\
Dividend Payer & $10.22 \%$ & $10.22 \%$ & $-99.98 \%$ & $2100 \%$ \\
Switcher & $1.01 \%$ & $1.01 \%$ & $-98.40 \%$ & $6566 \%$ \\
\hline
\end{tabular}


Table 14

\section{Average Dividend Payment Level, Change, and Percentage Change}

Firms are identified as non-dividend payers if they have not paid a regular cash dividend (distribution code "1232" in the CRSP database) within the last 12 quarters. Firms are identified as dividend payers if they paid a regular cash dividend in the previous 12 quarters. If a firm has paid dividends irregularly within the most recent 12 quarters, it is identified as a "Switcher" firm.

\begin{tabular}{|c|c|c|c|c|c|c|c|c|c|}
\hline \multirow[b]{2}{*}{$\begin{array}{l}\text { Year \& } \\
\text { Quarter }\end{array}$} & \multicolumn{3}{|c|}{ NonPayer } & \multicolumn{3}{|c|}{ Payer } & \multicolumn{3}{|c|}{ Switcher } \\
\hline & Payment & Change & $\begin{array}{l}\text { Percent } \\
\text { Change }\end{array}$ & Payment & Change & $\begin{array}{l}\text { Percent } \\
\text { Change }\end{array}$ & Payment & Change & $\begin{array}{l}\text { Percent } \\
\text { Change }\end{array}$ \\
\hline 1993Q1 & 0.104 & 0.019 & $14.85 \%$ & 0.239 & -0.001 & $0.44 \%$ & 0.175 & -0.007 & $0.05 \%$ \\
\hline 1993Q2 & 0.068 & 0.030 & $17.20 \%$ & 0.229 & -0.002 & $0.38 \%$ & 0.123 & -0.001 & $1.30 \%$ \\
\hline 1993Q3 & & & & 0.232 & -0.002 & $-0.11 \%$ & 0.118 & 0.000 & $1.47 \%$ \\
\hline 1993Q4 & 0.136 & 0.025 & $64.66 \%$ & 0.222 & -0.001 & $0.35 \%$ & 0.123 & 0.003 & $3.82 \%$ \\
\hline 1994Q1 & 0.146 & 0.014 & $11.32 \%$ & 0.222 & 0.000 & $1.38 \%$ & 0.128 & 0.007 & $10.01 \%$ \\
\hline 1994Q2 & 0.139 & -0.001 & $3.81 \%$ & 0.220 & -0.001 & $0.66 \%$ & 0.133 & 0.002 & $3.11 \%$ \\
\hline 1994Q3 & 0.138 & 0.002 & $3.54 \%$ & 0.221 & 0.002 & $2.29 \%$ & 0.143 & 0.003 & $5.59 \%$ \\
\hline 1994Q4 & 0.199 & 0.006 & $7.40 \%$ & 0.221 & 0.001 & $1.29 \%$ & 0.150 & 0.004 & $5.22 \%$ \\
\hline 1995Q1 & 0.124 & -0.017 & $-11.90 \%$ & 0.221 & 0.002 & $1.68 \%$ & 0.145 & 0.001 & $2.51 \%$ \\
\hline 1995Q2 & 0.103 & 0.005 & $16.06 \%$ & 0.220 & 0.001 & $1.22 \%$ & 0.151 & 0.004 & $4.48 \%$ \\
\hline 1995Q3 & 0.125 & -0.008 & $-5.12 \%$ & 0.219 & 0.002 & $1.51 \%$ & 0.159 & 0.003 & $5.46 \%$ \\
\hline 1995Q4 & 0.119 & 0.006 & $81.70 \%$ & 0.218 & -0.001 & $1.22 \%$ & 0.155 & 0.002 & $4.60 \%$ \\
\hline 1996Q1 & 0.106 & -0.010 & $6.59 \%$ & 0.218 & 0.001 & $0.80 \%$ & 0.156 & 0.000 & $2.05 \%$ \\
\hline 1996Q2 & 0.128 & 0.004 & $5.54 \%$ & 0.216 & -0.002 & $0.81 \%$ & 0.156 & 0.000 & $2.45 \%$ \\
\hline 1996Q3 & 0.109 & -0.003 & $-4.76 \%$ & 0.214 & -0.001 & $0.42 \%$ & 0.161 & 0.003 & $3.57 \%$ \\
\hline 1996Q4 & 0.098 & -0.016 & $-10.13 \%$ & 0.215 & 0.002 & $1.55 \%$ & 0.152 & 0.004 & $4.84 \%$ \\
\hline 1997Q1 & 0.135 & -0.076 & $-18.41 \%$ & 0.218 & 0.002 & $2.34 \%$ & 0.146 & -0.002 & $1.24 \%$ \\
\hline 1997Q2 & 0.143 & 0.001 & $0.43 \%$ & 0.217 & -0.004 & $0.41 \%$ & 0.148 & 0.002 & $3.43 \%$ \\
\hline 1997Q3 & 0.119 & 0.029 & $26.28 \%$ & 0.212 & -0.003 & $0.00 \%$ & 0.147 & 0.008 & $5.86 \%$ \\
\hline 1997Q4 & 0.160 & 0.041 & $23.82 \%$ & 0.213 & -0.002 & $-0.58 \%$ & 0.153 & -0.001 & $1.64 \%$ \\
\hline 1998Q1 & 0.136 & 0.046 & $144.62 \%$ & 0.212 & -0.001 & $-0.21 \%$ & 0.163 & -0.006 & $-1.02 \%$ \\
\hline 1998Q2 & 0.134 & -0.013 & $-9.34 \%$ & 0.203 & -0.006 & $-1.91 \%$ & 0.163 & -0.003 & $-0.21 \%$ \\
\hline 1998Q3 & 0.138 & 0.005 & $-0.26 \%$ & 0.191 & -0.004 & $-1.23 \%$ & 0.168 & 0.000 & $1.63 \%$ \\
\hline 1998Q4 & 0.140 & -0.009 & $8.50 \%$ & 0.190 & -0.001 & $0.06 \%$ & 0.169 & 0.000 & $1.28 \%$ \\
\hline 1999Q1 & 0.122 & 0.013 & $18.18 \%$ & 0.195 & 0.001 & $0.91 \%$ & 0.172 & 0.000 & $0.75 \%$ \\
\hline 1999Q2 & 0.100 & 0.000 & $4.94 \%$ & 0.188 & 0.000 & $0.95 \%$ & 0.175 & 0.000 & $0.83 \%$ \\
\hline 1999Q3 & 0.065 & -0.001 & $-0.37 \%$ & 0.188 & -0.002 & $-0.82 \%$ & 0.175 & 0.002 & $3.61 \%$ \\
\hline 1999Q4 & 0.191 & 0.009 & $6.79 \%$ & 0.184 & -0.001 & $0.69 \%$ & 0.175 & 0.002 & $4.08 \%$ \\
\hline 2000Q1 & 0.146 & 0.001 & $-1.33 \%$ & 0.184 & 0.002 & $2.02 \%$ & 0.175 & -0.001 & $0.26 \%$ \\
\hline 2000Q2 & 0.109 & 0.130 & $126.67 \%$ & 0.185 & 0.000 & $0.29 \%$ & 0.177 & 0.001 & $1.17 \%$ \\
\hline 2000Q3 & 0.100 & 0.007 & $8.48 \%$ & 0.182 & 0.001 & $0.49 \%$ & 0.181 & 0.000 & $2.76 \%$ \\
\hline 2000Q4 & 0.123 & -0.010 & $-7.19 \%$ & 0.182 & 0.002 & $0.81 \%$ & 0.182 & 0.002 & $3.17 \%$ \\
\hline
\end{tabular}


Table 14 (continued)

\begin{tabular}{|c|c|c|c|c|c|c|c|c|c|}
\hline \multirow[b]{2}{*}{$\begin{array}{l}\text { Year \& } \\
\text { Quarter }\end{array}$} & \multicolumn{3}{|c|}{ NonPayer } & \multicolumn{3}{|c|}{ Payer } & \multicolumn{3}{|c|}{ Switcher } \\
\hline & Payment & Change & $\begin{array}{l}\text { Percent } \\
\text { Change }\end{array}$ & Payment & Change & $\begin{array}{l}\text { Percent } \\
\text { Change }\end{array}$ & Payment & Change & $\begin{array}{l}\text { Percent } \\
\text { Change } \\
\end{array}$ \\
\hline 2001Q1 & 0.075 & 0.000 & $0.00 \%$ & 0.179 & 0.001 & $1.03 \%$ & 0.186 & 0.000 & $0.86 \%$ \\
\hline 2001Q2 & 0.116 & 0.007 & $4.67 \%$ & 0.184 & 0.001 & $0.63 \%$ & 0.181 & 0.000 & $0.69 \%$ \\
\hline 2001Q3 & 0.209 & -0.039 & $4.45 \%$ & 0.181 & -0.001 & $0.38 \%$ & 0.184 & -0.001 & $0.95 \%$ \\
\hline 2001Q4 & 0.187 & -0.003 & $-0.94 \%$ & 0.184 & 0.000 & $1.62 \%$ & 0.177 & 0.000 & $1.31 \%$ \\
\hline 2002Q1 & 0.137 & 0.012 & $42.50 \%$ & 0.185 & 0.000 & $0.40 \%$ & 0.181 & 0.001 & $0.39 \%$ \\
\hline 2002Q2 & 0.120 & 0.000 & $0.00 \%$ & 0.185 & -0.001 & $-0.14 \%$ & 0.185 & 0.002 & $2.47 \%$ \\
\hline 2002Q3 & 0.178 & 0.000 & $2.74 \%$ & 0.185 & 0.000 & $3.82 \%$ & 0.185 & 0.001 & $1.95 \%$ \\
\hline 2002Q4 & 0.087 & -0.011 & $-7.27 \%$ & 0.189 & 0.003 & $1.93 \%$ & 0.184 & 0.006 & $5.87 \%$ \\
\hline 2003Q1 & 0.106 & -0.004 & $101.90 \%$ & 0.191 & 0.000 & $0.78 \%$ & 0.185 & 0.002 & $6.34 \%$ \\
\hline 2003Q2 & 0.114 & 0.028 & $25.65 \%$ & 0.195 & 0.003 & $3.17 \%$ & 0.178 & -0.001 & $2.65 \%$ \\
\hline 2003Q3 & 0.105 & -0.002 & $93.79 \%$ & 0.204 & 0.006 & $4.44 \%$ & 0.164 & 0.004 & $4.99 \%$ \\
\hline 2003Q4 & 0.100 & 0.023 & $58.93 \%$ & 0.205 & -0.001 & $2.24 \%$ & 0.157 & 0.001 & $2.99 \%$ \\
\hline 2004Q1 & 0.085 & 0.023 & $161.52 \%$ & 0.203 & 0.000 & $1.32 \%$ & 0.153 & 0.010 & $10.02 \%$ \\
\hline 2004Q2 & 0.110 & -0.011 & $24.03 \%$ & 0.202 & 0.000 & $1.63 \%$ & 0.150 & 0.007 & $7.24 \%$ \\
\hline 2004Q3 & 0.102 & 0.051 & $92.46 \%$ & 0.205 & 0.002 & $2.08 \%$ & 0.140 & 0.007 & $7.62 \%$ \\
\hline 2004Q4 & 0.105 & -0.004 & $14.76 \%$ & 0.214 & 0.005 & $2.33 \%$ & 0.149 & 0.002 & $5.56 \%$ \\
\hline 2005Q1 & 0.140 & 0.030 & $29.85 \%$ & 0.214 & 0.000 & $1.16 \%$ & 0.154 & 0.003 & $5.10 \%$ \\
\hline 2005Q2 & 0.165 & 0.066 & $50.72 \%$ & 0.214 & -0.001 & $0.96 \%$ & 0.156 & -0.002 & $3.47 \%$ \\
\hline 2005Q3 & 0.097 & -0.001 & $0.72 \%$ & 0.214 & 0.004 & $1.87 \%$ & 0.160 & 0.011 & $11.03 \%$ \\
\hline 2005Q4 & 0.164 & 0.042 & $91.88 \%$ & 0.223 & 0.006 & $3.16 \%$ & 0.167 & 0.005 & $9.74 \%$ \\
\hline 2006Q1 & 0.129 & 0.033 & $46.30 \%$ & 0.222 & 0.001 & $1.24 \%$ & 0.165 & -0.001 & $2.02 \%$ \\
\hline 2006Q2 & 0.116 & 0.018 & $24.22 \%$ & 0.220 & 0.000 & $1.65 \%$ & 0.167 & 0.008 & $6.05 \%$ \\
\hline 2006Q3 & 0.078 & -0.012 & $-7.27 \%$ & 0.218 & 0.002 & $1.64 \%$ & 0.172 & 0.006 & $4.97 \%$ \\
\hline 2006Q4 & 0.177 & 0.058 & $26.34 \%$ & 0.223 & 0.003 & $2.77 \%$ & 0.182 & 0.013 & $10.05 \%$ \\
\hline 2007Q1 & 0.137 & -0.096 & $4.13 \%$ & 0.224 & 0.001 & $1.89 \%$ & 0.184 & 0.008 & $4.07 \%$ \\
\hline 2007Q2 & 0.128 & 0.001 & $5.58 \%$ & 0.225 & 0.004 & $4.63 \%$ & 0.189 & 0.001 & $2.43 \%$ \\
\hline 2007Q3 & 0.167 & -0.011 & $-7.85 \%$ & 0.227 & 0.005 & $2.42 \%$ & 0.196 & 0.013 & $6.63 \%$ \\
\hline 2007Q4 & 0.137 & -0.007 & $6.08 \%$ & 0.236 & -0.002 & $2.71 \%$ & 0.208 & -0.001 & $23.28 \%$ \\
\hline 2008Q1 & 0.138 & 0.051 & $123.91 \%$ & 0.231 & 0.000 & $0.01 \%$ & 0.205 & 0.000 & $1.10 \%$ \\
\hline 2008Q2 & 0.102 & -0.003 & $43.06 \%$ & 0.232 & 0.000 & $0.88 \%$ & 0.199 & -0.015 & $-0.61 \%$ \\
\hline 2008Q3 & 0.184 & 0.178 & $46.66 \%$ & 0.232 & -0.006 & $-1.85 \%$ & 0.192 & -0.011 & $-3.35 \%$ \\
\hline 2008Q4 & 0.440 & 0.216 & $341.67 \%$ & 0.221 & -0.022 & $-7.15 \%$ & 0.171 & -0.012 & $-3.41 \%$ \\
\hline 2009Q1 & 0.050 & -0.127 & $-22.07 \%$ & 0.208 & -0.015 & $-5.46 \%$ & 0.160 & 0.000 & $2.46 \%$ \\
\hline 2009Q2 & 0.234 & -0.071 & $-36.41 \%$ & 0.204 & -0.002 & $-1.03 \%$ & 0.169 & 0.005 & $3.23 \%$ \\
\hline
\end{tabular}


In order to determine the factors affecting dividend changes, we employ a polytomous logistic regression. A polytomous logistic regression allows for a dependent variable that has more than two categorical responses. Therefore, our response row is

$$
y_{i}=\left(y_{i 1}, y_{i 2}, \ldots, y_{i r}\right)^{T}
$$

We assume a multinomial distribution with index $n_{i}=\sum_{j=1}^{r} y_{i j}$ and parameter $\pi_{i}=\left(\pi_{i 1}, \pi_{i 2}, \ldots, \pi_{i r}\right)^{T}$. We relate $\pi_{i}$ to covariates through a set of r-1 baseline-category logits. Taking $\mathrm{j}^{*}$ as the baseline category, the model is

$$
\log \left(\frac{\pi_{i j}}{\pi_{i j^{*}}}\right)=x_{i}^{T} \beta_{j}, \quad j \neq j^{*} .
$$

If $\mathrm{x}_{\mathrm{i}}$ has length $\mathrm{p}$, then the model has $(r-1) \times p$ free parameters, which we can arrange as a matrix or a vector. The last category is the baseline $\left(j^{*}=r\right)$, so the coefficients are

$$
\beta=\left[\beta_{1}, \beta_{2}, \ldots, \beta_{r-1}\right]
$$

Or

$$
\operatorname{vec}(\beta)=\left[\begin{array}{c}
\beta_{1} \\
\beta_{2} \\
\vdots \\
\beta_{r-1}
\end{array}\right]
$$

The kth element of $\beta_{j}$ can be interpreted as: the increase in log-odds of falling into category $\mathrm{j}$ versus category $\mathrm{j}^{*}$ resulting from a one-unit increase in the kth covariate, holding the other covariates constant.

Table 17 displays results of a polytomous logistic regression where the response variable is

$$
Y_{i}=\left\{\begin{array}{l}
1 \text { if the dividend increases } \\
2 \text { if the dividend decreases } \\
3 \text { if the dividend remains unchanged }
\end{array}\right.
$$




\section{Table 15}

\section{Summary Statistics of Dividend Determinants According to Dividend Paying Status}

The Total Assets are reported in millions of US dollars and are equal to the book value of total assets. Growth Opportunities 1 is calculated as the ratio of the market value of total capital to the book value of total assets ((book value of total assets-book value of equity + market value of equity)/book value of total assets). Growth Opportunities 2 is calculated as the percent change in assets over the quarter. Earned Equity is calculated as ratio of retained earnings to the book value of equity. Profitability 1 is calculated as the ratio of earnings before interest to the book value of total assets. Profitability 2 is calculated as the ratio of after-tax earnings to the book value of equity. Firms are identified as non-dividend payers if they have not paid a regular cash dividend (distribution code "1232" in the CRSP database) within the last 12 quarters. Firms are identified as dividend payers if they paid a regular cash dividend in the previous 12 quarters. If a firm has paid dividends irregularly within the most recent 12 quarters, it is identified as a "Switcher" firm.

\begin{tabular}{|c|c|c|c|c|c|c|c|c|c|}
\hline & \multicolumn{3}{|c|}{ Nonpayer } & \multicolumn{3}{|c|}{ Payer } & \multicolumn{3}{|c|}{ Switcher } \\
\hline & Decrease & Increase & NoChange & Decrease & Increase & NoChange & Decrease & Increase & NoChange \\
\hline Total Assets & $4,405.60$ & $6,808.85$ & $7,065.50$ & $16,115.15$ & $13,237.46$ & $11,148.12$ & $9,085.64$ & $8,055.03$ & $5,809.01$ \\
\hline Market Value & $1,796.23$ & $3,588.59$ & $3,211.76$ & $4,799.14$ & $6,401.24$ & $5,142.08$ & $4,128.56$ & $3,589.07$ & $3,069.75$ \\
\hline Profitability 1 & 0.016 & 0.014 & 0.010 & 0.043 & 0.025 & 0.010 & 0.026 & 0.016 & 0.010 \\
\hline Profitability 2 & 0.041 & 0.043 & 0.064 & 1.069 & 0.323 & 0.042 & 3.491 & 0.182 & 0.031 \\
\hline Earned Equity & 0.353 & 0.314 & 0.379 & 0.534 & 0.643 & 0.786 & 0.187 & 0.447 & 0.437 \\
\hline Growth Opportunities 1 & 1.124 & 0.799 & 0.725 & 2.443 & 1.322 & 0.820 & 1.582 & 0.889 & 0.773 \\
\hline Growth Opportunities 2 & -19.420 & -6.760 & -1.389 & -14.505 & -3.214 & -1.680 & -9.867 & -1.221 & -0.269 \\
\hline
\end{tabular}




\section{Table 16}

\section{Summary Statistics of Dividend Determinants According to Dividend Paying Status and Economic Cycle}

The Total Assets are reported in millions of US dollars and are equal to the book value of total assets. Growth Opportunities 1 is calculated as the ratio of the market value of total capital to the book value of total assets ((book value of total assets-book value of equity + market value of equity)/book value of total assets). Growth Opportunities 2 is calculated as the percent change in assets over the quarter. Earned Equity is calculated as ratio of retained earnings to the book value of equity. Profitability 1 is calculated as the ratio of earnings before interest to the book value of total assets. Profitability 2 is calculated as the ratio of after-tax earnings to the book value of equity. Firms are identified as non-dividend payers if they have not paid a regular cash dividend (distribution code "1232" in the CRSP database) within the last 12 quarters. Firms are identified as dividend payers if they paid a regular cash dividend in the previous 12 quarters. If a firm has paid dividends irregularly within the most recent 12 quarters, it is identified as a "Switcher" firm. A quarter is labeled as expansion or recession if it is classified as such by the National Bureau of Economic Research. According to the NBER recessions occurred between March 2001 and November 2001 and between December 2007 and June 2009.

\begin{tabular}{|c|c|c|c|c|c|c|}
\hline & \multicolumn{3}{|c|}{ Expansion } & \multicolumn{3}{|c|}{ Recession } \\
\hline & Decrease & Increase & No Change & Decrease & Increase & No Change \\
\hline \multicolumn{7}{|c|}{ Nonpayer } \\
\hline Total Assets & $4,496.70$ & $4,255.23$ & $7,043.33$ & $3,130.30$ & $78,982.07$ & $8,329.52$ \\
\hline Market Value & $1,752.57$ & $3,111.91$ & $3,163.78$ & $2,407.42$ & $17,061.22$ & $5,948.07$ \\
\hline Profitability 1 & 0.01 & 0.01 & 0.01 & 0.04 & 0.04 & 0.01 \\
\hline Profitability 2 & 0.04 & 0.03 & 0.06 & 0.08 & 0.30 & 0.03 \\
\hline Earned Equity & 0.38 & 0.31 & 0.38 & -0.03 & 0.37 & 0.53 \\
\hline Growth Opportunities 1 & 1.10 & 0.78 & 0.73 & 1.40 & 1.45 & 0.60 \\
\hline Growth Opportunities 2 & -20.79 & -4.88 & -1.41 & -0.25 & -59.89 & -0.01 \\
\hline \multicolumn{7}{|c|}{ Payer } \\
\hline Total Assets & $7,904.54$ & $12,900.51$ & $10,364.01$ & $45,971.93$ & $15,691.21$ & $15,706.58$ \\
\hline Market Value & $5,034.00$ & $6,049.81$ & $4,963.28$ & $3,945.10$ & $8,960.50$ & $6,181.54$ \\
\hline Profitability 1 & 0.04 & 0.02 & 0.01 & 0.07 & 0.05 & 0.01 \\
\hline Profitability 2 & 1.30 & 0.27 & 0.05 & 0.24 & 0.68 & -0.04 \\
\hline Earned Equity & 0.58 & 0.64 & 0.64 & 0.38 & 0.69 & 1.59 \\
\hline Growth Opportunities 1 & 2.21 & 1.24 & 0.84 & 3.29 & 1.92 & 0.73 \\
\hline Growth Opportunities 2 & -6.12 & -2.75 & -1.66 & -45.00 & -6.59 & -1.82 \\
\hline \multicolumn{7}{|c|}{ Switcher } \\
\hline Total Assets & $6,949.95$ & $7,490.64$ & $5,423.61$ & $21,454.82$ & $12,261.51$ & $8,478.20$ \\
\hline Market Value & $4,132.21$ & $3,369.97$ & $2,857.71$ & $4,107.45$ & $5,222.01$ & $4,538.30$ \\
\hline Profitability 1 & 0.03 & 0.02 & 0.01 & 0.03 & 0.02 & 0.01 \\
\hline Profitability 2 & 0.48 & 0.12 & 0.03 & 20.95 & 0.67 & 0.02 \\
\hline Earned Equity & 0.43 & 0.45 & 0.44 & -1.31 & 0.40 & 0.42 \\
\hline Growth Opportunities 1 & 1.60 & 0.89 & 0.79 & 1.46 & 0.85 & 0.69 \\
\hline Growth Opportunities 2 & -10.56 & -1.28 & -0.29 & -5.87 & -0.76 & -0.11 \\
\hline
\end{tabular}


The predictors of interest include the firm's dividend paying status, as described above, the state of the economy, the firm's total assets, growth opportunities, earned equity, and profitability.

The results of Panel 2 in Table 17 show that dividend paying status, economic conditions, and total assets have a discernable effect on dividend changes at the $0.01 \%$ level, and profitability has discernable effects on dividend changes at the $10 \%$ level. Growth opportunities and earned equity have no discernable effect on dividend changes.

The parameter estimates are displayed in Panel 3. The intercepts give the estimated log-odds for the reference group Status $=$ Switcher. The estimated log-odds of a decrease versus not changing the dividend level is -4.60 , and the estimated log-odds of an increase versus not changing the dividend level is -3.5. Therefore, switchers are less likely to change the dividend level. Just as the Type III analysis implies, earned equity is not significant in determining a dividend increase, decrease, or no change. However, a one unit increase in growth opportunities is significantly related to a decrease in dividend levels.

Although the logistic regression results find a significant difference between dividend paying status, in terms of the change in dividend level, the difference between nonpayers and switcher is economically insignificant. On the other hand, dividend payers show more volatility in changing dividend levels. A dividend payer is $1.51 \%$ more likely than a switcher to decrease a dividend and $1.067 \%$ more likely to increase a dividend. The economy also plays a role in changes in the dividend level. In an expansion, a firm is $0.74 \%$ less likely to decrease a dividend and $1.38 \%$ more likely to increase a dividend, versus leaving the dividend level unchanged. An increase in total assets leads to volatility 
in dividend changes. A one unit increase in total assets, implies that firms are $1 \%$ more likely to both decrease or increase the dividend level, as opposed to not changing the dividend. As pointed out in previous literature, and implied by various results in this dissertation, an increase in growth opportunities implies a $1 \%$ increase in the likelihood that a firm will decrease a dividend, while a one unit increase in profitability implies a $1.01 \%$ increase in the likelihood that a firm will increase the dividend level.

The results provided above as well as those in chapter 1 of this dissertation, imply that dividend characteristics of firms are significantly different across dividend paying status and economic cycles. We now investigate differences in returns between regular dividend payers, non-dividend payers and switcher firms using the Fama and French three factor model.

The Fama and French factors, SMB and HML, are formed on a monthly basis. Because we employ quarterly, rather than monthly returns, we form the factors on a quarterly basis using the Fama and French (1993) procedure.

In order to sort the stocks according to dividend paying classification, we use the distribution code "1232" in the CRSP database. The description for this distribution code in the CRSP Data Description Guide is: U.S. cash dividend, quarterly, taxable same rate as dividend. We sort the stocks in 3 different categories as described previously: Regular Dividend Payer, Nonpayer, and Switcher.

Table 18 displays summary statistics for the average excess return, market value, and book-to-market ratio. The results show average excess return to be highest for nondividend paying firms, which drives up the average for the sample including all types of 


\section{Table 17}

\section{Generalized Logarithmic Regression With Growth Opportunities 1 and Profitability 1 and NBER Market Measure}

The probability modeled is that Change $=$ 'No Change'. Using a polytomous logit model, variables are selected using forward selection process. The Status effect is represented by the two binary variables: Nonpayer and Payer. The binary variable "Nonpayer" is equal to 1 if the firm has not paid a regular cash dividend (distribution code "1232" in the CRSP database) within the previous 12 quarters, and it is equal to 0 otherwise. The binary variable "Payer" is equal to 1 if the firm has paid a regular cash dividend (distribution code "1232" in the CRSP database) in all of the previous 12 quarters, and it is equal to 0 otherwise. We measure the effect of the market according to the expansion and contractions defined by the NBER. The Economic Cycle effect is introduced as a binary variable called Expansion that is equal to 1 if the market is in an expansionary quarter and 0 when the market is in a contraction or recession period. Total Assets is the book value of total assets in the prior quarter. Growth Opportunities 1 is calculated as the ratio of the market value of total capital to the book value of total assets ((book value of total assetsbook value of equity + market value of equity)/book value of total assets) in the prior quarter. Profitability 1 is calculated as the ratio of earnings before interest to the book value of total assets in the prior quarter.

\begin{tabular}{|c|c|c|c|c|}
\hline \multicolumn{4}{|c|}{ Panel 1: Fit Statistics } & \\
\hline Criterion & $\begin{array}{l}\text { Intercept I } \\
\text { Only }\end{array}$ & \multicolumn{2}{|c|}{$\begin{array}{l}\text { Intercept And } \\
\text { Covariates }\end{array}$} & \\
\hline AIC & 207,509 & \multicolumn{2}{|c|}{149,422} & \\
\hline $\mathrm{SC}$ & 207,531 & \multicolumn{2}{|c|}{149,600} & \\
\hline$-2 \log L$ & 207,505 & \multicolumn{2}{|c|}{149,390} & \\
\hline \multicolumn{5}{|c|}{ Panel 2: Analysis of Effects } \\
\hline \multicolumn{2}{|l|}{ Effect } & DF & $\begin{array}{l}\text { Wald } \\
\text { ChiSq }\end{array}$ & $\begin{array}{l}\text { Prob } \\
\text { ChiSq }\end{array}$ \\
\hline \multicolumn{2}{|l|}{ Status } & 4 & $15,154.93$ & $<.0001$ \\
\hline \multicolumn{2}{|c|}{ Economic Cycle } & 2 & 231.58 & $<.0001$ \\
\hline \multicolumn{2}{|c|}{ Total Assets } & 2 & 45.15 & $<.0001$ \\
\hline \multicolumn{2}{|c|}{ Growth Opportunities 1} & 2 & 3.83 & 0.147 \\
\hline \multicolumn{2}{|c|}{ Earned Equity } & 2 & 1.01 & 0.605 \\
\hline \multicolumn{2}{|c|}{ Profitability 1} & 2 & 5.45 & 0.066 \\
\hline
\end{tabular}


Table 17 (continued)

\begin{tabular}{|c|c|c|c|c|c|c|c|}
\hline \multicolumn{8}{|c|}{ Panel 3: Parameter Estimates } \\
\hline Variable & ClassVal0 & Response & DF & Estimate & StdErr & $\begin{array}{l}\text { Wald } \\
\text { ChiSq }\end{array}$ & $\begin{array}{l}\text { Prob } \\
\text { ChiSq }\end{array}$ \\
\hline Intercept & & Decrease & 1 & -4.601 & 0.029 & $24,571.74$ & $<.0001$ \\
\hline Intercept & & Increase & 1 & -3.501 & 0.019 & $35,904.48$ & $<.0001$ \\
\hline Status & Nonpayer & Decrease & 1 & -2.870 & 0.049 & $3,427.29$ & $<.0001$ \\
\hline Status & Nonpayer & Increase & 1 & -3.197 & 0.030 & $11,676.20$ & $<.0001$ \\
\hline Status & Payer & Decrease & 1 & 1.506 & 0.029 & $2,730.20$ & $<.0001$ \\
\hline Status & Payer & Increase & 1 & 1.631 & 0.017 & $9,535.32$ & $<.0001$ \\
\hline Economic Cycle & Expansion & Decrease & 1 & -0.151 & 0.020 & 55.61 & $<.0001$ \\
\hline Economic Cycle & Expansion & Increase & 1 & 0.161 & 0.013 & 161.32 & $<.0001$ \\
\hline Total Assets & & Decrease & 1 & 0.000 & 0.000 & 23.66 & $<.0001$ \\
\hline Total Assets & & Increase & 1 & 0.000 & 0.000 & 29.41 & $<.0001$ \\
\hline Growth Opportunities 1 & & Decrease & 1 & 0.000 & 0.000 & 3.39 & 0.066 \\
\hline Growth Opportunities 1 & & Increase & 1 & 0.000 & 0.000 & 0.54 & 0.464 \\
\hline Earned Equity & & Decr & 1 & 0.000 & 0.000 & 0.32 & 0.571 \\
\hline Earned Equity & & Increase & 1 & 0.000 & 0.000 & 0.68 & 0.411 \\
\hline Profitability 1 & & Decrease & 1 & 0.011 & 0.007 & 2.35 & 0.125 \\
\hline Profitability 1 & & Increase & 1 & 0.010 & 0.005 & 3.94 & 0.047 \\
\hline
\end{tabular}

\begin{tabular}{lllrrr}
\hline \multicolumn{2}{c}{ Panel 4: Odds Ratio Estimates } & & & & \\
\hline Effect & & Response & OddsRatioEst & LowerCL & UpperCL \\
\hline Status & Nonpayer vs Switcher & Decrease & 0.014 & 0.012 & 0.017 \\
Status & Nonpayer vs Switcher & Increase & 0.009 & 0.008 & 0.009 \\
Status & Payer vs Switcher & Decrease & 1.151 & 1.08 & 1.228 \\
Status & Payer vs Switcher & Increase & 1.067 & 1.033 & 1.101 \\
EconomicCycle & Expansion vs & & & & \\
Recession & & Decrease & 0.74 & 0.683 & 0.801 \\
EconomicCycle & Expansion vs & & & & \\
Recession & Increase & 1.38 & 1.313 & 1.45 \\
LTotalAssets & Decrease & 1 & 1 & 1 \\
LTotalAssets & Increase & 1 & 1 & 1 \\
LGrowthOpportunities & Decrease & 1 & 1 & 1.001 \\
LGrowthOpportunities & Increase & 1 & 1 & 1.001 \\
LEarnedEquity & Decrease & 1 & 1 & 1.001 \\
LEarnedEquity & Increase & 1 & 1 & 1 \\
LProfitability1 & Decrease & 1.011 & 0.997 & 1.025 \\
LProfitability1 & Increase & 1.01 & 1 & 1.021 \\
\hline
\end{tabular}


firms. Firms that regularly pay dividends and firms that initiate dividends earn the lowest excess returns.

Market value of the regular dividend paying group is far greater than the market value of all other groups. It is followed by the switcher group. This implies that large size is associated with dividend payments, as has been noted in previous literature.

Variation in excess returns for non-dividend payers is very high, relative to its mean and to the standard deviation of other groups. It is also driving up the standard deviation of the sample that includes all firms. Average book-to-market ratio for nondividend payers is also much higher than for other groups, which seems to be driving up the average book-to-market ratio for the total sample. This implies that "value" stocks are concentrated in the nonpayer group, while the other groups consist of "growth" stocks.

Table 19 displays the average excess return, market value, and book-to-market ratio as in Table 18, but divides the statistics by economic cycle, as classified by the NBER. According to the NBER, economic contractions in the United States include the time period between March 2001 and November 2001, as well as the period between December 2007 and June 2009.

The results show that average excess return was highest for the non-dividend paying group in both the expansions and recessions. Average excess returns actually decrease for all groups except nonpayers. In fact, the average book-to-market ratio increased for all firms except nonpayers. In a market downturn, we would assume this implies a decrease in market value, but the data shows an increase in average market value. This implies that book value must have increased. An increase in book value can arise from an increase in assets or a decrease in liabilities. Increases in book value are 
Table 18

\title{
Summary Statistics: Excess Return, Market Value and Book-to-Market Ratio by Dividend-Paying Status (1990 - 2009)
}

\begin{abstract}
Excess return is calculated as the difference between the firms quarterly return and the three-month T-bill rate. Market value is calculated as the product of the number of shares outstanding and the close price at the end of the quarter. Book-to-market ratio is calculated as the ratio of Book Equity to Market Value at the end of the quarter. Book Equity is the sum of common equity and deferred taxes on the balance sheet at the end of the quarter. During the period between 1993 and 2009 the number of regular dividend payers ranged from a minimum of 427 in the fourth quarter of 2000 to a maximum of 1,428 in the first quarter of 1997. During the same time period, the number of switchers ranged from a minimum of 275 in second quarter of 2009 to maximum of 1,103 in the second quarter of 1999 . Non-dividend payers ranged from 3,103 in the second quarter of 2009 to 5,226 in the first quarter of 1997.
\end{abstract}

\begin{tabular}{ccccc}
\hline Sample & $\begin{array}{c}\text { Avg Excess } \\
\text { Return }\end{array}$ & $\begin{array}{c}\text { StdDev Excess } \\
\text { Return }\end{array}$ & $\begin{array}{c}\text { Avg Market } \\
\text { Value }\end{array}$ & $\begin{array}{c}\text { Avg Book-to-Market } \\
\text { Ratio }\end{array}$ \\
\hline All & 0.13 & 22.26 & 1813 & 4.89 \\
Regular & 0.01 & 0.16 & 11470 & 0.56 \\
Switcher & 0.02 & 0.39 & 3778 & 0.75 \\
Nonpayer & 0.19 & 27.49 & 900 & 8.32 \\
\hline
\end{tabular}

usually related to increases in earnings. This is surprising considering the market downturn.

Table 20 shows regression results for the Fama-French three-factor model regressions by type of dividend payer. Although nonpayers had higher excess returns, as show in Tables 18 and 19, regular dividend payers have significantly higher abnormal returns than other types of firms. Although not significant, the abnormal return for nonpayers is -0.005 , while regular payers have an abnormal return of 0.007 at the $1 \%$ level. Switchers also experience significantly higher abnormal returns of 0.009 at the $10 \%$ level. The R-square for switcher firms may be low due to the type of firms in those groups and the number of observations in each group. Although the market factor is significant for the switcher firms, the size and book-to-market ratio factors are not. It may be that the switcher firms, may be midsize or larger firms that do not have returns related 
Table 19

Summary Statistics: Excess Return, Market Value and Book-to-Market Ratio by Dividend-Paying Status and Time (1990 - 2009)

Excess return is calculated as the difference between the firms quarterly return and the three-month T-bill rate. Market value is calculated as the product of the number of shares outstanding and the close price at the end of the quarter. Book-to-market ratio is calculated as the ratio of Book Equity to Market Value at the end of the quarter. Book Equity is the sum of common equity and deferred taxes on the balance sheet at the end of the quarter. During the period between 1993 and 2009 the number of regular dividend payers ranged from a minimum of 427 in the fourth quarter of 2000 to a maximum of 1,428 in the first quarter of 1997. During the same time period, the number of switchers ranged from a minimum of 275 in second quarter of 2009 to maximum of 1,103 in the second quarter of 1999 . Non-dividend payers ranged from 3,103 in the second quarter of 2009 to 5,226 in the first quarter of 1997. We divide the samples into two time periods to distinguish between recession and non-recession periods. According to the NBER, the US experienced economic contractions in the periods March 2001 - November 2001 and December 2007 - June 2009.

\begin{tabular}{|c|c|c|c|c|}
\hline Economic Cycle & $\begin{array}{l}\text { Avg Excess } \\
\text { Return }\end{array}$ & $\begin{array}{l}\text { StdDev Excess } \\
\text { Return }\end{array}$ & $\begin{array}{l}\text { Avg Market } \\
\text { Value }\end{array}$ & $\begin{array}{c}\text { Avg Book-to-Market } \\
\text { Ratio }\end{array}$ \\
\hline \multicolumn{5}{|c|}{ All } \\
\hline Expansion & 0.141 & 23.396 & 1718 & 5.879 \\
\hline Recession & 0.063 & 2.280 & 2675 & 6.188 \\
\hline \multicolumn{5}{|c|}{ Regular } \\
\hline Expansion & 0.005 & 0.153 & 10996 & 0.542 \\
\hline Recession & 0.001 & 0.226 & 15370 & 0.669 \\
\hline \multicolumn{5}{|c|}{ Switcher } \\
\hline Expansion & 0.017 & 0.394 & 3563 & 0.723 \\
\hline Recession & -0.003 & 0.391 & 6173 & 1.011 \\
\hline \multicolumn{5}{|c|}{ Nonpayer } \\
\hline Expansion & 0.204 & 28.874 & 851 & 8.524 \\
\hline Recession & 0.339 & 19.661 & 1412 & 6.557 \\
\hline
\end{tabular}

to small size. They may also not have high book-to-market ratios, as seen in Table 18 .

Once we divide the samples according to economic cycle, in Table 21, abnormal

return no longer seems significant. However, it is interesting that during recessions,

regular dividend payers have a positive abnormal return of 0.006 at the $5 \%$ level.

Although the results show an abnormal return of 0.402 for non-dividend payers, it is not significantly different from zero.

The Fama-French factors do not seem to be significant for other groups, except

the regular dividend payers. 
Table 20

Fama-French Three Factor Regressions by Dividend-Paying Status (1990-2009)

Quarterly returns are calculated for every NYSE, AMEX, and Nasdaq firms. They are then sorted by size and book-tomarket to form six portfolios to generate the factors SMB and HML. Size is the market value for each firm at the end of the quarter and $\mathrm{BE} / \mathrm{ME}$ is the ratio of book equity to market equity, where $\mathrm{BE}$ is calculated from the Compustat database as in Fama and French (1993). Regression results for the Fama-French three-factor model $R_{i}=a_{i}+b_{i}\left(R_{m}-R_{f}\right)$ $+\mathrm{s}_{\mathrm{i}} \mathrm{SMB}+\mathrm{h}_{\mathrm{i}} \mathrm{HML}+\mathrm{e}_{\mathrm{i}}$ are shown below. During the period between 1993 and 2009 the number of regular dividend payers ranged from a minimum of 427 in the fourth quarter of 2000 to a maximum of 1,428 in the first quarter of 1997. During the same time period, the number of switchers ranged from a minimum of 275 in second quarter of 2009 to maximum of 1,103 in the second quarter of 1999. Non-dividend payers ranged from 3,103 in the second quarter of 2009 to 5,226 in the first quarter of 1997.

\begin{tabular}{|c|c|c|c|c|c|c|c|c|c|}
\hline \multirow[b]{2}{*}{ Sample } & \multicolumn{4}{|c|}{ Estimated Parameter Values } & \multicolumn{4}{|c|}{ T-Values } & \multirow[b]{2}{*}{$\mathrm{R}-\mathrm{Sq}$} \\
\hline & $\mathrm{a}$ & $\mathrm{b}$ & $\mathrm{s}$ & $\mathrm{h}$ & $\mathrm{a}$ & $\mathrm{b}$ & $\mathrm{s}$ & $\mathrm{h}$ & \\
\hline All & 0.049 & 0.747 & 0.381 & -0.189 & 1.665 & 2.663 & 2.823 & -2.071 & 25.73 \\
\hline Regular & 0.007 & 0.616 & -0.093 & 0.064 & 2.520 & 22.677 & -7.636 & 7.937 & 22.91 \\
\hline Swit & 0.009 & 0.600 & 0.011 & 0.007 & 1.676 & 11.053 & 0.496 & 0.484 & 7.37 \\
\hline Nonpayer & -0.005 & 1.287 & 0.732 & -0.084 & -0.182 & 4.955 & 6.316 & -1.095 & 78.40 \\
\hline
\end{tabular}

There is a concern with the data. There were only a few quarters that the NBER classified as economic contractions. On the other hand, we have many observations during economic expansions. Regression results for the recession periods may be affected by the limited number of periods classified as contractions. However, there are a large number of firms in each group. Of course, the non-dividend payers have a much higher number of observations in each quarter. Therefore, the data for nonpayer is more approximate to normal.

Table 22 provides descriptive statistics regarding the dividend changes and daily returns associated those changes. Panel 1 of Table 22 provides descriptive statistics for the rate of change in the dividend levels, the average returns, and excess returns. The largest dividend decreases seem to come from Switcher firms. The largest dividend increases can also be attributed to Switcher firms. It may be that firms do not have a history of paying dividends regularly, and only pay in instances when it benefits the firm. For example, Switcher firms may pay dividends when the firm has excess cash flow or 
Table 21

Fama-French Three Factor Regressions by Dividend-Paying Status and Time (19902009)

Quarterly returns are calculated for every NYSE, AMEX, and Nasdaq firms. They are then sorted by size and book-tomarket to form six portfolios to generate the factors SMB and HML. Size is the market value for each firm at the end of the quarter and $\mathrm{BE} / \mathrm{ME}$ is the ratio of book equity to market equity, where BE is calculated from the Compustat database as in Fama and French (1993). Regression results for the Fama-French three-factor model $R_{i}=a_{i}+b_{i}\left(R_{m}-R_{f}\right)$ $+\mathrm{s}_{\mathrm{i}} \mathrm{SMB}+\mathrm{h}_{\mathrm{i}} \mathrm{HML}+\mathrm{e}_{\mathrm{i}}$ are shown below. During the period between 1993 and 2009 the number of regular dividend payers ranged from a minimum of 427 in the fourth quarter of 2000 to a maximum of 1,428 in the first quarter of 1997. During the same time period, the number of switchers ranged from a minimum of 275 in second quarter of 2009 to maximum of 1,103 in the second quarter of 1999. Non-dividend payers ranged from 3,103 in the second quarter of 2009 to 5,226 in the first quarter of 1997 . We divide the samples into two time periods to distinguish between recession and non-recession periods. According to the NBER, the US experienced economic contractions in the periods March 2001 - November 2001 and December 2007 - June 2009.

\begin{tabular}{|c|c|c|c|c|c|c|c|c|c|}
\hline \multirow[b]{2}{*}{ Sample } & \multicolumn{4}{|c|}{ Estimated Parameter Values } & \multicolumn{4}{|c|}{ T-Values } & \multirow[b]{2}{*}{$\mathrm{R}-\mathrm{Sq}$} \\
\hline & $\mathrm{a}$ & $\mathrm{b}$ & $\mathrm{s}$ & $\mathrm{h}$ & $\mathrm{a}$ & $\mathrm{b}$ & $\mathrm{s}$ & $\mathrm{h}$ & \\
\hline \multicolumn{10}{|c|}{ All } \\
\hline Expansion & -0.009 & 1.029 & 0.506 & -0.058 & -0.442 & 4.622 & 5.798 & -0.995 & 77.98 \\
\hline Recession & 0.086 & 1.573 & 0.112 & -0.015 & 1.287 & 4.778 & 0.249 & -0.032 & 92.39 \\
\hline \multicolumn{10}{|c|}{ Regular } \\
\hline Expansion & -0.006 & 0.841 & -0.080 & 0.437 & -0.360 & 10.561 & -0.738 & 3.862 & 65.02 \\
\hline Recession & 0.006 & 0.497 & -0.074 & 0.051 & 1.986 & 16.308 & -6.192 & 6.466 & 14.88 \\
\hline \multicolumn{10}{|c|}{ Switcher } \\
\hline Expansion & 0.011 & 0.597 & -0.025 & 0.021 & 1.406 & 7.291 & -0.791 & 0.970 & 44.64 \\
\hline Recession & -0.014 & 1.016 & 0.076 & 0.524 & -0.313 & 4.643 & 0.255 & 1.685 & 94.52 \\
\hline \multicolumn{10}{|c|}{ Nonpayer } \\
\hline Expansion & -0.016 & 1.218 & 0.763 & -0.103 & -0.516 & 3.853 & 6.155 & -1.253 & 78.32 \\
\hline Recession & 0.402 & 0.477 & -0.582 & 1.305 & 1.022 & 0.245 & -0.218 & 0.471 & 0.51 \\
\hline
\end{tabular}

when firm managers see the need to signal to investors (Fuller and Blau, 2010). In

examining the average returns on day -1 , day 0 , and day 1 (day 0 is the declaration day),

we can see that the average return is higher surrounding a dividend increase, and lower

(even negative in some cases) surrounding a dividend decrease. The same can be said

when examining excess return.

Panels 2 and 3 are similar to Panel 1, but Panel 2 examines economic expansions, while Panel 3 examines economic recessions. In Panel 2, average returns are lowest 
surrounding a dividend decrease, but for the most part, remain positive. On the other hand, average returns and excess returns are all negative surrounding a dividend decrease in Panel 3. Comparing returns surrounding dividend increases across Panels 1 through 3, we can see that returns are much higher in Panel 3. Returns and excess returns are also higher during the recessions for firms that did not change their dividend. It may be that investors saw steady dividend levels as positive signs and dividend increases, as extremely positive signals.

The results in Panel 2, during expansions, imply that investors are not too concerned with dividend decreases during expansions. When economic conditions are promising, negative information such as dividend decreases may not be highlighted in the financial news, and therefore, it may be dismissed by investors. On the other hand, economic contractions increase uncertainty and volatility. Any information, such as dividend announcements, is followed by large reactions in returns. This supports they study by Lee (1995) that finds investor overreaction to temporary dividend changes. Because investors cannot distinguish between permanent or temporary changes, they react strongly especially in times of uncertainty. 
Table 22

Descriptive Statistics for Dividend Changes and Associated Returns

$\mathrm{R} \Delta \mathrm{Div}$ is the rate of change in quarterly dividend per share. $\mathrm{R}$ is cumulative stock return during days $-1,0$, and 1 relative to the dividend declaration. ER is $\mathrm{R}$ minus contemporaneous return on the CRSP index.

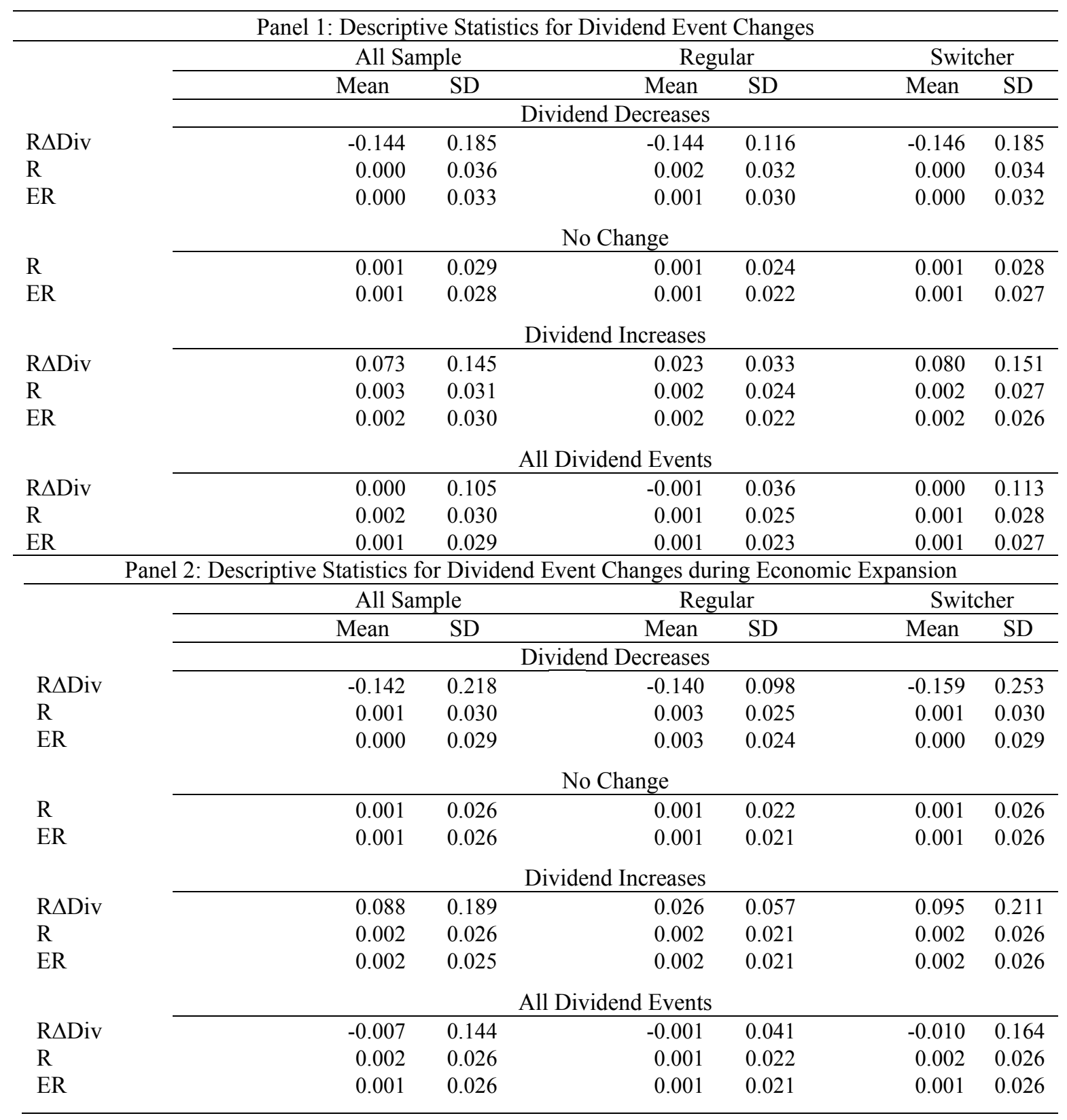


Table 22 (continued)

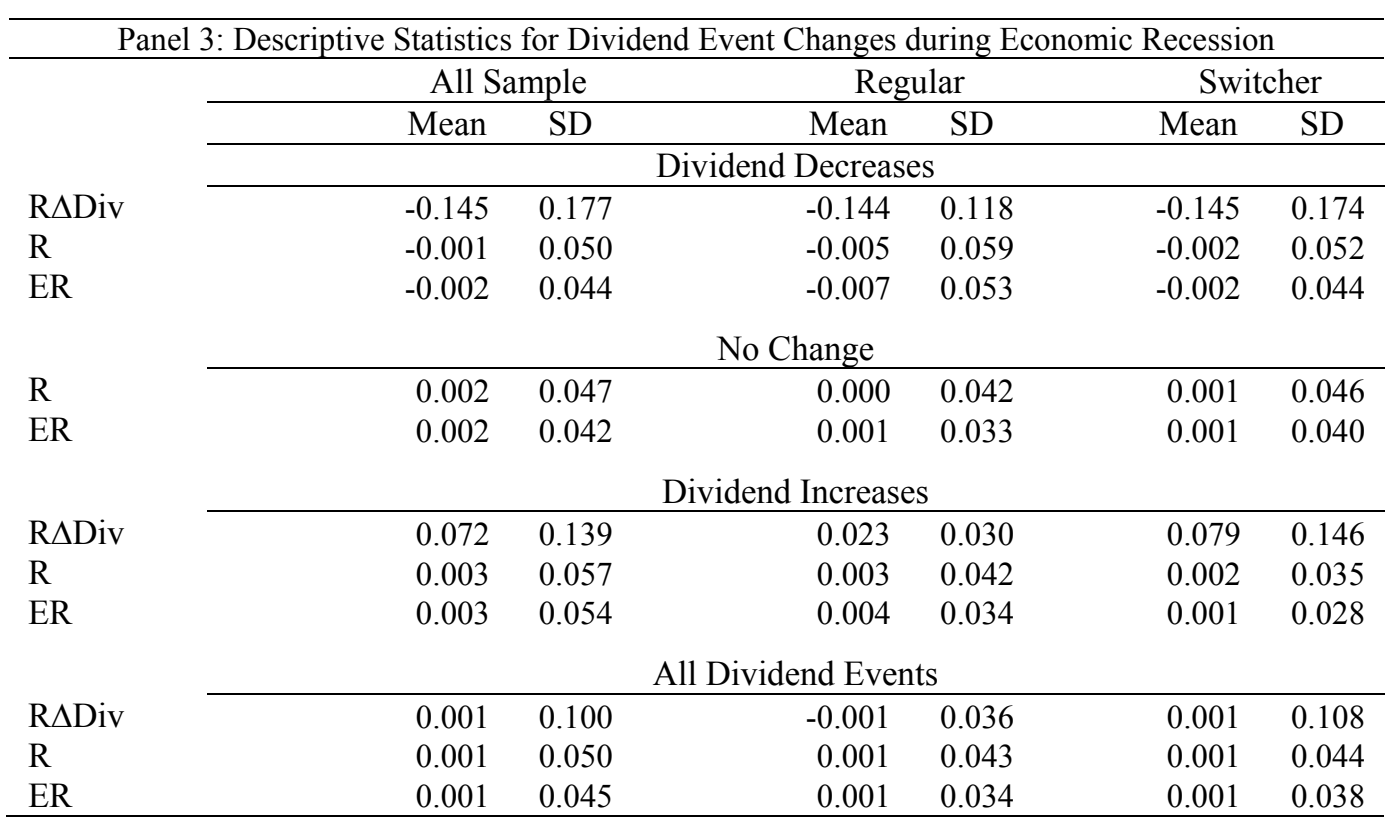

\subsection{Summary and Conclusions}

Using logistic regressions, and controlling for various determining factors of dividend payment identified in previous literature, we found that the dividend paying history of a firm as well as the economic cycle determines whether a firm will change the level of the dividend. Switcher firms are less likely to change dividend levels, but when they do change dividend levels, they tend to change them by large amounts. Regular dividend payers, on the other hand, are more likely to change dividend levels, but by smaller amounts. Expansions are also likely to cause increases in dividend levels, but this may be due to the likelihood of switchers and nonpayers initiating and increasing dividend levels.

We have seen that the importance of the factors that are used to explain returns, namely, the market risk premium, SMB, and HML, change with the dividend paying 
status of the firms. These factors seem to be significant for firms that regularly pay dividend, or sporadically pay dividends (switcher firms), but are not significant for nonpayer firms.

Although non-dividend paying firms have higher returns in excess of the risk free rate, dividend paying firms and switcher firms have positive and significant abnormal returns. Nonpayer firms have abnormal returns that are not significantly different from zero.

We established that Switcher firms issue the largest average dividend decreases, as well as the largest average dividend increases. The results also show that average returns and average excess returns are lower surrounding a dividend decrease declaration, and higher surrounding a dividend increase declaration. In comparing average returns and average excess returns (daily frequency) before and during the market downturn, we see that the market reacts more to dividend events during the downturn. In fact, returns were much lower and always negative surrounding a dividend decreases. On the other hand, they were much higher surrounding a dividend increase. Even if firms did not change their dividend levels, returns surrounding dividend declarations were higher during the downturn. Apparently, the effect of a dividend change is affected by the state of the economy. The results show a magnification effect when the economy is in a bad state. 


\section{CHAPTER 4: DETERMINANTS OF DIVIDEND INCREASES OR DECREASES OF ADRs AND THE EFFECTS ON RETURNS}

\subsection{Introduction}

Examination of a typical dividend paying firm will reveal that dividends are paid quarterly and the amount of cash dividend per share does not fluctuate, in fact it usually remains at the same level for very long periods of time. In most cases, a dividend paying firm has a very long history of paying dividends. Brav, Graham, Harvey, and Michaely (2005) find that most regular, dividend-paying firms continue to pay dividends because they feel obligated to do so due to their long history of paying dividends. In fact, they no longer adhere to target dividend payout ratios, instead they rely on past dividend levels when determining the firm's distribution policy.

Many studies have found a decreasing number of dividend paying firms (Skinner (2008); DeAngelo, DeAngelo, and Skinner (2004); Fama and French (2001)). Instead of cash dividends, more and more firms are using stock repurchases.

However, if regular-dividend paying firms are relying on past dividend levels in determining the firm's distribution policy, then a change in the dividend level of these firms should imply important information about the firm itself. This is especially true when investors are uncertain about future market conditions. Uncertainty is even greater for a foreign based firm, especially if the firm is based in an emerging market. The recent market downturn also increased uncertainty, implying that any dividend changes indicate fundamental changes of important consequences for the firm's future.

The literature regarding American Depository Receipts is abundant. There are many studies that examine the reasons for foreign firms cross-listing in the US. Other 
studies examine the differences between firms in the various ADR levels. A few examine returns behavior of ADRs surrounding the ex-dividend day. Denis and Osobov (2008) provide evidence on the determinants of dividend policy on an international scale, but only look at developed markets. Very few studies have examined the determinants of dividend changes, and as far as we know, this is the first study to identify the determinants of dividend changes in both developed and emerging markets. Even fewer studies have examined the effect of dividend changes on returns.

This study identifies determinants of a change in dividend levels of foreign firms trading on US exchanges in the forms of American Depository Receipts (ADRs) (See the Appendix for a primer on ADRs). An additional innovative aspect of this paper is our examination the effects of changes in dividend levels on returns based on the dividend paying status of the firm (regular, switcher, or nonpayer).

\subsection{Review of Literature}

It is widely accepted that cross-listing increase market integration, and many argue that it can improve market quality in emerging markets. Forester and Karolyi (1998, 2000) and Domowitz, Glen, and Madhavan (1998), as well as others find that cross-listing increases competition for order flow, which improves liquidity. Decreases in cost of capital due to stricter disclosure standards and better legal protection in the US have also been associated with cross-listing (Moel, 1999). More recent studies (Moel, 2001) have found that ADRs originating from emerging markets are related to the weakening of the home markets.

Karolyi (2004) reexamines the role of ADRs in the development of emerging markets. Contrary to previous findings that ADRs lead to the deterioration of the 
financial markets in the emerging markets, he finds evidence that firms list abroad because of the poor and deteriorating quality of financial markets in the home country. ADRs are an effect of weakening home markets rather than a cause of them.

Although, markets have become increasingly open and capital flows have become more fluid, the degree of market segmentation may still be an important determinant of ADR returns. Harvey (1995) finds that local information plays a larger role in emerging markets than in developed markets. Choi and Kim (2000) also find the MSCI Index to have low explanatory power for emerging markets.

Previous studies have found that country factors and macro-economic factors are significant factors that differentiate returns on US stocks and returns on ADRs. Jiang (1998) and Bekaert and Urias (1999) make the case for ADRs as diversification tools. Jiang (1998) identifies a "country" element and a "currency" element that provide diversification. Lesssard (1974) and Roll (1992) argue that diversification benefits come from industrial structure, while Heston and Rouwenhorst (1994), Griffin and Karolyi (1998), and Choi and Kim (2000) find that diversification also comes from country factors or economic policy differences such as interest rate policies, national deficits, monetary policies, and economic growth. Using different multifactor models to explain ADR returns, Patro (2000) also notes that home country returns are important. He finds that a model with home country returns and world returns as risk factors performs better than a model with either factor alone.

Studies related to dividends with respect to ADRs only examine the ex-dividend day in an attempt to measure dividend recapture. Gorman, Mahajan, and Weigand (2004) compare dividend recapture in ADRs to dividend recapture in US stocks. They find that 
ex-day returns for ADRs are higher than the returns for comparable US firm. Also, volume is lower for ADRs than for US firms. They present evidence that a foreign risk premium cannot be the only cause for the higher returns. This implies that dividend recapture is being hindered by other factors. Although they do not expand on the idea, they suggest that differences in dividend payment policies among the different countries may be causing the differences between US stock and ADR ex-day returns.

\subsection{Data}

Daily data on returns of US stocks and ADRs trading on the NYSE, Nasdaq, and AMEX exchanges, and issued by the Bank of New York Mellon, is gathered from the CRSP database. Data on dividend announcement dates is also available from the CRSP database. Data on the cash dividend amounts are available from the Compustat database. In order to be included in our sample, data on returns must be available from the CRSP database and fundamental data must be available from the COMPUSTAT database. As in the previous chapters, a firm is classified as a dividend payer if it has paid a dividend classified as a "regular, quarterly, cash dividend" and coded as " 1232 " by the CRSP database in every quarter for the previous twelve quarters. If the firm paid dividends sporadically over the previous twelve quarters, then it is classified as a switcher firm. If a firm paid no dividends coded as " 1232 ," in the previous twelve quarters, then it is classified as a non-dividend paying firm.

As previous studies have shown, country factors have high explanatory powers for ADR returns. This leads us to believe that such country factors may also be important determinants of dividend changes for ADRs. Therefore, we create a quarterly measure for economic recession for each country using various macro-economic factors. From the 
Datastream database, we gather data on various economic indicators in order to determine the economic conditions in the various home countries of the ADRs. We gather data on unemployment, GDP, GNI, retail sales, and industrial production. We define an economic recession as two consecutive quarters of a decline in GDP, GNI, retail sales, and industrial production, along with two consecutive quarters of an increase in the unemployment rate. This measure is used in attempt to examine whether these factors are related to the propensity to pay dividends and to dividend level changes.

\subsection{Methodology}

The main contribution of this chapter is to identify the determinants of dividend payment and dividend level changes for American Depository Receipts. This is especially challenging because these securities represent ownership in shares of non-U.S. companies. Although they're priced in dollars and pay dividends in dollars, the value of ADRs really depends on the value of the foreign firm and conditions in foreign markets. Another difficulty is introduced by the very few regular, quarterly, cash dividends paid by ADRs.

Table 23 shows that between 1990 and 2009, there were only a couple hundred dividend payments made by regular dividend payers and switchers each. Between 1993 and 2009, only 549 regular, cash dividend distributions were paid by American Depository Receipts. Most were classified as switchers, implying that very few paid dividends regularly. Of those firms that paid dividends, only a handful changed the dividend level. About seven percent of payers and just two percent of switchers increased the dividend level, while not even $1 \%$ or either regular payers or switchers decreased dividend payments. 
Table 23

Number of Dividend Changes, ADRs (1993Q1 - 2009Q2)

Firms are identified as non-dividend payers if they have not paid a regular cash dividend (distribution code "1232" in the CRSP database) within the last 12 quarters. Firms are identified as dividend payers if they paid a regular cash dividend in the previous 12 quarters. If a firm has paid dividends irregularly within the most recent 12 quarters, it is identified as a "Switcher" firm.

\begin{tabular}{ccccccc}
\hline Status & \multicolumn{2}{c}{ Decrease } & \multicolumn{2}{c}{ Increase } & \multicolumn{2}{c}{ No Change } \\
\hline Nonpayer & 1 & $33.33 \%$ & 0 & $0.00 \%$ & 2 & $66.67 \%$ \\
Payer & 2 & $0.83 \%$ & 17 & $7.05 \%$ & 222 & $92.12 \%$ \\
Switcher & 3 & $0.98 \%$ & 7 & $2.30 \%$ & 295 & $96.72 \%$ \\
\hline
\end{tabular}

Table 24 shows how some quarters had no dividends paid by an ADR. In most cases, only a few firms paid dividends. The number of firms that paid a regular, quarterly cash dividend ranged from zero to just twelve between 1993 and 2009. One noticeable trend is that the number of dividend payments from American Depository Receipts increased through time. This is surprising, as studies have shown the number of dividend paying firms to be decreasing among U.S. firms.

Although regular, quarterly cash dividends are not common among ADRs, they are quote volatile, and are paid without consistency by the firms. Table 25 displays summary statistics for dividend payments made between 1993 and 2009. Panel 1 focuses on the dividend payment per share. Regular, quarterly cash dividend payments of ADRs are similar in amount to those of U.S. firms.

Panel 2 highlights changes in the dividend level from one quarter to the another, while Panel 3 shows summary statistics of the percentage change in dividend levels from quarter to quarter. Although the average change in dividends is only $1 \%$ for regular dividend payers, it is a large $12.41 \%$ for a firm that pays dividends sporadically. Large 
Table 24

\section{Number of Dividend Changes Over Time, ADRs (1993Q1 - 2009Q2)}

Firms are identified as non-dividend payers if they have not paid a regular cash dividend (distribution code "1232" in the CRSP database) within the last 12 quarters. Firms are identified as dividend payers if they paid a regular cash dividend in the previous 12 quarters. If a firm has paid dividends irregularly within the most recent 12 quarters, it is identified as a "Switcher" firm.

\begin{tabular}{|c|c|c|c|c|c|c|c|}
\hline $\begin{array}{l}\text { Year \& } \\
\text { Quarter }\end{array}$ & Decrease & Increase & $\begin{array}{c}\text { No } \\
\text { Change }\end{array}$ & $\begin{array}{l}\text { Year \& } \\
\text { Quarter }\end{array}$ & Decrease & Increase & $\begin{array}{c}\text { No } \\
\text { Change }\end{array}$ \\
\hline 1993Q1 & & & 2 & 2001Q2 & & & \\
\hline 1993Q2 & & & 3 & 2001Q3 & & & \\
\hline 1993Q3 & & & 1 & 2001Q4 & & & 2 \\
\hline 1993Q4 & & & 1 & 2002Q1 & & & \\
\hline 1994Q1 & & & 1 & 2002Q2 & & & 1 \\
\hline 1994Q2 & & & 2 & 2002Q3 & & & 1 \\
\hline 1994Q3 & & & 5 & 2002Q4 & 1 & & 3 \\
\hline 1994Q4 & & & 3 & 2003Q1 & & & 2 \\
\hline 1995Q1 & & & 2 & 2003Q2 & & & 4 \\
\hline 1995Q2 & & & & 2003Q3 & & & 4 \\
\hline 1995Q3 & & & 3 & 2003Q4 & & & 4 \\
\hline 1995Q4 & & 1 & 1 & 2004Q1 & & & 4 \\
\hline 1996Q1 & & & 1 & 2004Q2 & & 1 & 6 \\
\hline 1996Q2 & & & 5 & 2004Q3 & & & 4 \\
\hline 1996Q3 & & & 2 & 2004Q4 & & & 5 \\
\hline 1996Q4 & & & & 2005Q1 & & 1 & 3 \\
\hline 1997Q1 & & & & 2005Q2 & & 1 & 6 \\
\hline 1997Q2 & & & & 2005Q3 & & & 4 \\
\hline 1997Q3 & & & 2 & 2005Q4 & & & 6 \\
\hline 1997Q4 & & 1 & & 2006Q1 & & 2 & 3 \\
\hline 1998Q1 & & & 1 & 2006Q2 & & 1 & 7 \\
\hline 1998Q2 & & & 1 & 2006Q3 & & & 5 \\
\hline 1998Q3 & & & & 2006Q4 & & & 7 \\
\hline 1998Q4 & & & & 2007Q1 & 1 & 2 & 4 \\
\hline 1999Q1 & & & 2 & 2007Q2 & & & 8 \\
\hline 1999Q2 & & & 1 & 2007Q3 & & & 6 \\
\hline 1999Q3 & & & 1 & 2007Q4 & & & 7 \\
\hline 1999Q4 & & & 2 & 2008Q1 & & 2 & 5 \\
\hline 2000Q1 & & & & 2008Q2 & & 1 & 6 \\
\hline 2000Q2 & & & 1 & 2008Q3 & & & 6 \\
\hline 2000Q3 & & & & 2008Q4 & & & 6 \\
\hline 2000Q4 & & & 1 & 2009Q1 & & 2 & 5 \\
\hline 2001Q1 & & & 2 & 2009Q2 & & 1 & 6 \\
\hline
\end{tabular}


Table 24 (continued)

\begin{tabular}{|c|c|c|c|c|c|c|c|}
\hline \multicolumn{8}{|c|}{ Panel 2: Dividend Changes for Switchers } \\
\hline $\begin{array}{l}\text { Year \& } \\
\text { Quarter }\end{array}$ & Decrease & Increase & $\begin{array}{c}\text { No } \\
\text { Change }\end{array}$ & $\begin{array}{l}\text { Year \& } \\
\text { Quarter }\end{array}$ & Decrease & Increase & $\begin{array}{c}\text { No } \\
\text { Change }\end{array}$ \\
\hline 1993Q1 & & & 2 & 2001Q2 & & & 4 \\
\hline 1993Q2 & & & 2 & 2001Q3 & & & \\
\hline 1993Q3 & & & 2 & 2001Q4 & & & 4 \\
\hline 1993Q4 & & & 2 & 2002Q1 & & & 3 \\
\hline 1994Q1 & & & 1 & 2002Q2 & & & \\
\hline 1994Q2 & & & 2 & 2002Q3 & & & 3 \\
\hline 1994Q3 & & & 2 & 2002Q4 & & 1 & 9 \\
\hline 1994Q4 & & & & 2003Q1 & & & 4 \\
\hline 1995Q1 & & & & 2003Q2 & & 1 & 7 \\
\hline 1995Q2 & & & 1 & 2003Q3 & & & 4 \\
\hline 1995Q3 & & & & 2003Q4 & & & 5 \\
\hline 1995Q4 & & & 1 & 2004Q1 & & & 4 \\
\hline 1996Q1 & & & 1 & 2004Q2 & & & 6 \\
\hline 1996Q2 & & & 2 & 2004Q3 & & & 4 \\
\hline 1996Q3 & & & & 2004Q4 & & 1 & 2 \\
\hline 1996Q4 & & & 1 & 2005Q1 & & & 6 \\
\hline 1997Q1 & & & & 2005Q2 & & & 6 \\
\hline 1997Q2 & & & 3 & 2005Q3 & & 1 & 4 \\
\hline 1997Q3 & & & 1 & 2005Q4 & & & 8 \\
\hline 1997Q4 & & & 5 & 2006Q1 & & & 4 \\
\hline 1998Q1 & & & & 2006Q2 & & & 6 \\
\hline 1998Q2 & & & 3 & 2006Q3 & & & 5 \\
\hline 1998Q3 & & & 3 & 2006Q4 & & & 8 \\
\hline 1998Q4 & & & 1 & 2007Q1 & & & 3 \\
\hline 1999Q1 & & & 4 & 2007Q2 & & & 9 \\
\hline 1999Q2 & & & 2 & 2007Q3 & & & 6 \\
\hline 1999Q3 & & & 3 & 2007Q4 & & & 9 \\
\hline 1999Q4 & & & 1 & 2008Q1 & & & 8 \\
\hline 2000Q1 & & & 3 & 2008Q2 & & 1 & 11 \\
\hline 2000Q2 & & & 5 & 2008Q3 & & & 10 \\
\hline 2000Q3 & & & 2 & 2008Q4 & 2 & & 10 \\
\hline 2000Q4 & & & & 2009Q1 & & & 12 \\
\hline 2001Q1 & & & 3 & 2009Q2 & 1 & 1 & 7 \\
\hline
\end{tabular}


Summary Statistics of Dividend Payment Level, Change, and Percentage Change, ADRs Firms are identified as non-dividend payers if they have not paid a regular cash dividend (distribution code "1232" in the CRSP database) within the last 12 quarters. Firms are identified as dividend payers if they paid a regular cash dividend in the previous 12 quarters. If a firm has paid dividends irregularly within the most recent 12 quarters, it is identified as a "Switcher" firm.

\begin{tabular}{lcccc}
\hline \multicolumn{5}{c}{ Panel 1: Dividend Payment } \\
\hline Status & Mean & Median & Minimum & Maximum \\
\hline Nonpayer & 0.30 & 0.18 & 0.03 & 0.84 \\
Dividend Payer & 0.34 & 0.34 & 0.02 & 1.00 \\
Switcher & 0.20 & 0.13 & 0.02 & 0.84 \\
& \multicolumn{5}{c}{} \\
\hline \multicolumn{5}{c}{ Panel 2: Dividend Change } \\
\hline Status & Mean & Median & Minimum & Maximum \\
\hline Nonpayer & 0.039 & 0 & 0 & 0.116 \\
Dividend Payer & 0.002 & 0 & 0 & 0.120 \\
Switcher & 0.019 & 0 & 0 & 0.253 \\
& \multicolumn{5}{c}{} \\
\hline \multicolumn{5}{c}{ Panel 3: Dividend Percent Change } \\
\hline Status & Mean & Median & Minimum & Maximum \\
\hline Nonpayer & $5.36 \%$ & $0.00 \%$ & $0.00 \%$ & $16.09 \%$ \\
Dividend Payer & $1.05 \%$ & $0.00 \%$ & $0.00 \%$ & $71.43 \%$ \\
Switcher & $12.41 \%$ & $0.00 \%$ & $0.00 \%$ & $139.55 \%$ \\
\hline
\end{tabular}

swings in dividend payments are also evident among all types of firms. Even regular dividend paying firms have changed their dividend by as much as $71.43 \%$, while switchers have made a $139.55 \%$ change. Such wide swings stem from the very few dividend payments among ADRs.

In order to determine if an American Depository Receipt will increase, decrease, or leave the dividend level unchanged, a polytomous logistic regression is used. This type of regression allows us to use a dependent variable of two or more responses.

As in Chapter 2, our response row is

$$
y_{i}=\left(y_{i 1}, y_{i 2}, \ldots, y_{i r}\right)^{T}
$$


We assume a multinomial distribution with index $n_{i}=\sum_{j=1}^{r} y_{i j}$ and parameter $\pi_{i}=\left(\pi_{i 1}, \pi_{i 2}, \ldots, \pi_{i r}\right)^{T}$. We relate $\pi_{i}$ to covariates through a set of $\mathrm{r}-1$ baseline-category logits. Taking $\mathrm{j}^{*}$ as the baseline category, the model is

$$
\log \left(\frac{\pi_{i j}}{\pi_{i j^{*}}}\right)=x_{i}^{T} \beta_{j}, \quad j \neq j^{*} .
$$

If $\mathrm{x}_{\mathrm{i}}$ has length $\mathrm{p}$, then the model has $(r-1) \times p$ free parameters, which we can arrange as a matrix or a vector. The last category is the baseline $\left(j^{*}=r\right)$, so the coefficients are

$$
\beta=\left[\beta_{1}, \beta_{2}, \ldots, \beta_{r-1}\right]
$$

Or

$$
\operatorname{vec}(\beta)=\left[\begin{array}{c}
\beta_{1} \\
\beta_{2} \\
\vdots \\
\beta_{r-1}
\end{array}\right] .
$$

The kth element of $\beta_{j}$ can be interpreted as: the increase in log-odds of falling into category $\mathrm{j}$ versus category $\mathrm{j}^{*}$ resulting from a one-unit increase in the kth covariate, holding the other covariates constant.

\subsection{Empirical Results}

The predictors of interest include the firm's dividend paying status, the state of the economy, the firm's total assets, growth opportunities, earned equity, and profitability. Table 26 displays the mean values for total assets, market value, profitability, earned equity, and growth opportunities according to the dividend paying status of the firm and whether the firm has increased, decreased, or left the dividend level unchanged. Because there were only three instances where a non-dividend paying firms paid dividends, there is also a column labeled "Never Paid" for the nonpayer status, which allows for comparison of firms that never paid dividends. 
Of the firms that paid dividends, regular dividend paying firms had the highest average total assets, market value, profitability, earned equity, and even growth opportunities. This is a bit surprising because high growth opportunities have been associated with a lower probability of dividend payment. This may be explained by the fact that these ADR firms are still expanding into the world markets, so reimbursement, rather than distribution, of earnings is more important. Also, the table shows that regular dividend paying firms with the highest growth opportunities decreased dividends, most likely to increase reinvestment and take advantage of the growth opportunities available. The same can be said of switcher firms, which seem to exhibit the same pattern.

Non-dividend paying ADRs that have never paid a dividend display some surprising characteristics. They have, by far, the highest total assets, market value, profitability, and earned equity; all characteristics that are associated with dividend payment. Growth opportunities are high, but similar to those of regular dividend payers.

Table 27 introduces economic conditions and allows us to see how determinants of dividends are different depending on the state of the economy and the dividend paying status of the firm. Naturally, during a recession, total assets and market value are lower, on average. Surprisingly, profitability, earned equity, and growth opportunities are higher, on average, during a recession. Average profitability and earned equity are also higher for regular dividend payers during a recession. What is surprising, however, is the increase in average total assets seen during recessions. This is also exhibited in Chapter 2 with U.S. firms. Dividend paying firms may be viewed as safer stocks during a recession. This may be occur even more so for ADRs. ADRs tend to be the largest, most profitable within their home country. Cross-listing on a major exchange like the NYSE, 


\section{Table 26}

\section{Summary Statistics of Dividend Determinants According to Dividend Paying Status, ADRs}

The Total Assets are reported in millions of US dollars and are equal to the book value of total assets. Growth Opportunities 1 is calculated as the ratio of the market value of total capital to the book value of total assets ((book value of total assets-book value of equity + market value of equity)/book value of total assets). Growth Opportunities 2 is calculated as the percent change in assets over the quarter. Earned Equity is calculated as ratio of retained earnings to the book value of equity. Profitability 1 is calculated as the ratio of earnings before interest to the book value of total assets. Profitability 2 is calculated as the ratio of after-tax earnings to the book value of equity. Firms are identified as non-dividend payers if they have not paid a regular cash dividend (distribution code "1232" in the CRSP database) within the last 12 quarters. Firms are identified as dividend payers if they paid a regular cash dividend in the previous 12 quarters. If a firm has paid dividends irregularly within the most recent 12 quarters, it is identified as a "Switcher" firm.

\begin{tabular}{|c|c|c|c|c|c|c|c|c|c|c|}
\hline & \multicolumn{4}{|c|}{ Nonpayer } & \multicolumn{3}{|c|}{ Payer } & \multicolumn{3}{|c|}{ Switcher } \\
\hline & Decrease & Increase & $\begin{array}{c}\text { No } \\
\text { Change }\end{array}$ & $\begin{array}{c}\text { Never } \\
\text { Paid }\end{array}$ & Decrease & Increase & $\begin{array}{c}\text { No } \\
\text { Change }\end{array}$ & Decrease & Increase & $\begin{array}{c}\text { No } \\
\text { Change }\end{array}$ \\
\hline Total Assets & $5,116.00$ & - & $9,767.90$ & $69,908.67$ & $16,115.15$ & $13,237.46$ & $11,148.12$ & $9,085.64$ & $8,055.03$ & $5,809.01$ \\
\hline Market Value & $3,619.50$ & - & $2,516.17$ & $19,542.77$ & $4,799.14$ & $6,401.24$ & $5,142.08$ & $4,128.56$ & $3,589.07$ & $3,069.75$ \\
\hline Profitability 1 & 0.022 & - & -0.004 & 0.014 & 0.043 & 0.025 & 0.010 & 0.026 & 0.016 & 0.010 \\
\hline Profitability 2 & 0.043 & - & -0.030 & 76.225 & 1.069 & 0.323 & 0.042 & 3.491 & 0.182 & 0.031 \\
\hline Earned Equity & 0.136 & - & -0.048 & 2198.762 & 0.534 & 0.643 & 0.786 & 0.187 & 0.447 & 0.437 \\
\hline Growth Opportunities 1 & 0.707 & - & 0.769 & 1.579 & 2.443 & 1.322 & 0.820 & 1.582 & 0.889 & 0.773 \\
\hline Growth Opportunities 2 & 0.000 & - & -0.002 & -1.201 & -14.505 & -3.214 & -1.680 & -9.867 & -1.221 & -0.269 \\
\hline
\end{tabular}


Table 27

\section{Summary Statistics of Dividend Determinants According to Dividend Paying Status and Economic Cycle, ADRs}

The Total Assets are reported in millions of US dollars and are equal to the book value of total assets. Growth Opportunities 1 is calculated as the ratio of the market value of total capital to the book value of total assets ((book value of total assets-book value of equity + market value of equity)/book value of total assets). Growth Opportunities 2 is calculated as the percent change in assets over the quarter. Earned Equity is calculated as ratio of retained earnings to the book value of equity. Profitability 1 is calculated as the ratio of earnings before interest to the book value of total assets. Profitability 2 is calculated as the ratio of after-tax earnings to the book value of equity. Firms are identified as non-dividend payers if they have not paid a regular cash dividend (distribution code "1232" in the CRSP database) within the last 12 quarters. Firms are identified as dividend payers if they paid a regular cash dividend in the previous 12 quarters. If a firm has paid dividends irregularly within the most recent 12 quarters, it is identified as a "Switcher" firm. A quarter is labeled as expansion or recession if it is classified as such by the National Bureau of Economic Research. According to the NBER recessions occurred between March 2001 and November 2001 and between December 2007 and June 2009.

\begin{tabular}{|c|c|c|c|c|c|c|c|c|}
\hline & \multicolumn{4}{|c|}{ Expansion } & \multicolumn{4}{|c|}{ Recession } \\
\hline & Decrease & Increase & No Change & Never Paid & Decrease & Increase & No Change & Never Paid \\
\hline & \multicolumn{8}{|c|}{ Nonpayer } \\
\hline Total Assets & $5,116.00$ & - & $9,767.90$ & $40,263.70$ & - & - & - & $39,235.04$ \\
\hline Market Value & $3,619.50$ & - & $2,516.17$ & $17,461.39$ & - & - & - & $17,054.64$ \\
\hline Profitability 1 & 0.02 & - & 0.00 & 0.02 & - & - & - & 0.02 \\
\hline Profitabilty 2 & 0.04 & - & -0.03 & 0.02 & - & - & - & 0.04 \\
\hline Earned Equity & 0.14 & - & -0.05 & 0.21 & - & - & - & 0.34 \\
\hline Growth Opportunities 1 & 0.71 & - & 0.77 & 2.04 & - & - & - & 1.22 \\
\hline Growth Opportunities 2 & 0.00 & - & 0.00 & -0.84 & - & - & - & -0.24 \\
\hline
\end{tabular}


Table 27 (continued)

\begin{tabular}{|c|c|c|c|c|c|c|c|c|}
\hline & \multicolumn{4}{|c|}{ Expansion } & \multicolumn{4}{|c|}{ Recession } \\
\hline & Decrease & Increase & No Change & Never Paid & Decrease & Increase & No Change & Never Paid \\
\hline & \multicolumn{8}{|c|}{ Payer } \\
\hline Total Assets & 764.63 & $41,912.65$ & $20,281.76$ & - & - & $42,611.03$ & $23,351.02$ & - \\
\hline Market Value & 541.29 & $27,491.15$ & $29,990.14$ & - & - & $19,382.33$ & $29,155.29$ & - \\
\hline Profitability 1 & 0.04 & 0.01 & 0.01 & - & - & 0.01 & 0.03 & - \\
\hline Profitabilty 2 & 0.04 & 0.03 & 0.04 & - & - & 0.05 & 0.07 & - \\
\hline Earned Equity & 0.28 & 0.77 & 0.29 & - & - & 0.74 & 0.85 & - \\
\hline Growth Opportunities 1 & 0.71 & 0.70 & 1.60 & - & - & 0.60 & 1.03 & - \\
\hline \multirow[t]{2}{*}{ Growth Opportunities 2} & -0.99 & 0.00 & -12.00 & - & - & 0.00 & 0.00 & - \\
\hline & \multicolumn{8}{|c|}{ Switcher } \\
\hline Total Assets & - & - & $16,029.08$ & - & $57,347.06$ & $56,801.30$ & $14,895.19$ & - \\
\hline Market Value & - & - & $13,628.66$ & - & $25,733.97$ & $38,610.95$ & $6,745.16$ & - \\
\hline Profitability 1 & - & - & 0.02 & - & -0.04 & 0.04 & 0.01 & - \\
\hline Profitabilty 2 & - & - & 0.05 & - & -0.06 & 0.06 & 0.04 & - \\
\hline Earned Equity & - & - & 0.34 & - & 0.74 & 0.42 & 0.46 & - \\
\hline Growth Opportunities 1 & - & - & 1.71 & - & 0.45 & 0.68 & 0.41 & - \\
\hline Growth Opportunities 2 & - & - & -4.93 & - & 0.00 & 0.00 & 0.00 & - \\
\hline
\end{tabular}


NASDAQ, or AMEX increases these firms association with financial security. Another point of interest is that no dividend payer decreased a dividend payment during a recession. On the other hand, decreases were seen in expansionary periods. This is also similar to results in Chapter 2, where U.S. firms were more likely to decrease a dividend during an expansionary period. Average growth opportunities also decreased during economic contractions, limiting what firms could earn with reinvestment, which may have allowed for a dividend increase.

Switcher firms neither increased nor decreased dividends during economic expansions. These sporadic dividend payers were more likely to make changes during economic contractions. Total assets, market value, profitability, and growth opportunities decreased for switcher firms during economic recessions, but firms that increased or decreased dividend levels had market values and total assets that were far higher than those of the average switcher firm. Firms that increased dividends also had growth opportunities higher than those of the average firm.

Table 28 displays results of a polytomous logistic regression where the response variable is

$$
Y_{i}=\left\{\begin{array}{l}
1 \text { if the dividend increases } \\
2 \text { if the dividend decreases } \\
3 \text { if the dividend remains unchanged }
\end{array}\right.
$$

Predictor variables include dividend paying status, the state of the economy, total assets, earned equity, growth opportunities, and profitability. Non-dividend payers are excluded from this analysis as there are only three instances where a non-dividend payer distributed dividends. 
Table 28

\section{Generalized Logarithmic Regressions with Growth Opportunities 1 and Profitability 1, ADRs}

The probability modeled is that Change $=$ 'No Change'. Using a polytomous logit model, variables are selected using a generalized logit procedure and Newton-Raphson optimization technique. The Status effect is represented by a two binary variables: Payer. The binary variable "Payer" is equal to 1 if the firm has paid a regular cash dividend (distribution code "1232" in the CRSP database) in all of the previous 12 quarters, and it is equal to 0 otherwise. We measure the effect of the market according to the expansion and contractions measured through GDP, GNI, Unemployment, Industrial Production, and Retail Sales. The Economic Cycle effect is introduced as a binary variable called Expansion that is equal to 1 if the market is in an expansionary quarter and 0 when the market is in a contraction or recession period. Total Assets is the book value of total assets in the prior quarter. Growth Opportunities 1 is calculated as the ratio of the market value of total capital to the book value of total assets ((book value of total assets-book value of equity + market value of equity)/book value of total assets) in the prior quarter. Profitability 1 is calculated as the ratio of earnings before interest to the book value of total assets in the prior quarter.

\begin{tabular}{|c|c|c|c|c|c|c|c|c|c|}
\hline \multicolumn{4}{|c|}{ Panel 1: Fit Statistics } & & & & & & \\
\hline Criterion & $\begin{array}{l}\text { Intercept } \\
\text { Only }\end{array}$ & \multicolumn{2}{|c|}{$\begin{array}{c}\text { Intercept And } \\
\text { Covariates }\end{array}$} & & & & & & \\
\hline AIC & 74 & \multicolumn{2}{|r|}{73} & & & & & & \\
\hline $\mathrm{SC}$ & 81 & \multicolumn{2}{|c|}{120} & & & & & & \\
\hline$-2 \log L$ & 70 & \multicolumn{4}{|c|}{45} & & & & \\
\hline \multicolumn{10}{|c|}{ Panel 2: Analysis of Effects with Effect Coding } \\
\hline \multicolumn{2}{|c|}{ Effect } & \multicolumn{2}{|c|}{$\begin{array}{ll} & \text { Wald } \\
\text { DF } & \text { ChiSa }\end{array}$} & \multicolumn{2}{|c|}{$\begin{array}{l}\text { Prob } \\
\text { ChiSq }\end{array}$} & & & & \\
\hline \multicolumn{2}{|l|}{ Status } & 2 & 3.55 & \multicolumn{2}{|c|}{0.1697} & & & & \\
\hline \multicolumn{2}{|c|}{ Economic Cycle } & 2 & 10.34 & \multicolumn{2}{|c|}{0.0057} & & & & \\
\hline Total Ass & & 2 & 4.79 & \multicolumn{2}{|c|}{0.0911} & & & & \\
\hline Growth $\mathrm{C}$ & rtunities1 & 2 & 2.23 & \multicolumn{2}{|c|}{0.328} & & & & \\
\hline Earned E & & 2 & 0.95 & \multicolumn{2}{|c|}{0.621} & & & & \\
\hline Profitabil & & 2 & 3.19 & \multicolumn{2}{|c|}{0.203} & & & & \\
\hline \multicolumn{10}{|c|}{ Panel 3: Parameter Estimates with Effect Coding } \\
\hline \multicolumn{2}{|c|}{ Variable } & ClassVal0 & & onse & DF & Estimate & StdErr & $\begin{array}{l}\text { Wald } \\
\text { ChiSq }\end{array}$ & $\begin{array}{l}\text { Prob } \\
\text { ChiSq }\end{array}$ \\
\hline Intercept & & & Des & case & 1 & -4.21 & 1.54 & 7.43 & 0.0064 \\
\hline Intercept & & & Inc & & 1 & -3.22 & 1.45 & 4.94 & 0.0262 \\
\hline Status & & Payer & Dec & ase & 1 & 0.40 & 0.81 & 0.24 & 0.6241 \\
\hline Status & & Payer & Inc & & 1 & 1.64 & 0.89 & 3.40 & 0.0652 \\
\hline Economi & & Expansion & Dec & ase & 1 & -1.36 & 0.77 & 3.10 & 0.0781 \\
\hline Economi & & Expansion & Inc & & 1 & -1.98 & 0.70 & 7.99 & 0.0047 \\
\hline Total As: & & & Dec & ase & 1 & 0.00 & 0.00 & 0.51 & 0.4742 \\
\hline Total Ass & & & Inc & & 1 & 0.00 & 0.00 & 4.44 & 0.0352 \\
\hline Growth $\mathrm{C}$ & rtunities & & Des & ase & 1 & -0.73 & 1.69 & 0.18 & 0.668 \\
\hline Growth $C$ & rtunities & & Inc & & 1 & -4.51 & 3.12 & 2.09 & 0.1479 \\
\hline Earned $\mathrm{E}$ & & & De & ase & 1 & 0.40 & 1.20 & 0.11 & 0.7371 \\
\hline Earned $\mathrm{E}$ & & & Inc & & 1 & 0.84 & 0.90 & 0.89 & 0.346 \\
\hline Profitabil & & & De & ase & 1 & 16.89 & 24.24 & 0.49 & 0.486 \\
\hline Profitabil & & & Inc & & 1 & 39.68 & 23.67 & 2.81 & 0.0937 \\
\hline
\end{tabular}


Table 28 (continued)

\begin{tabular}{llrrrr}
\hline \multicolumn{5}{c}{ Panel 4: Odds Ratio Estimates } \\
\hline \multicolumn{7}{c}{ Effect } & Response & OddsRatioEst & LowerCL & UpperCL \\
\hline Status & Payer vs Switcher & Decrease & 2.203 & 0.094 & 51.886 \\
Status & Payer vs Switcher & Increase & 26.556 & 0.813 & 867.069 \\
Economic Cycle & Expansion vs Recession & Decrease & 0.066 & 0.003 & 1.357 \\
Economic Cycle & Expansion vs Recession & Increase & 0.019 & 0.001 & 0.297 \\
Total Assets & & Decrease & 1 & 1 & 1 \\
Total Assets & Increase & 1 & 1 & 1 \\
Growth Opportunities & Decrease & 0.484 & 0.018 & 13.342 \\
Growth Opportunities & Increase & 0.011 & $<0.001$ & 4.949 \\
Earned Equity & Decrease & 1.494 & 0.143 & 15.575 \\
Earned Equity & Increase & 2.327 & 0.402 & 13.49 \\
Profitability1 & Decrease & $2.16 \mathrm{E}+07$ & $<0.001$ & $2.16 \mathrm{E}+07$ \\
Profitability1 & Increase & $1.71 \mathrm{E}+17$ & 0.001 & $1.71 \mathrm{E}+17$ \\
\hline
\end{tabular}

The Type III analysis of effects in Panel 2 shows the change in fit that results in excluding one of the covariates. Only the state of the economy has a significant effect on dividend level changes at the $1 \%$ level. This is far different from the results in Chapter 2 for U.S. firms, where most of the dividend determinants were significant in determining dividend level changes. Total assets also has a discernable effect of dividend changes, but only at the $10 \%$ level.

The estimates for intercepts in Panel 3 are the log-odds ratios for Switchers during Recessions. The log-odds of a decrease in the dividend versus no change for switcher firms during a recession is -4.21 , while the log-odds of an increase in the dividend versus no change for switcher firms during a recession is -3.22 . This implies a switcher firm is unlikely to change a dividend level during a recession.

According to the odds ratios in Panel 4, a dividend paying firm is $26.556 \%$ more likely than a switcher to increase a dividend. An economic expansion is likely to cause 
less movement in the dividend levels for ADRs. In an expansion, a firm is $0.066 \%$ less likely to decrease, and $0.019 \%$ less likely to increase, the dividend level than leave it unchanged. A one unit increase in Total Assets increases the likelihood of an increase in the dividend by $1 \%$ over leaving the dividend unchanged. An increase in growth opportunities decreases the likelihood that the dividend level will change. On the other hand a one unit change in profitability, drastically increases the likelihood that the dividend will increase. This result may be a product of the few ADR firms that actually pay dividends and the wide variability in profitability that exists between them.

In order to examine returns of ADRs across dividend paying groups and economic cycles, we employ the Fama-French two-factor model for explaining international returns:

$$
R-F=a+b[M-F]+c[H-L B / M]+e
$$

Where $\mathrm{R}-\mathrm{F}$ is the return, in excess of the US T-bill, on any portfolio, $\mathrm{M}-\mathrm{F}$ is the excess return on the global market, and $\mathrm{H}-\mathrm{LB} / \mathrm{M}$ is the difference between the return on the high book-to-market international portfolio and the low book-to-market international portfolio. Monthly data for the factors in this model is available on Professor Kenneth R. French's data library website.

Table 29 displays parameter estimates for the Fama - French two-factor model for international firms. According to the model, American Depository Receipt firms have significant negative abnormal returns, regardless of the dividend paying status of the firm. The very low R-squares for all ADRs, regular dividend payers, switchers, and nondividend paying ADRs highlight the fact that the Fama-French two-factor model does not adequately explain returns for ADRs. Although this model does very well at explaining 
Fama-French Two Factor Regressions by Dividend-Paying Status, ADRs (1993-2009)

Monthly returns of ADRs are from the CRSP database. Monthly market and book-to-market factors for international firms are from Professor Kenneth French's data library. Regression results for the Fama-French two-factor model $\mathrm{Ri}=$ $\mathrm{ai}+\mathrm{bi}(\mathrm{Rm}-\mathrm{Rf})+$ hiHML + ei are shown below. The number of regular dividend payers ranges from just one in several quarters to a maximum of seven in the second quarter in 2006 through the second quarter in 2008 . The number od switchers ranges from one in several quarters to a maximum of ten in the second quarter of 2008, the fourth quarter of 2009 , and the first quarter of 2009. The number of nonpayers ranges from a minimum of 28 in the first quarter in 1993 to 257 in the second quarter of 2009.

\begin{tabular}{|c|c|c|c|c|c|c|c|}
\hline \multirow[b]{2}{*}{ Sample } & \multicolumn{3}{|c|}{ Estimated Parameter Values } & \multicolumn{3}{|c|}{ T-Values } & \multirow[b]{2}{*}{$\mathrm{R}-\mathrm{Sq}$} \\
\hline & $\mathrm{a}$ & $\mathrm{b}$ & $\mathrm{h}$ & $\mathrm{a}$ & $\mathrm{b}$ & $\mathrm{h}$ & \\
\hline All & -0.290 & 0.011 & 0.007 & -297.84 & 59.30 & 19.22 & 0.081 \\
\hline Regular & -0.252 & 0.011 & 0.008 & -27.34 & 6.29 & 2.61 & 0.111 \\
\hline Switcher & -0.229 & 0.014 & 0.001 & -25.21 & 8.24 & 0.38 & 0.121 \\
\hline Nonpayer & -0.232 & 0.013 & 0.005 & -155.54 & 44.31 & 9.7 & 0.113 \\
\hline
\end{tabular}

returns of international firms (R-square of 97\% (see Fama and French, 1998, Table IV, p

1983)), it can only explain about $8 \%$ of ADR returns. The market and book-to-market

factors are statistically significant (except for the book-to-market factor for switcher

firms), but the intercept is largely significant in all cases, implying misspecification or missing explanatory terms.

Table 30 displays results for two-factor Fama-French regressions for all ADRs, regular dividend payers, and switchers according to the change in dividend levels. Nondividend payers are excluded because there were only three cases where a non-dividend payer paid a dividend. In all cases, except switchers who decreased the dividend level, the model shows significant negative abnormal returns, with dividend payer experiencing the largest negative abnormal returns. Despite these findings, explanatory power is low in most cases. Although dividend payers and switchers who decreased dividends have Rsquares of 0.90 and 0.80 the book-to-market factor in the Fama-French two factor model is insignificant. The same can be said of switchers who increased dividends. 
Fama-French Two Factor Regressions by Dividend-Paying Status and Dividend Change, ADRs (1993-2009)

Monthly returns of ADRs are from the CRSP database. Monthly market and book-to-market factors for international firms are from Professor Kenneth French's data library. Regression results for the Fama-French two-factor model Ri = $\mathrm{ai}+\mathrm{bi}(\mathrm{Rm}-\mathrm{Rf})+$ hiHML + ei are shown below.

\begin{tabular}{|c|c|c|c|c|c|c|c|}
\hline \multirow[b]{2}{*}{ Sample } & \multicolumn{3}{|c|}{ Estimated Parameter Values } & \multicolumn{3}{|c|}{ T-Values } & \multirow{3}{*}{ R-Sq } \\
\hline & $\mathrm{a}$ & $\mathrm{b}$ & $\mathrm{h}$ & $\mathrm{a}$ & $\mathrm{b}$ & $\mathrm{h}$ & \\
\hline \multicolumn{7}{|c|}{ All } & \\
\hline Decrease & -0.222 & 0.019 & -0.005 & -3.7 & 2.32 & -0.4 & 0.29 \\
\hline Increase & -0.199 & 0.012 & 0.008 & -6.72 & 2.1 & 0.86 & 0.16 \\
\hline No Change & -0.250 & 0.009 & 0.012 & -24.28 & 4.61 & 3.37 & 0.11 \\
\hline \multicolumn{8}{|c|}{ Regular } \\
\hline Decrease & -0.454 & 0.037 & 0.009 & -15.48 & 4.8 & 1.1 & 0.90 \\
\hline Increase & -0.212 & 0.010 & 0.000 & -5.94 & 1.54 & 0.03 & 0.07 \\
\hline No Change & -0.262 & 0.010 & 0.012 & -23.4 & 4.67 & 3.06 & 0.12 \\
\hline \multicolumn{8}{|c|}{ Switcher } \\
\hline Decrease & -0.059 & 0.013 & 0.012 & -1.27 & 2.58 & 1.38 & 0.80 \\
\hline Increase & -0.188 & 0.014 & 0.019 & -2.11 & 1.07 & 1.48 & 0.56 \\
\hline No change & -0.175 & 0.005 & 0.024 & -6.82 & 1.12 & 1.98 & 0.15 \\
\hline
\end{tabular}

Table 31 displays results for Fama-French two-factor regressions for all firms according to the dividend paying status of the firm and the state of the economy. Again, all firms, regardless of dividend paying status and economic conditions are shown to have significant negative abnormal returns. In most cases, except for all firms and switchers during economic expansions, the book-to-market factor is insignificant. Once again, we can draw the conclusion that the Fama-French two-factor model to explain returns of international firms cannot explain returns for American Depository Receipts, despite the fact that these are international equity securities. The lack of goodness of fit can be 
Table 31

Fama-French Two Factor Regressions by Dividend-Paying Status and Economic Cycle, ADRs (1993-2009)

Monthly returns of ADRs are from the CRSP database. Monthly market and book-to-market factors for international firms are from Professor Kenneth French's data library. Regression results for the Fama-French two-factor model $\mathrm{Ri}=$ $\mathrm{ai}+\mathrm{bi}(\mathrm{Rm}-\mathrm{Rf})+$ hiHML + ei are shown below.divide the samples into two economic periods to distinguish between recession and non-recession periods. Recessions are defined as two consecutive quarterly declines in GDP, GNI, Industrial Production, and Retail Sales, with the simultaneous increase of Unemployment.

\begin{tabular}{|c|c|c|c|c|c|c|c|}
\hline \multirow[b]{2}{*}{ Sample } & \multicolumn{3}{|c|}{ Estimated Parameter Values } & \multicolumn{3}{|c|}{ T-Values } & \multirow[b]{2}{*}{$\mathrm{R}-\mathrm{Sq}$} \\
\hline & $\mathrm{a}$ & $\mathrm{b}$ & $\mathrm{h}$ & $\mathrm{a}$ & $\mathrm{b}$ & $\mathrm{h}$ & \\
\hline \multicolumn{8}{|c|}{ All } \\
\hline Expansion & -0.34 & 0.01 & -0.01 & -136.03 & 22.16 & -10.01 & 0.09 \\
\hline Recession & -0.26 & 0.01 & 0.00 & -30.00 & 3.02 & -1.42 & 0.02 \\
\hline \multicolumn{8}{|c|}{ Regular } \\
\hline Expansion & -0.39 & 0.01 & 0.00 & -26.57 & 3.62 & -0.79 & 0.10 \\
\hline Recession & -0.27 & 0.02 & 0.04 & -3.83 & 1.41 & 0.92 & 0.36 \\
\hline \multicolumn{8}{|c|}{ Switcher } \\
\hline Expansion & -0.35 & 0.02 & -0.01 & -20.93 & 5.92 & -1.48 & 0.17 \\
\hline Recession & -0.23 & 0.01 & 0.00 & -4.02 & 0.75 & 0.29 & 0.03 \\
\hline \multicolumn{8}{|c|}{ Nonpayer } \\
\hline Expansion & -0.34 & 0.01 & -0.01 & -132.24 & 21.23 & -9.90 & 0.09 \\
\hline Recession & -0.26 & 0.01 & 0.00 & -29.71 & 2.70 & -1.61 & 0.02 \\
\hline
\end{tabular}

explained by the small sample of international firms that are ADRs, and there are only a handful of them that pay dividends.

\subsection{Summary and Conclusions}

In terms of dividend determinants and dividend properties, American Depository

Receipts are very different from equity securities issued by U.S. firms. Although payment amounts are similar in value, regular, quarterly cash dividend distributions are rare among ADRs. There was evidence that dividend payments were increasing in recent times, but they are still very few. 
This study on American Depository Receipts is limited by the lack of regular, quarterly cash dividends, as well as the limited data availability on ADRs. In order to examine dividend determinants, data is needed on firm fundamentals. Although the Datastream database is rich in data on ADRs, key accounting variables needed for this study could only be found on the COMPUSTAT database, which is somewhat limited in that it covers only ADRs that are traded on the NYSE, NASDAQ, and AMEX exchanges. Future research in this area my involve examining all dividends paid by ADRs, rather than just those coded as regular, quarterly cash dividends.

Using the data available, the analysis above implies differences in determinants of dividend level changes. The analysis shows dividend paying status, implied by the dividend policies of the firm within the previous twelve quarters, economic conditions, size, measured by total assets, growth opportunities, and profitability can determine whether a firm will change the dividend level of the firm.

Analysis of returns using the Fama-French two-factor model for international firms found that American Depository Receipts have significant negative abnormal returns. However, the R-squares of the Fama-French regressions showed a lack of fit, with the two-factor model only being able to predict about $8 \%$ of the variability in ADR returns. 


\section{CHAPTER 5: FINAL SUMMARY AND CONCLUSIONS}

\subsection{Summary of Empirical Findings}

This dissertation examines dividend payments in a manner not studied before. The objectives of this dissertation are: 1) to determine whether dividend payment history and the state of the U.S. economy can be used to predict dividend payment for U.S. companies, 2) to determine whether dividend payment history and the state of the U.S. economy can be used to predict changes in the dividend level of U.S. companies, 3) to determine whether changes in dividend payments of ADRs are affected by the dividend payment history of the firm and the home country's economic state, and finally, 4) to examine returns according to the dividend paying status of the firm.

In the second chapter of this dissertation we examine the probability of dividend payment for U.S. firms. The importance of a firm's dividend payment history and the economic situation are the determinants focused on in this study. Their contribution to the likelihood that a dividend will be paid is analyzed, while controlling for various determinants already identified in previous literature. We control for size, earned equity, growth opportunities, and profitability.

Status is a variable constructed within this dissertation to summarize the dividend payment history of a firm. The last twelve quarters of dividend distributions are employed to create this variable. If, within the past twelve quarters, a firm paid a dividend classified as a regular, quarterly, cash dividend by the CRSP database, then the firm is classified as a regular dividend paying firm. If the firm did not pay any dividends in the previous twelve quarters, the firm is classified as a non-dividend payer. However, 
if the firm occasionally paid dividends in the previous twelve quarters, the firm is identified as a switcher firm.

In order to evaluate economic conditions, we use three different measures: The first measure we use is the NBER's classifications of economic contractions and expansion. According to the NBER, economic contractions occurred from March 2001 through November 2001 and December 2007 through June 2009. In our study, we label these periods as economic recessions, and all other periods are classified as economic expansions. We also use the classic definition of GDP. If two consecutive quarterly declines in GDP occur, we classify the following period as an economic recession. All other periods are classified as economic expansions. Finally, we use the return on the S\&P 500 index to measure economic conditions.

Using a binary logisitic regression we find that, in fact, the firm's dividend payment history and the economic conditions at the time of the announcement are important factors in determining dividend payment. Whether the NBER classifications of economic contractions and expansions are used or the return on the S\&P 500 Index is used to measure economic conditions, logistic regressions find that including this effect in the model for determining dividend payment considerable improves the fit of the model. In other words, economic conditions have a discernable effect on dividend payment.

The third chapter of this dissertation examines dividend level changes of U.S. companies that trade on the NYSE, NASDAQ, and AMEX exchanges. The focus of this chapter is to determine whether dividend paying status and economic conditions affect dividend level changes. Firms are classified according to dividend paying status, as in 
Chapter 1. Economic conditions are measured using the NBER classifications for economic expansions and contractions.

Results of polytomous logistic regressions imply that dividend paying firms are most likely to change dividends. All firms are likely to adjust dividend payments during economic expansions, although increases are more likely than decreases.

Polytomous logistic regressions are also used to determine the probability of dividend changes of American Depository Receipts. In order to measure economic conditions in the home country we construct an effect called Economic Cycle. This effect is measured using gross domestic product (GDP), gross national income (GNI), industrial production, retail sales, and unemployment. If GDP, GNI, industrial production, and retail sales decline for two consecutive quarters, while unemployment increases, we classify the next quarter as a recession. All other periods are classified as economic expansions. Results of the polytomous logistic regressions imply that regular dividend paying ADRs are more likely to change dividend levels. Also, healthy economic conditions in the home country are more likely to induce changes in the dividend level.

Quarterly returns of all U.S. stocks, regular dividend paying stocks, non-dividend paying stocks, and switcher stocks are regressed against the three Fama-French factors. Fama-French three-factor regressions for reveal that regular dividend paying U.S. firms earn substantially higher abnormal returns, as compared to non-dividend paying firms and switcher firms. In order to examine returns on American Depository Receipts, the Fama-French two-factor model for international firms is employed. Two-factor regressions using returns for all ADRs, regular dividend paying ADRs, non-dividend 
paying ADRs, and switcher ADRs imply that all ADRs, regardless of their dividend paying status, earn significant negative returns.

This dissertation is important to investors holding dividend paying securities in their portfolios because the empirical results show that dividend payments are dependent upon the firm's dividend payment history and the current economic conditions. Firms are likely to continue according to the dividend payment patterns established within the previous twelve quarters. However, firms that are dividend payers, but can no longer sustain dividend payments are likely to discontinue dividend payments during relatively good economic conditions. In terms of dividend changes, more volatility is seen in payments of regular dividend paying firms. Also, good economic conditions are likely to bring about more volatility. Although firms are most likely to increase dividends during expansions, a decrease in dividends is still more likely than no change. Implications are similar for American Depository receipts.

Implications regarding the returns aspect of this dissertation are meaningful for investors who are concerned with the risk-return relationship. Returns of regular dividend paying firms are much higher than the returns of other firms with similar risk. This implies that dividend paying firms are excellent securities for risk-averse investors. On the other hand, American Depository Receipts earn negative abnormal returns. The returns on these securities do not compensate investors for the level of riskiness associated with ADRs.

\subsection{Limitations}

A limitation common to the study in Chapter 2 and the study in Chapter 3 is related to the classification of dividend paying status. We determined the status based on 
the firm's dividend payments in the previous twelve quarters. We concluded that based on its recent dividend paying patterns, the market would either identify it as a firm that regularly pays dividends, a firm that does not pay dividends at all, or a firm that pays dividends occasionally, but not regularly. This may classify a few firms incorrectly in some periods. For example, a firm that has never paid a dividend will be classified as a nonpayer. However, if that firm should pay a dividend the next period, then according to our classification, a nonpayer paid a dividend. In the next quarter, this firm would be classified as a switcher because it only paid one dividend in the past twelve quarters, even if it will continue as a regular dividend payer in the future. Although we have a few of these instances, for the most part, firms are classified correctly, as the market would identify them.

Another limitation is the lack of data available of American Depository Receipts. COMPUSTAT is limited to equity securities that trade on the NYSE, NASDAQ, and AMEX exchanges. Therefore, ADRs trading on other exchanges are not examined in this study.

The small number of regular, quarterly, cash dividend payments by American Depository Receipts compounds the data availability problem. This problem can be overcome by examining all cash distributions paid by ADRs. However, new limitations of the study will arise. Examining all types of dividends will complicate the study by possibly introducing multiple dividend payments in the same quarter. Other dividends, such as special dividends or monthly dividends tend to be in very different amounts than regular, quarterly dividends. This will also bring about more variability in the dividend 
change. The question of comparability is also introduced because the dividends have different classifications.

\subsection{Future Research}

Future research regarding dividend payment could focus on a distress variable. This would be of special interest during the recent financial crisis. Although there were only a few firms that omitted dividends, they were highlighted extensively in the financial news as distressed firms. Distress variables have been examined in the past in terms of the probability of bankruptcy. A similar approach can be used to determine dividend payment.

Dividend changes can also be examined in an event study where cumulative abnormal returns are calculated after the dividend announcement. This type of study would be similar to the event studies mentioned in the literature review in Chapter 3 . These types of studies are commonly used for examining tax impacts and dividend recapture of ex-dividend dates.

The study on American Depository receipts, in Chapter 4, can be conducted at a future date to obtain more conclusive results. American Depository Receipts have recently become a popular vehicle for international investment, and more and more international firms are becoming part of ADR programs. However, at the present time, data availability seems to be the greatest hindrance in making certain conclusions.

\subsection{Concluding Remarks}

The recent financial crisis highlighted changes in dividend payment policy. The financial news was filled with reports of dividend reductions, omissions, and suspensions. After examining various dividend related variables highlighted by previous literature, this 
study finds that dividend paying history, at least within the previous twelve quarters, is especially important in determining the probability that a firm will pay a regular, quarterly, cash dividend in the next quarter. The state of the economy is also important in determining dividend payment. Although the financial news highlighted changes in dividend downgrades during the recent recession, it is more likely that regular dividend paying firms will discontinue or omit dividends in good economic states.

Dividend paying history and the economic climate are also important for determining the probability of dividend level changes, whether the firm is a U.S. firm or an American Depository Receipt. Increases in total assets and profitability were related to an increase in the likelihood of a change in dividend levels, while increases in growth opportunities were related to the likelihood of a dividend decrease.

The study involving American Depository Receipts is limited by the few number of regular, quarterly, cash dividend payments, as well as limited data availability of key accounting data used for creating the dividend determinant measures.

Analysis of returns of U.S. stocks using the Fama-French three-factor model reveals that regular dividend paying firms have positive and significant abnormal returns, despite the fact that non-dividend payers have higher average returns. This implies that, on average, dividend paying stocks are earning more return for their level of risk. On the other hand, the Fama-French two-factor model for international firms reveals that all American Depository Receipts earn significant negative abnormal returns, regardless of their dividend paying status. However, the results for the ADRs are questionable due to the weaknesses mentioned above, and the fact that the R-squares for the Fama-French two-factor models are very low. 


\section{REFERENCES}

Asquith, P., \& Mullins, D. W. (1983). The Impact of Initiating Dividend Payments of Shareholders' Wealth. The Journal of Business , 56 (1), 77-96.

Baker, M., \& Wurgler, J. (2004). A Catering Theory of Dividends. The Journal of Finance, 59 (3), 1125-1165.

Bekaert, G., \& Urias, M. S. (1999). Is There a Free Lunch in Emerging Market Equities? The Journal of Portfolio Management , 25 (3), 83-95.

Benartzi, S., Michaely, R., \& Thaler, R. (1997). Do Changes in Dividends Signal the Future or the Past? The Journal of Finance , 52 (3), 1007-1034.

Black, F. (1976). Studies of Stock Market Volatility Changes. Proceedings of the American Statistical Association, Business and Economic Statistics Section, 177-181.

Boyd, J. H., \& Jagannathan, R. (1994). Ex-dividend price behavior of common stocks. The Review of Financial Studies , 7 (4), 711-741.

Brav, A., Graham, J. R., Harvey, C. R., \& Michaely, R. (2005). Payout policy in the 21st century. Journal of Financial Economics , 77, 483-527.

Campbell, J. A., \& Beranek, W. (1995). Stock Price Behavior on Ex-Dividend Dates. The Journal of Finance , 10 (4), 425-429.

Choi, Y. K., \& Kim, D.-s. (2000). Determinants of American Depository Receipts and their underlying stock returns-Implications for international diversification. International Review of Financial Analysis , 9 (4), 351-368.

DeAngelo, H., \& DeAngelo, L. (2006). The irrelevance of the MM dividend irrelevance theorem. Journal of Financial Economics , 79 (2), 293-315.

DeAngelo, H., DeAngelo, L., \& Skinner, D. J. (2004). Are dividends disappearing? Dividend concentration and the consolidation of earnings. Journal of Financial Economics , 72, 425-456.

DeAngelo, H., DeAngelo, L., \& Skinner, D. J. (1992). Dividends and Losses. The Journal of Finance , 47 (5), 1837-1863.

DeAngelo, H., DeAngelo, L., \& Skinner, D. J. (2000). Special dividends and the evolution of dividend signaling. Journal of Financial Economics , 57, 309-354.

DeAngelo, H., DeAngelo, L., \& Stulz, R. M. (2006). Dividend Policy and the earned/contributed capital mix: a test of the life-cycle theory. Journal of Financial Economics , 81 (2), 227-254. 
Denis, D. J., \& Osobov, I. (2008). Why do firms pay dividends? International evidence on the determinants of dividend policy. Journal of Financial Economics , 89 (1), 62-82.

Domowitz, I., Glen, J., \& Madhavan, A. (1998). International Cross-Listing and Order Flow Migration: Evidence from and Emerging market. Journal of Finance , 53 (6), 20012027.

Easterbrook, F. H. (1984). Two agency-cost explanations of dividends. American Economic Review , 74 (4), 650-659.

Elton, E. J., Gruber, M. J., \& Blake, C. R. (2005). Marginal Stockholder Tax Effects and Ex-Dividend Day Price Behavior: Evidence from Taxable Versus Nontaxable ClosedEnd Funds. The Review of Economics and Statistics, 87 (3), 579-586.

Fama, E. F., \& French, K. R. (1993). Common Risk Factors in the Returns on Stocks and Bonds. Journal of Financial Economics , 33 (1), 3-56.

Fama, E. F., \& French, K. R. (2001). Disappearing Dividends: Changing Firm Characteristics of Lower Propensity to Pay? The Journal of Finance, 60 (1), 3-43.

Fama, E. F., \& French, K. R. (2000). Forecasting Profitability and Earnings. Journal of Business , 73, 161-175.

Fama, E. F., \& French, K. R. (1998). Value versus Growth: The International Evidence. The Journal of Finance, 53 (6), 1975-1999.

Forester, S. R., \& Karolyi, G. A. (1998). Multi-Market Trading and Liquidity: A Transaction Data Analysis of Canada-U.S. Interlistings. Journal of International Financial Markets, Institutions, and Money, 8, 393-412.

Forester, S. R., \& Karolyi, G. A. (2000). The Long-run Performance of Global Equity Offerings. Journal of Financial and Quantitative Analysis , 35, 499-528.

French, K. R. (n.d.). Kenneth French: Data Library. Retrieved January 15, 2011, from http://mba.tuck.dartmouth.edu/pages/faculty/ken.french/data_library.html

Fuller, K., \& Blau, B. M. (2010). Signaling, Free Cash Flow and 'Nonmonotonic' Dividends. Financial Review , 45 (1), 21-55.

Gonedes, N. J. (1978). Corporate Signaling, External Accounting, and Capital Market Equilibrium: Evidence on Dividends, Income, and Extraordinary Items. Journal of Accounting Research , 16 (1), 26-79.

Gorman, L. R., Mahajan, A., \& Weigand, R. A. (2004). The ex-dividend day behavior of American depository receipts. Journal of Multinational Financial Management , 14 (1), $1-18$. 
Graham, J. R., Koski, J. L., \& Loewenstein, U. (2006). Information Flow and Liquidity around Anticipated and Unanticipated Dividend Announcements. The Journal of Business , 79 (5), 2301-2336.

Griffin, J. M., \& Karolyi, G. A. (1998). Another look at the role of the industrial structure of markets for international diversification strategies. Journal of Financial Economics , $50(3), 351-371$.

Grullon, G., Michaely, R., \& Swaminathan, B. (2002). Are Dividend Changes a Sign of Firm Maturity? The Journal of Business , 75 (3), 387-424.

Harvey, C. R. (1995). Predictable Risk and Returns in Emerging Markets. The Review of Financial Studeis , 8 (3), 773-816.

Hayn, C. (1995). The information content losses. Journal of Accounting and Economics, 20, 125-153.

Heston, S. L., \& Rouwenhorst, K. G. (1994). Does industrial structure explain the benefits of international diversification? Journal of Financial Economics , 36 (1), 3-27.

Jensen, M. (1986). Agency Costs of Free Cash Flow, Corporate Finance, and Takeovers. American Economic Review , 76, 323-329.

Jiang, C. X. (1998). Diversification with American Depositoty Receipts: The Dynamics and the Pricing Factors. Journal of Business Finance and Accounting , 25 (5-6), 683-699.

Karolyi, G. A. (2004). The Role of American Depositary Receipts in the Development of Emerging Equity Markets. The Review of Economics and Statistics , 86 (3), 670-690.

Koch, A. S., \& Sun, A. X. (2004). Dividend Changes and the Persistence of Past Earnings Changes. The Journal of Finance, 59 (5), 2093-2116.

La Porta, R., Lopez-de-Silanes, F., \& Vishny, R. W. (2000). Agency Problems and Dividend Policies around the World. The Journal of Finance , 55 (1).

La Porta, R., Lopez-de-Silanes, F., Shleifer, A., \& Vishny, R. (2000). Investor protection and corporate government. Journal of Financial Economics , 58 (1), 3-27.

Lee, B.-S. (1995). The Response of Stock Prices to Permanent and Temporary Shocks to Dividends. The Journal of Financial and Quantitative Analysis , 30 (1), 1-22.

Lee, B.-S. (1996). Time-Series Implications of aggregate Dividend Behavior. The Review of Financial Studies , 9 (2), 589-618.

Lessard, D. R. (1974). World, National, and Industry Factors in Equity Returns. The Journal of Finance , 29 (2), 379-391. 
Li, W., \& Lie, E. (2006). Dividend changes and catering incentives. Journal of Financial Economics , 80 (2), 293-308.

Lintner, J. (1956). Distribution of Incomes of Corporations Among Dividends, Retained Earnings, and Taxes. The American Economic Review , 46 (2), 97-113.

Miller, M. H., \& Modigliani, F. (1961). Dividend Policy, Growth, and the Valuation of Shares. The Journal of Business , 34 (4), 411-433.

Miller, M. H., \& Rock, K. (1985). Dividend Policy under Assymetric Information. The Journal of Finance , 40 (4), 1031-1051.

Modigliani, F., \& Miller, M. H. (1963). Corporate Income Taxes and the Cost of Capital: A Correction. The American Economic Review , 53 (3), 433-443.

Modigliani, F., \& Miller, M. H. (1958). The Cost of Capital, Corporation Finance and the Theory of Investment. The American Economic Review , 48 (3), 261-297.

Modigliani, F., \& Miller, M. H. (1959). The Cost of Capital, Corporation Finance, and the Theory of Investment: Reply. American Economic Review , 49, 655-669.

Moel, A. (2001). The role fo ADRs in the development of emerging markets. Economia .

Moel, A. (n.d.). The role of information disclosure on stock market listing decisions: the case of foreign firms listing in the U.S. Working Paper, Harvard University .

Nissim, D., \& Ziv, A. (2001). Dividend Changes and Future Profitability. The Journal of Finance, 56 (6), 2111-2133.

Opler, T., Pinkowitz, L., Stulz, R., \& Williamson, R. (1999). The determinants and implications of corporate cash holdings. Journal of Financial Economics , 52 (1), 3-46.

Parhizgari, A. M. (2011). Dividends, Taxes, and Global Financial Meltdown. Working Paper .

Patro, D. K. (2000). Return behavior and pricing of American depositary receipts.

Journal of International Financial Markets, Institutions and Money, 10 (1), 43-67.

Penman, S. H. (1983). The Predicitve Content of Earnings Forecasts and Dividends. The Journal of Finance , 38 (4), 1181-1199.

Roll, R. (1992). Industrial Structure and the Comparative Behavior of International Stock Market Indices. The Journal of Finance , 47 (1), 3-41.

Sheskin, D. J. (2007). Handbook of Parametric and Nonparametric Statistical Procedures (Fourth ed.). Boca Raton, FL: Chapman \& Hall/CRC. 
Skinner, D. J. (2008). The evolving relation between earnings, dividends, and stock repurchases. Journal of Financial Economics , 87 (3), 582-609.

The National Bureau of Economic Research. (n.d.). Retrieved from U.S. Economic Cycle Expansions and Contractions: http://www.nber.org/cycles.html

Watts, R. (1973). The Information Content of Dividends. The Journal of Business , 46 (2), 191-211.

Wright, R. E. (1995). Logistic Regression. In L. G. Grimm, \& P. R. Yarnold, Reading and Understanding Multivariate Statistics (pp. 245-276). Washington, D.C.: American Psychological Association. 


\section{APPENDIX}

\section{APPENDIX A}

\section{A PRIMER ON AMERICAN DEPOSITORY RECEIPTS}

American Depository Receipts, usually referred to as ADRs, represent ownership of shares of a foreign company. Investors tend to shy away from foreign stocks because of the risks and costs associated with buying and selling foreign securities. ADRs eliminate some of those obstacles. They are convenient for U.S. investors because they are priced in U.S. Dollars, pay dividends in U.S. Dollars, and trade like U.S. shares. However, foreign exchange risk still exists because the price of the security tracks the price of the foreign stock it is derived from.

ADRs are issue by U.S. depository banks. At the present time, there are five of depository banks: JPMorgan, Citibank, Deutsche Bank, the Bank of New York Mellon, and the Computershare Trust Company of New York. The shares issued by these banks can represent a share, a fraction of a share, or multiple shares of the foreign firm. An investor who owns an ADR can also choose to obtain the foreign stock, but it is more convenient to hold an ADR.

There are different levels of ADR firms, which determine their regulations and characteristics. An unsponsored ADR is one that trades on over-the-counter markets. The foreign firm has no formal agreement with a depository bank. These are the least regulated. Therefore, most ADRs are unsponsored. A Level I ADR is also an over-thecounter ADR, but the foreign firm has a formal agreement with a depository bank to act as its transfer agent. Regulations and reporting are also minimal for Level I ADRs. 
A Level II ADR requires far more regulation than Level I because these are traded on exchanges. They fall under SEC regulation and must file annual reports and follow Generally Accepted Accounting Principles or International Financial Reporting Standards. A Level III ADR is also heavily regulated because these types of ADRs are traded on exchanges and are able to issue shares to raise new capital within the U.S.

Dividend payments of ADRs can be inconvenient for U.S. investors because of the regulations and procedures involved. Dividend payments are issued by the foreign firm in the foreign currency. They then have to be converted to U.S. Dollars. The amount a U.S. investor receives is less than the actual dividend paid because conversion expenses and foreign taxes must be paid. Withholding tax is also a problem in some instances, but it may be recoverable on U.S. tax filings. 
VITA

GIZELLE FERNANDEZ PERRETTI

February 29, 1984

2005

2006
Born, Miami, Florida

B.S., Finance

Florida State University

Tallahassee, Florida

M.S., Economics

Florida State University

Tallahassee, Florida

Planning and Research

Economist

Florida Department of Revenue

Tallahassee, FL

Graduate Teaching Assistant

Florida International University

Miami, Florida

\section{PUBLICATIONS AND PRESENTATIONS}

Perretti, G.F., Parhizgari, A.M, (April 2010). Returns on the US Dividend Paying, Non-dividend Paying, and Switchers Firms. Paper presented at the Eastern Finance Association Conference, Miami Beach, Florida

Perretti, G.F., Hamid, S.H., (April 2011). Effect on Option Trading Volume When Equity Short Sale Restrictions are Imposed or Removed. Paper presented at the Southern Finance Association Conference, Asheville, NC and at the Eastern Finance Association Conference, Savannah, Georgia 